\title{
O CONCEITO DE PESSOA NA PERSPECTIVA DA BIOÉTICA SECULAR: UMA PROPOSTA \\ A PARTIR DO PENSAMENTO DE TRISTRAM ENGELHARDT
}

\section{CLÉA REGINA DE OLIVEIRA RIBEIRO}

Tese de Doutorado apresentada ao Departamento de Prática de Saúde Pública da Faculdade de Saúde Pública da Universidade de São

Paulo para obtenção do Grau de Doutor.

Área de Concentração: Serviços de Saúde Pública - Ética

Orientador: PROF. DR. MARCO SEGRE 


\section{AGRADECIMENTOS}

Ao Prof. Dr. Marco Segre, meu orientador, agradeço sinceramente por compartilhar seus conhecimentos e sua grande experiência em Bioética ao aceitar orientar esta tese, já que sua atuação se faz na Faculdade de Medicina da Universidade de São Paulo. Sua vocação livre para a filosofia e sua generosidade possibilitaram meu crescimento na área de Bioética, para a qual estão concentrados todos os esforços de investigação deste trabalho.

Ao Prof. Dr. Paulo Antonio de Carvalho Fortes, por me acolher na área de Ética (Serviços de Saúde Pública) do Programa de Doutorado da Faculdade de Saúde Pública da Universidade de São Paulo; e sobretudo pelas discussões enriquecedoras sobre ética, bioética, saúde e filosofia.

A Profa. Dra. Carmen Cinira Santos Martin, da Faculdade de Medicina de Ribeirão Preto da Universidade de São Paulo, pelas primeiras lições de Bioética, e, por me introduzir como um neófito nas questões de saúde e da ética da vida e da morte.

Ao Prof. Dr. João de Fernandes Teixeira, da Universidade Federal de São Carlos, por me aguçar a curiosidade filosófica inicial pela Bioética.

Aos colegas do Departamento de Enfermagem Psiquiátrica e Ciências Humanas da Escola de Enfermagem de Ribeirão Preto da Universidade de São Paulo, especialmente a Profa. Dra. Antonia Regina Ferreira Furegato, Profa. Dra. Maria Alice Ornellas Pereira, Profa. Dra. Maria Cecilia Morais Scatena, Profa. Dra. Renata Curi Labate e Profa. Dra. Maria Cristina Silva Costa pelo incentivo e 
encorajamento durante $\circ$ processo de desenvolvimento desse trabalho.

Aos alunos da EERP/USP, especialmente d̀ $44^{\circ}$ Turma de Formandos de 2000, que me honrou profundamente com o tífulo de Paraninfa; agradeço pela postura atenta e autêntico interesse nas discussões de Ética e Bioética, me proporcionando, desse modo, a oportunidade de colocar as sementes de uma consciência profissional e humana em seus coraçōes, sobretudo a do respeito, da autonomia, da responsabilidade, da solidariedade e da seriedade.

À minha família pelo apoio irrestrito; especialmente à $D$. Adelina, minha mãe, pela força da esperança. A meu pai, enquanto esteve vivo, pela confiança. 
Dedico este trabalho a meu pai, Gervásio de Oliveira Ribeiro, in memoriam. 


\section{RESUMO}

Ribeiro $C R O, O$ conceito de pessoa na perspectiva da bioética secular: uma proposta a partir do pensamento de Tristram Engelhardt. São Paulo; 2002. [Tese de Doutorado - Faculdade de Saúde Pública da USP].

A fundamentação filosófica do conceito de pessoa para a Bioética, área de estudos interdisciplinares, é imprescindível para o resgate da importância da Ética na área da Saúde.

Esta investigação teórica, de cunho crítico-reflexivo, se desenvolve em torno do pensamento de Tristram Engelhardt, tendo como pressupostos o Humanismo e o Secularismo, originados na modernidade, como panorama para a ética contemporânea pluralista.

Os dois conceitos de pessoa, em sentido estrito e em sentido social, estabelecem a diferença entre vida biológica humana e vida humana pessoal, apresentando as características de autoconsciência e racionalidade para imputabilidade moral.

A categoria de estranhos morais, decorrente do conceito de pessoa em sentido estrito, desencadeia a discussão dos princípios de autonomia e de consentimento, tendo em vista o acordo mútuo entre pessoas frente à diversidade moral nas situações de dilemas éticos na assistência à saúde.

Sucintamente se apresenta a proposta existencialista sartreana como um forma de reflexão sobre a questão da consciência e a da liberdade.

Finalmente, ressalta-se a contribuição teórica do filósofo e médico Engelhardt para a Bioética que, mesmo em meio a outros modelos da ética aplicada, sua concepção de pessoa constitui uma ferramenta útil nas questões de pertinência ética, frente aos 
desenvolvimentos das ciências biomédicas, e também para 0 equacionamento do papel do sujeito moral. Apresenta-se, brevemente, duas concepções de responsabilidade (Jonas e Lévinas), pois a questão da responsabilidade surge subjacente às idéias de permissão em Engelhardt e de liberdade em Sartre.

Descritores: Bioética secular. Pessoa. Autonomia. Indivíduo, responsabilidade. 


\section{SUMMARY}

Ribeiro CRO, O conceiło de pessoa na perspectiva da bioética secular: uma proposta a partir do pensamento de Tristram Engelhardt. [The Concept of Person according to secular bioethics perspective: a proposal based on Tristram Engelhardt thought]. São Paulo (BR); 2002. [Tese de Doutorado - Faculdade de Saúde Pública da USP].

The philosophical basis of the concept of Person for Bioethics, an area of interdisciplinary studies, is essential for the recovery of the importance of Ethics in the health care field.

This theoretical, critical and reflective investigation is developed on basis of Tristram Engelhardt's thoughts by using the assumptions of Humanism and Secularism, which originated in modernity as an outline for the pluralist contemporary ethics.

The two concepts of Person, in strict sense and social sense, establish a difference between human biological life and human personal life by presenting the characteristics of self-conscience and rationality for moral imputability.

The category of moral strangers stemming from the concept of person in strict sense triggers the discussion concerning the principles of autonomy and consent, aiming at the mutual agreement between people in face of moral diversity in situations involving ethical dilemmas in health care.

The Sartrean existentialist proposal is briefly presented as a form of reflection concerning the question of conscience.

Finally, the theoretical contribution given by philosopher and physician Engelhardt to Bioethics is emphasized. Among other models of applied ethics, his conception of person constitutes a useful tool in questions of ethical relevance in face of the development in biomedical sciences as well as for the clarification of the moral 
subject's role. A very brief exposition of Jonas and Lévinas 's principle of responsability is presented; responsability originated from the notion of permission in Engelhardt and freedom in Sartre.

Descriptors: Secular bioethics. Personhood. Autonomy. Individual, responsabilitiy. 


\section{ÍNDICE}

I-INTRODUÇÃO.

II - BIOÉTICA SECULAR: PRESSUPOSTOS............................................ 19

1.Crítica à Ética Essencial e a falência do Projeto lluminista............ 19

1.1.Ética Essencial e Moral Canônica................................................ 20

1.2.Falência do Projeto lluminista..................................................... 26

2.Humanismo, Secularismo, Pluralismo ............................................... $\quad 30$

2.1. Humanismo ...........................................................................

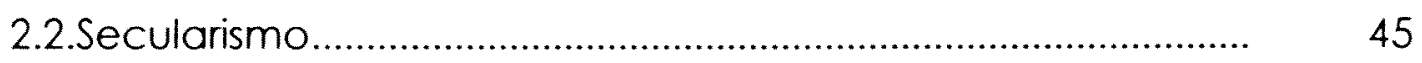

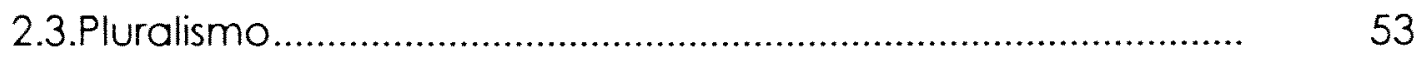

2.3.1.Pluralismo não é UniversalismoMoral....................................... 56

2.3.2.Pluralismo não é Ecumenismo................................................... 57

III - A CONCEPÇÃO DE PESSOA PARA ENGELHARDT....................... 63

1.Consideraçōes Histórico-filosóficas do Conceito de Pessoa......... 63

2.Estar Vivo e Ser Pessoa: Diferença fundamental.............................. 67

3.Kant e Engelhardt: a Distinção entre Coisa e Pessoa e a Distinção entre Pessoa e Não-Pessoa.................................................. 69

4.Dois Conceitos de Pessoa em Engelhadt....................................... 74

4.1.Pessoa em Sentido Estrito............................................................. $\quad 75$

4.2.Pessoa em Sentido Social .......................................................... $\quad 77$

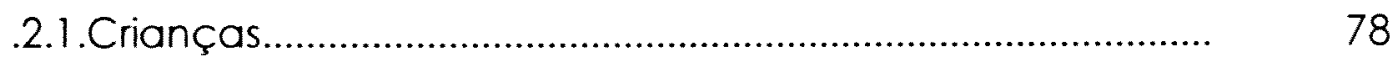

4.2.2.Idosos e Doença Mental.......................................................... $\quad 80$

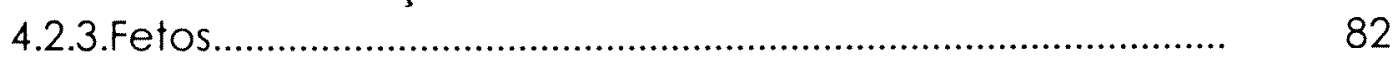

5.Amigos Morais e Estranhos Morais................................................. 84

5.1.Assistência à saúde, secularismo e bioética............................... 88

6.Vida: Valor e Dignidade............................................................... 92

IV - AUTONOMIA E CONSCIÊNCIA: ALGUMAS QUESTÕES 95

1.Autonomia como consentimento: Engelhardt............................... 95

2.Autonomia: visão crítica sob o horizonte psicanalítico.................... 104

2.1.Busca da Autonomia: entre as Emoçōes e a decisão................ 106

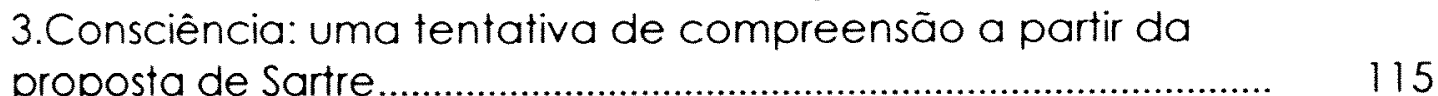

3.1. Responsabilidade e liberdade................................................. 126

3.2.Sartre e Engelhardt....................................................................... 129

V - CONSIDERAÇŌES FINAIS......................................................... 132

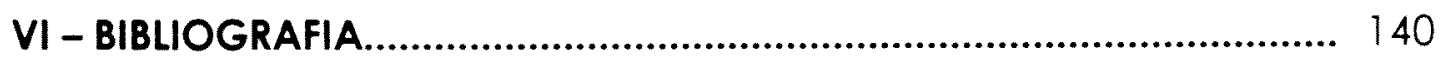

ANEXO: A Produçāo intelectual de Engelhardt................................. Al 


\title{
I- INTRODUÇÃO
}

\author{
Quem habita este planeta não é o \\ Homem, \\ Mas os homens. \\ A pluralidade é a lei da Terra. \\ H. ARENDT
}

Este trabalho de pesquisa propōe o estudo de alguns dos fundamentos filosóficos do discurso bioético, e como tal se constitui em uma investigação teórica de cunho crítico-reflexivo.

A Filosofia, enquanto produção de conhecimento, caracterizase por ser uma área essencialmente teórica voltada para o desenvolvimento de uma articulação de conceitos e sistemas de pensamento com o objetivo de problematizar, criticar, propor e ampliar a reflexão acerca dos vários temas aos quais ela se dedica. A Ética, como um dos ramos da Filosofia, também guarda tais particularidades. Com a recente emergência de uma subárea desta disciplina filosófica, a bioética, aparece um fato novo que vem se somar à sua caracterização original: a sua especificidade como ética prática ou ética aplicada. Inaugura-se, assim, uma área de reflexão voltada também para a produção conceitual, mas com um olhar dirigido a uma certa praxis, no intuito de realizar esta reflexão e 
propor teorias que se refiram a um horizonte identificado de vivências e práticas.

É no contexto acima que se insere a bioética_ética da vida_ como uma área preocupada em estudar os valores, os princípios, os sistemas morais e éticos que subsidiam a formação e a emissão de juízos sobre a conduta e o comportamento concernentes às várias instâncias da vida e da natureza como um todo: dos humanos, dos animais, do planeta.

A bioética surge nos EUA na década de 70.

O termo 'bioética' é um neologismo e foi inventado pelo oncologista Van Rensslaer em seu livro Bioethics: bridge to the future, de 1971. Segundo MORI (1994), a preocupação do autor era chamar atenção para a relação destrutiva e devastadora que o homem acabou estabelecendo com a natureza. Diante de tal situação, para Potter, a relação intuitiva que o homem sempre manteve com a natureza deveria ser substituida por uma relação ética /valorativa e normativa); essa nova postura, que ele denominou "bioética", teria como base a biologia e se constituiria em uma "nova ética científica que tem por objetivo garantir a sobrevivência humana e a qualidade de vida" (p.334). 
Mas a bioética, tal como a entendemos na atualidade. adquiriu um outro significado, reconhecido pelo próprio Potter ', que foi se constituindo diferenciado, através da emergência de grupos e centros de estudos interdisciplinares preocupados com os novos desenvolvimentos científicos e os limites de aplicação da tecnologia no que diz respeito à vida humana. Um deles foi o Kennedy Institute (Georgetown University, Washington), fundado em 1971 pelo obstetra e fisiologista André Hellengers, que considerava a bioétca não "uma ética científica, mas a ética aplicada a um novo campo de estudo, o campo médico e biológico" (MORI 1994, p.335).

Na mesma época, em 1969, dois americanos, o filósofo Daniel Callaham e o psiquiatra Williard Gayling, preocupados também com a mesma questão, formam um grupo de estudos interdisciplinares composto por pesquisadores da área da saúde, sociólogos, filósofos, teólogos, assistentes sociais, entre outros. Entendiam que, como a questão apresentava vários aspectos, se fazia necessária uma colaboração especializada e diversificada, gerando uma discussão aprofundada e enriquecedora pela possibilidade da abordagem multidisciplinar de uma mesma questão ou problema. Tal iniciativa deu origem ao Institute of Society, Ethics and the Life Sciences,

\footnotetext{
1 Segundo MORI (1994 p.341, nota4) Potter em outro livro, Global bioethics - building on the Leopold legacy, caracteriza o sentido original de bioética como 'bioética global' diante das significações outras que o termo acabou adquirindo.
} 
conhecido como Hastings Center, New York, dirigido até hoje por Daniel Callahan.

Embora a bioética, enquanto área de estudos, abrigue tendências diversas e propostas de fundamentação diversificadas (aliás, o que é imprescindivel para fomentar o desenvolvimento da discussão e da reflexão sobre questões relacionadas à vida), segundo MORI (1994, p.334), depois de passada a "fase carismática" é possivel refletir e perceber a expansão da bioética. Mesmo não sendo possivel desenvolver esta análise aqui, pode ser dito, de acordo com o filósofo italiano, que na atualidade, praticamente todos os países tem pelo menos um grupo ou centro de estudos em bioética. Para Mori "durante os anos 70 o movimento se desenvolveu com uma rapidez surpreendente nos EUA; durante os anos 80 , alastrou-se às vezes com dificuldade, a muitos países europeus, tornando-se, nos anos 90, um fenômeno mundial e planetário, como mostrou a criação e a vitalidade da International Association of Bioethics $(\mid A B) "$.

A preocupação com a ética aplicada à vida e à saúde traz a questão de quais modelos éticos podem ser tomados como referenciais para fundamentação do juizo e da reflexão ética. Várias propostas emergem como modelos de pensar uma ética para a bioética; dentre essas várias linhas, algumas são resumidas abaixo: 
Modelo Principialialista: é a teoria de Tom Beauchamps \& James Childress, a partir da obra clássica Principles of biomedical ethics. Propõe a utilização dos princípios de autonomia, beneficência, não-maleficência e justiça como guias para ação, normas, julgamento e decisão ética. São utilizados prima facie, ou seja, a escolha e aplicabilidade do princípio será de acordo com a situação em questão (PESSINI \& BARCHIFONTAINE 1997, p.34).

Modelo Libertário: refere-se à proposta de Tristram Engelhardt e às idéias de estranhos morais, bioética e moral secular, consenso moral, esboçadas principalmente em Fundamentos de bioética (1986). Embora o autor rejeite a denominação "libertária" em relação a sua reflexão em bioética², esta the foi atribuída pela ênfase dada ao respeito pela autonomia do sujeito _ interpretada por muitos como uma apologia de liberdade incondicional do sujeito (PESSINI \& BARCHIFONTAINE 1997, p.34).

Modelo das Virtudes: proposta por Edmund Pellegrino e David Thomasma em For the patient's good. Embasa-se na teoria aristotélica das virtudes colocando enfatizando a educação para a prática da do Bem (a virtude suprema) nas ações de saúde, principalmente no exercício dos profissionais (PESSINI \& BARCHIFONTAINE 1997, p.35).

Modelo Casuístico: defendido por Albert Jonsen e Sefen Toulmin em The abuse of casuistry. De tendência intuicionista, prevê que

?. Ver Foundations of christian bioethics, 2000 
cada caso seja analisado com base em anteriores, sem quaisquer princípios fundamentais para a decisão ou ação. Assemelha-se à pratica da análise direła de casos em medicina clínica. Opõe-se diametralmente do principialismo (PESSINI \& BARCHIFONTAINE 1997, p.35).

Modelo do cuidado: originalmente baseado na obra In a different volce, de Carol Gilligan; o ponto de partida é a premissa de que as mulheres, por terem uma psicologia diferente dos homens, conseguem ter uma compreensão maior da moralidade. Percebem melhor a responsabilidade e praticam com mais veemência a solicitude em relação ao outro. Tal proposta posiciona-se contra a tendência universalizante e racionalista da ética dos princípios, ressaltando a importância das emoções e dos sentimentos nas decisões morais. Alguns também o denominam Modelo Feminista (CALLAHAN 1995, p.247).

Modelo Antropológico Personalista: é o mais abrangente nos países europeus. Propõe que a fundamentação antropológica seja a base da ação moral e das decisões, que dizer, que compreender a natureza do homem, suas dimensões e o contexto em que se insere é anterior em relação ao estabelecimento de qualquer princípio ético. (PESSINI \& BARCHIFONTAINE 1997, p.37-38).

Modelo Fenomenológico e Hermenêutico: Ambos defendem que toda experiência está sujeita à interpretação, que sempre 
existem duas posiçōes em cada situação. A defesa da perspectiva intersubjetiva e da participativa mostram que os significados gerados nos relacionamentos e no compartilhamento entre sujeitos rejeita a relação dualista bipolar (PESSINI \& BARCHIFONTAINE 1997, p.35-36).

Queremos esclarecer que existem outras perspectivas no que diz respeito a teorias éticas que fundamentam a reflexão ética, e, mesmo no interior de cada modelo existem variações e outros autores. Procedemos somente a uma visāo sintética do assunto.

Hugo Tristram Engelhardt Jr. insere-se no cenário da bioética americana. Conforme uma retrospectiva da vida de Tristram Engelhardt, escrita por Laurence B. McCullough, ex-aluno e atual colega, (MINOGUE 1997, p.XI-XIX), Engelhardt nasceu em 1941 na cidade de New Orleans, nos Estados Unidos. Possui uma formação pouco ortodoxa e linear, acumulando conhecimentos nas áreas de ciências humanas e ciências biomédicas. Bacharelou-se em Zoologia em 1963 e, enquanto esperava para cursar o Ph.D. em Filosofia ingressou na Tulane School of Medicine, interrompendo este curso de graduação para fazer o doutorado em Austin, o qual conclui em 1969. Depois disso voltou a cursar Medicina e recebeu seu diploma de médico com louvor, em 1972. Depois de ter estudado com Klaus Hartmann como doutorando, esteve como bolsista Fulbright na Universidade de Bonn, junto ao mesmo filósofo. 
Foi professor de Filosofia da Medicina no Kennedy Institute of Ethics (Georgetown University) de 1977 a 1982. Desde 1983 até a atualidade, é professor do Departamento de Filosofia na Rice University, professor do Departamento de Medicina e membro do Centro de Ética Médica e Políticas de Saúde do Baylor College of Medicine (Texas), ensinando e pesquisando nas áreas de Ética Médica, Filosofia da Medicina, Bioética e Ginecologia e Obstetrícia. Engelhardt, desde 1985 até a atualidade, acumula a função de editor do prestigiado periódico The Journal of Medicine and Philosophy, com circulação em mais de sessenta países.

É considerado uma das figuras internacionais mais proeminentes em Bioética e Filosofia da Medicina. Sua obra mais conhecida The Foundations of Bioethics foi lançada em $1^{\circ}$ edição em 1986 e a $2^{\circ}$ edição, de 1996, foi traduzida para o português, chinês, japonês, italiano e espanhol.

\section{O BRASIL E A BIOÉTICA}

Alastair Campbell, em 1998, recém-eleito presidente da IAB, na ocasião de sua participação no $\|$ Congresso Brasileiro Brasileiro de Bioética (Brasília), de passagem em São Paulo para uma conferência, escreve suas impressões sobre a bioética no Brasil:

Quando deixei o Brasil naquela visita tão curta, fiquei como sentimento de gratidāo para com os meus hospedeiros, nāo apenas por sua amizade e hospitalidade exemplar, mas 
pela conscientização do quão diferentemente eu agora percebia a natureza da Bioética. Tive uma rápida visão do quāo dificil deve ser sustentar um serviço de saúde pública com o mínimo de recursos e problemas maciços de pobreza. Vi algo do desafio ambiental provocado pela urbanização massiva, sem uma adequada infra-estrutura para sustentá-la. Nesse meio, encontrei pessoas determinadas a encontrar uma Bioética que faça uma genuina diferença para a saúde de sua naçāo e para a qualidade de seu desenvolvimento. (GARRAFA \& COSTA 2000, p. 39)

De acordo com apresentação ${ }^{3}$ feita no IV World Congress of the International Association of Bioethics, em 1998, em Tókyo, a bioética surge e começa a se constituir no Brasil, enquanto área de interesse em pesquisa, na década de 90 . Segundo DINIZ, GULHEM \& GARRAFA (1999), a consolidação da Bioética em nosso país se deu a partir de três marcos importantes e decisivos: a criação do primeiro periódico especializado na área, a fundação da Sociedade Brasileira de Bioética (SBB) e a Resolução 196/96 da CONEP.

Bioética, periódico editado pelo Conselho Federal de Medicina (CFM), iniciou publicação em 1993; é semestral e traz simpósios temáticos contemplando discussões sobre temas clássicos da área como aborto, eutanásia, reprodução assistida, alocação de recursos em saúde, autonomia e outros. Reúne em suas discussões artigos de bioeticistas brasileiros e internacionais.

A fundação da SBB, em 1995, teve o objetivo de reunir os pesquisadores e difundir a Bioética no país. Houve no início, na SBB,

\footnotetext{
${ }^{3}$.Diniz, Guilhem \& Garrafa. "Bioéthics in Brasil", Bioethics 1999 july; 12(3/4):245-248.
} 
uma presença forte de profissionais da área médica vinculados à discussão de questões éticas da medicina e de bioética, (característica não só brasileira), embora ałualmente já exista uma mescla de outros profissionais que trabalham na área da saúde e que se preocupam com o desenvolvimento da bioética voltado para os mais variados problemas e para outras áreas que não a ética na medicina.

Em 1996, foi estabelecida pelo Conselho Nacional de Saúde (CNS), do Ministério da Saúde, a RESOLUÇĀO 196/96 - Sobre pesquisa envolvendo seres humanos, que além de normatizar as pesquisas, criou a Comissão Nacional de Ética em Pesquisa (CONEP) e a regulamentação para o estabelecimento dos Comitês de Ética em Pesquisa (CEPs), de caráter institucional (hospitais, centros de pesquisa e universidades), com o intuito de avaliar a pertinência ética de pesquisas a serem desenvolvidas envolvendo seres humanos. A fundamentação desta Resolução baseia-se no principialismo (BEAUCHAMPS \& CHILDRESS 1989) com ênfase no princípio de autonomia, demonstrado pela obrigatoriedade do Consentimento livre e esclarecido para os sujeitos de pesquisa, no intuito de defender a dignidade e o respeito ao ser humano.

Estes três passos foram fundamentais para que a bioética no Brasil fosse estruturada e sua importância fosse reconhecida na formação dos profissionais de saúde. A legitimação da bioética no Brasil 
permitiu que sua introdução enquanto disciplina fizesse parte do curriculum de graduação e pós-graduação lado a lado com a Ética nos cursos universitários da área da Saúde, principalmente Medicina e Enfermagem. A formação de vários centros de pesquisa, o que também vêm contribuindo para a estruturação da bioética no Brasil; muitos destes estes núcleos de estudos se dedicam ao desenvolvimento de pesquisas em torno de temas específicos, incrementando cada vez mais a produção na área.

Para DINIZ, GUILHEM \& GARRAFA (1999, p.248), embora O paradigma dominante no Brasil ainda seja o principialista, é preciso constar que muitos pesquisadores se utilizam de outras linhas, outros enfoques e outros pressupostos fundamentais, tomando como base em suas reflexões, por exemplo, as idéias de autores europeus como Giovanni Berlinger, Diego Gracia, Maurizio Mori, dentre outros. ${ }^{4}$

\section{A PROPOSTA DE PESQUISA}

A proposta deste trabalho de pesquisa inscreve-se como um desenvolvimento de estudos na área da bioética, mas com uma preocupação voltada especificamente para as possibilidades de sua

\footnotetext{
${ }^{4}$.Ver PESSINI \& BARCHIFONTAINE (1996): "O desenvolvimento da bioética na América Latina".
} 
fundamentação.

Retrospectivamente, ao examinar as muitas publicações em bioética nas últimas décadas, percebe-se que houve uma exaustiva (e considero necessária) tendência para a discussão de questões voltadas a casos clínicos, dos quais muitos temas tiveram sua origem nas situações que envolviam dilemas éticos, congregando profissionais (médicos, enfermeiros), familiares e instituições _ temas como o aborto, a eutanásia, engenharia genética, doação de órgãos, alocação de recursos na saúde e outros. Mas há uma vasta região pouco explorada, do ponto de vista da perspectiva filosófica da bioética, que é justamente o aprofundamento da teoria ética subjacente aos debates sobre a perspectiva prática da bioética. É este conhecimento _ o da fundamentação ético-filosófica _ absolutamente necessário como pressuposto da reflexão bioética que necessita ser também desenvolvido para que, juntamente com os estudos de caso, a bioética se torne realmente uma ética verdadeiramente preocupada com a questão da vida, em todos os seus aspectos.

A noção de pessoa tem adquirido cada vez mais importância no cenário filosófico contemporâneo, cortando ortogonalmente vários temas da filosofia contemporânea, passando pela ética, pela filosofia moral e pela filosofia da mente. Contudo, apesar das discussões em torno deste tema poderem ser datadas à época 
medieval, é a partir da filosofia moderna que encontramos um rico desenvolvimento temático sobre pessoa. Na atualidade, o personalismo se destaca na discussão das questões referentes à ética aplicada, trazendo o conceito de pessoa como subjacente a qualquer tema de ética ou de bioética.

Constitui-se tema de nosso trabalho o conceito de pessoa, enquanto noção fundamental do discurso bioético. A idéia de pessoa, sua delimitação conceitual através do pensamento de Engelhardt, é o núcleo de nosso estudo.

De modo geral, o discurso bioético, nos últimos anos, apresenta um movimento pendular, ora oscilando para os excessos do utilitarismo e pragmatismo, ora em direção a uma restauração de uma bioética tradicional que tem como base o princípio da santidade da vida.

Várias alternativas a estes dois pólos estão surgindo, e uma a ser destacada, inclusive por seu aspecto polêmico, é a proposta de Engelhardt do humanismo secular, na qual se verifica o esforço de elaboração de uma bioética secular pluralista, sem, entretanto, cair nos exageros do utilitarismo ou da ética naturalizada. Uma das noções basilares desta teoria é a de pessoa (pessoa em sentido estrito e em sentido social) que justifica a idéia de estranhos morais, enquanto categoria fundamental para se pensar a viabilidade do consenso nas situações inconciliáveis de diversidade de valores que 
surgem nas questões de assistência à saúde. A fundamentação de pessoa, do ponto de vista filosófico, vem sendo buscada e, como o próprio autor comenta em várias passagens de seus textos, está longe de ser alcançada.

Diante desse panorama, o pensamento de Engelhardt se direciona para a rediscussão da identidade tradicional entre ser humano (vida biológica humana) e pessoa (vida humana pessoal); tendo como ponto de partida que se trata de categorias diferenciáveis _ e é com base nesta perspectiva que pretendemos desenvolver o núcleo de nossa discussāo.

Nossa investigação, portanto, se desenvolverá em torno do problema da identidade entre a concepção de pessoa e a concepção de ser humano, tendo como pressuposto a dificuldade em que tal identidade se assenta, na medida em que se torna questionável tal identificação. As questões atuais levantadas pela bioética, as quais se deparam com situações de pesquisa e de fato nas ciências biológicas, conduzem, de maneira crescente, à consideração do estado biológico como diferenciado do fato mental e psicológico frente ao estatuto do ser humano _ suscitando uma reformulação na maneira de se refletir sobre estas concepções.

$\mathrm{Na}$ diferenciação entre os dois conceitos de pessoa para Engelhardt, surgem alguns desdobramentos conceituais sobre os quais pretendemos fazer uma reflexão num segundo momento desta 
pesquisa: a questão da consciência _ que surge através da idéia de autoconsciência _ e a questão da autonomia _ através da idéia de pessoa, enquanto sujeito moral capaz de acordar, discordar, optar, recusar.

\section{OBJETIVOS:}

Assim sendo, os objetivos da investigação são:

1. Examinar a proposta de concepção de Pessoa para Engelhardt, a partir da questão da identidade entre ser humano e pessoa.

2. Analisar a distinção e o significado entre vida biológica e vida pessoal, tendo como pressupostos as categorias engelhardteanas de autoconsciência e Racionalidade.

3. Desenvolver uma reflexão crítica em torno das noções de consciência e autonomia.

Este estudo consta de seis capítulos, sendo que três são nucleares (capítulos II, III e IV) em termos do desenvolvimento do assunto proposto propriamente dito.

O capítulo I, como introdução, apresenta em que sentido a filosofia se relaciona à bioética, além recapitular alguns momentos da origem e da situação da bioética no Brasil, segundo a perspectiva de 
D. Diniz, D. Bellezi e V. Garrafa; fornece ainda, alguns dados sobre T. Engelhardt e a proposta e objetivos da investigação.

O capítulo Il apresenta os pressupostos com os quais Engelhardt assenta a concepção de Pessoa: um deles é a falência do paradigma do iluminismo e a impossibilidade de se pensar uma ética que tenha uma essência (no caso a Razão) ou que seja um modelo dominante essencial para a ação moral em nossa época. Os outros pressupostos são as concepções de humanismo, secularismo e pluralismo, como sendo o solo para a constituição de uma bioética secular desvinculada de uma moralidade particular. O autor faz esta reflexão referindo-se a questões ou problemas concretos na área da saúde.

O capítulo III apresenta a concepção engelhardteana de pessoa através do desdobramento dos conceitos de pessoa em sentido estrito e pessoa em sentido social, e as noções de amigos e estranhos morais.

O capítulo IV faz uma reflexão sobre conceitos decorrentes da fundamentação de pessoa: autonomia e consciência. Para Engelhardt o princípio de autonomia é entendido como princípio de permissão ou de consentimento. Incluímos uma visão crítica de autonomia baseada em categorias psicanalíticas. O tema da consciência será tratado sob a visão existencialista sartreana como uma das propostas contemporâneas de abordagem da consciência. 
Esta forma de reflexão neste capítulo tem $\circ$ objetivo de contribuir para ampliar o debate em torno destas noções.

O capítulo $\vee$, como considerações finais, procura mostrar $\circ$ ponto de chegada da reflexão proposta. Aponta a noção de responsabilidade como um princípio que se sobressai como conseqüente da argumentação desenvolvida no decorrer do trabalho em torno de Engelhardt e Sartre.

O capítulo VI intitulado Bibliografia, apresenta em primeiro lugar, as referências bibliográficas completas tanto das citações feitas no texto da tese como também das notas de rodapé; em segundo lugar, a bibliografia complementar contêm obras lidas, consultadas e aquelas para aprofundamento de temas paralelos mas vinculados de alguma maneira à nossa discussão.

Na última parte, em anexo, reproduzimos uma compilação das obras de Tristram Engelhardt, retirada de um livro que registra as comunicações e conferências de um encontro americano realizado em 1997 para discutir sua obra. Completamos com as publicações atuais do autor; tivemos o intuito de apresentar a extensão da produção intelectual do autor na área de saúde e, em especial, em bioética .

Finalizando, uma advertência de ordem formal: todas as citaçōes textuais, escritas em português, da obra de Engelhardt, com exceção de fundamentos de bloétlca (edição brasileira de 1998). 
são de nossa responsabilidade, no que diz respeito à tradução, já que Fundamentos é o único livro traduzido para o português. Nossas traduções foram feitas a partir das obras originais em inglês. 


\section{II - BIOÉTICA SECULAR: Pressupostos}

\section{Crítica à Ética essencial e a falência do Projeto lluminista}

Qual é a essência da Ética ou da Filosofia Moral? Em que sentido pode ela ser questionada? O esclarecimento destas questões é de primordial importância para a compreensão da dimensão da crítica à ética essencial efetuada por Engelhardt. A essência da ética, pode-se dizer, está em estabelecer, a partir da determinação dos valores, os juízos morais, as normas ou regras decorrentes e em conceber uma explicação _ a justificação _ dos mesmos. São formulados necessariamente princípios e normas como os elementos válidos para uma teoria ético-moral da ação ou da conduta humanas, e tais princípios e normas constituem, então, a expressão de uma certa moralidade. Do ponto de vista clássico, e de um modo geral, a estrutura de um sistema ético poderia ser esquematizada assim:

VALORES $=$ compõem as categorias do Bem.

PRINCÍPIOS = fornecem as grandes orientações; delimitam atitudes REGRAS = organizam a decisão e determinam a conduta. 


\section{1. ÉTICA ESSENCIAL E MORAL CANÔNICA}

No pensamento de Engelhardt, a essência da ética não significa o mesmo que ética essencial. Esta idéia de ética essencial só adquire significado se for inserida no contexto da discussão do autor: 1) o horizonte que ele tem em mente é o da bioética, portanto a ética considerada é aquela que fundamenta questões relativas à vida :

2) se o universo é o da bioética, as questões que surgem são, por natureza, questões de tomadas de decisão envolvendo situações nas quais é preciso lidar com valores relativos à vida;

3) as controvérsias morais são inevitáveis e tornam-se o grande problema a ser resolvido, pois se há uma decisão a ser efetuada, há que se ter alguma orientação ética para basear a decisão.

Para Engelhardt, a idéia da ética essencial diz respeito à eleição de uma ética predominante: qual seria o melhor paradigma que poderia fundamentar o melhor julgamento? Uma ética baseada na razão (o projeto iluminista), nas emoções, ou na intuição? Mesmo se conseguíssemos escolher, ainda assim estaríamos diante de uma única perspectiva. Esta é a raiz da crítica de Engelhardt: seria impossivel, em bioética, admitir uma ética que fosse essencial em relação a todos os sistemas éticos e pudesse sanar as controvérsias morais. 
Para ele, aspirar a uma ética essencial é pretender "um ponto de vista que pressupōe que o mundo dos fatos, e muitas vezes o dos valores, tenha um padrão singular de coerência racional" (ENGELHARDT 1998, p.57). Para o autor esse ponto de vista é chamado de "pressuposição monoteísta", que significa a existência de "um único ponto de vista em termos do qual pode ser dada uma explicação concreta do conhecimento e da ética" (ENGELHARDT 1998, p.57).

Engelhardt considera que nem a filosofia e nenhuma ideologia podem aspirar à pretensão de revelar um "ponto de vista canônico" da realidade; em contraposição, é preciso assumir uma "pressuposição politeísta secular" em questōes de moralidade. significando que existem várias perspectivas morais igualmente defensáveis, mas bastante diferentes, responsáveis pela diversidade moral secular. A idéia de secularismo (que desenvolveremos adiante) refere-se, não a uma postura laica contraposta a posturas religiosas, mas ao reconhecimento de que existem várias e diferentes posições_ religiosas ou de outra natureza_ todas válidas do ponto de vista moral.

As controvérsias morais surgem na tentativa de estabelecer uma "moral canônica" (ENGELHARDT 1998, p.14,15,64) e justificar sua essência; a questāo é: como escolher racionalmente esta ética essencial e estabelecer um padrão mínimo comum em suas 
premissas? A preocupação de Engelhardł com a objetividade da moral pode ser percebida, a seguir:

Existe uma tensão fundamental entre alcançar o bem das pessoas e respeitá-las como agentes morais responsáveis e livres. Existem desentendimentos fundamentais em relaçāo a quem deveria definir - bem das pessoas, como e com respeito a quais padrōes. As questões de bioética são consideradas importantes, embora continuem causando divisōes. (...) No entanto, ainda permanecemos em profundo desacordo a respeito do que podemos fazer ou nāo fazer (ENGELHARDT 1998, p.34).

Engelhardt aponta outras dificuldades além da objetividade, entre elas o problema da justificação de uma moral particular. Teria que se determinar, por exemplo, quais seriam as regras da ação tidas como certas ou, como estabelecer qualquer procedimento como moralmente obrigatório; ou ainda, mais especificamente: como se pode mostrar que a moralidade em geral e a bioética em particular são mais do que questões de gosto?

A principal dificuldade é, então, determinar qual razão deveria orientar a escolha de uma ética que forneceria os 'cânones'l para a decisão, eliminando desse modo, as controvérsias morais. Necessita-se de um padrão que no caso da ética, e, portanto da bioética, na perspectiva de ENGELHARDT (1998), só podem ser encontrados nas seguintes circunstâncias:

\footnotetext{
'O uso desta palavra 'cânone' ou 'cânon' pelo autor é bastante reveladora e dá o sentido forte daquilo que ele quer explicar; a palavra 'cànone'. Em sua significação lingüistica, quer dizer regra geral de onde se inferem regras especiais; padrão, modelo, norma, regra; preceito de direito eclesiástico.
} 
1)"na própria essência das reivindicações éticas, em intuições, naquilo que parece declarar-se como certo ou errado, de maneira evidente, ou no mínimo:

2)em um estudo de casos exemplares,

3) nas conseqüências das escolhas morais,

4) em uma idéia de escolha sem preconceito, no ideal de um observador imparcial ou grupo de contratantes sem preconceitos,

5) na escolha moral racional ou no próprio discurso,

6) em uma explicação de jogo teórico (ou dilema de prisioneiro) dos problemas da interação social,

7) no caráter da realidade ou natureza,

8)em um apelo a princípios de nível intermediário, ou

9)em algum ponto de referência moral que pode canonicamente dirigir a escolha moral" (p.64).

Ao examinarmos essas opções veremos que em cada uma dessas abordagens existem problemas impossiveis de serem suplantados, pelo menos por três razões: a) um apelo a qualquer essência moral particular (portanto a uma ética essencial) traz à tona a questão dos padrões pelos quais a essência é selecionada; b) um apelo a uma estrutura formal não proporciona essência moral e, portanto nenhuma orientação moral essencial; c) um apelo a uma realidade externa demonstrará o que é, não o que deveria ser ou $\circ$ que deveria ser julgado. 
Além disto, para ele, as explicações éticas baseadas no intuicionismo, as casuísticas, as consenqüencialistas, as de lei natural e as com base em princípios de nível intermediário sofrem de problemas semelhantes aos citados acima, no que diz respeito a serem eleitas como justificações válidas para a questão. O motivo é que cada uma delas pressupõe exatamente aquilo que procura justificar: uma essência moral particular, ou seja, elas falham em pressupor o que pretendem estabelecer: a orientação moral canônica.

As controvérsias morais essenciais nāo podem ser resolvidas por meio de sólido argumento moral na ausência de premissas morais básicas comuns, regras de evidência e inferência, e visão de quem tem a autoridade moral (ENGELHARDT 1998, p.65).

Para Engelhardt, todas as escolhas pressupõem orientação moral particular. A essência moral é obtida somente a custo da particularidade, quer dizer: para ter essenncia moral é preciso endossar premissas ou regras morais particulares de evidência moral como ponto de partida, endossando, desse modo, uma dentre as moralidades disponiveis. Por outro lado, pondera o autor, para que uma moralidade tenha essência precisa ser particular mas com a particularidade, que essência moral deveria ser aceita (imposta?) e sob que bases? Ao se tentar responder estas perguntas acaba-se caindo em uma regressão infinita, girando em círculos e, diante 
dessas dificuldades nenhuma visão ou bioética moral particular pode ser considerada melhor do que qualquer outra.

Vejamos um exemplo comentado pelo autor sobre o aborto. Tema candente em bioética, objeto de discussões contundentes e acaloradas, justamente pelas posições morais envolvidas, de acordo com cada perspectiva moral. $O$ exemplo diz respeito a uma situação envolvendo um devoto batista americano _ que é contra a realização de abortos não-terapêuticos _ e o diretor ateu de uma clínica de abortos, que não vê maldade moral importante no aborto. O batista provavelmente considerará as pessoas que procuram pelo aborto para evitar um filho não-desejado como exemplos paradigmáticos de pessoas portadoras de valores deformados. Por outro lado, o diretor da clínica pode ver estas escolhas como exemplos paradigmáticos da perfeita liberdade das mulheres em exercer o controle sobre seu próprio corpo.

Segundo o argumento de Engelhardt, sobre a impossibilidade de justificação de uma ética essencial para decisão em bioética, ambos, os discutidores, vivem em mundos diferentes, com diferentes moralidades tidas como certas, e portanto não estarão compartilhando premissas morais comuns ou regras idênticas de evidência moral. Como eleger uma moral essencial?

Não é possível conceber uma ética da vida, uma bioética, que se debruça na reflexão e no julgamento de situações diversas cujas 
origens valorativas nos remetem a várias princípios e hábitos. Nem é possivel, em nome da diversidade, fundar (no sentido de gerar bases suficientes) uma ética que congregue todos os valores e princípios. Tal projeto, que o autor chama de projeto iluminista, teria a mesma natureza do projeto racionalista da época das Luzes (séculos XVII e XVIII) é fadado ao total fracasso. Portanto, à bioética não é possivel assentar-se sob uma ética essencial, como a essência da bioética, que forneça uma base para interpretar as questões relacionadas à vida, ou que envolvem a vida em seu sentido amplo. Mas a primeira pergunta é: como julgar o certo ou o errado? (Afinal a ética é como se fosse um pêndulo oscilando e dando o diapasão do certo ou errado). Como julgar eticamente, corretamente as questões-limite ou dilemáticas da bioética?

\subsection{FALÊNCIA DO PROJETO ILUMINISTA}

Também denominado de Esclarecimento ou Ilustração, o Iluminismo foi um movimento filosófico, literário, político e artístico que se desenvolveu na França, Alemanha e Inglaterra no século XVII e sobretudo no XVIII_ chamado 'Século das Luzes', em pleno período moderno. Mesmo com algumas diferenças, de acordo com a preponderância da fundamentação adotada e o tipo de movimento (Filosofia, Artes, Política), no geral, os partidários das 'luzes' 
se dedicaram a combater a ignorância e a superstição, caraterizando-se pela defesa da ciência, da racionalidade crítica contra a fé e o dogma religioso.

No que diz respeito ao significado ético-moral, para ENGELHARDT (1998) a modernidade é caracterizada pelo projeło de garantir, através da razão, "a substância da moralidade judaicocristã, juntamente com uma narrativa da autoridade moral não pela fé, mas por um sólido argumento racional. É a tentativa de preservar o centro da visão moral judaico-cristã sem a necessidade de confessar o Deus judaico-cristão. A tentativa de garantir esse centro da narrativa judaico-cristã de autoridade moral e de moralidade (embora agora ocorra em termos seculares), será freqüentemente mencionada como o 'moderno projeto filosófico' ou o 'moderno projeto filosófico moral' ou simplesmente o 'projeto filosófico moral" (p.24 e 29), na esperança de uma orientação moral, metafísica e ontológica. O projeto filosófico moral moderno antecede e permeia - lluminismo e as aspirações progressistas dos séculos XIX e XX, subsidiando o discurso moral secular. A expressão 'projeto iluminista' é usada para identificar a tarefa de estabelecer uma moral canônica, essencial em termos justificáveis para todas as pessoas. A pósmodernidade mostrou a decadência e a falência desse projeto, pela perda da fé, pela fragmentação da cultura ocidental e pela limitação da fundamentação racional. 
Por pós-modernidade ENGELHARDT (1998) considera o período fortemente marcado pela variedade de mudanças sociais, industriais e tecnológicas que se destacaram principalmente após a II Guerra Mundial, e também pelo rápido crescimento de uma nova tecnologia do conhecimento, que propiciou a coleta de dados, simulação e análise de sistemas. Nesse período "pós-industrial", costuma-se dizer que o computador é, para a produção do conhecimento, $\bigcirc$ que a locomotiva foi para a produção de materiais (p.27).

O principal significado de pós-modernidade para o nosso estudo é que este período identifica as condições sociológicas e epistemológicas da perda de uma narrativa universal como sendo a base de uma visão da condição e experiência humana, com capacidade para apontar e justificar a essência dessa narrativa. Esse sentido de ausência no qual se inclui a significação do discurso da moral secular é de extrema importância na discussão da ética secular, dado que as questões de bioética contemporânea surgem diante de um contexto de fragmentação da perspectiva moral e ao mesmo tempo de pluralidade de visões morais, de ceticismo, perda de fé e de um quadro de desafio permanente da política de assistência à saúde.

O projeto moderno filosófico moral tinha como proposta garantir, somente pela Razão, o centro de uma visão moral e de uma 
decorrente autoridade sem o compromisso de uma revelação particular, que o medievo prometia proporcionar, através da crença em sua fé particular. Muitos admitiam ser possivel banir os resquícios irracionais da fé religiosa e levar a vida sob a luz da moralidade essencial que o racionalismo pode proporcionar. $O$ fracasso do projeto filosófico moderno, ou do projeto iluminista, se constitui na impossibilidade da hegemonia de uma moral canônica essencial. A racionalidade secular moderna se transformou em muitas racionalidades. Em nossa era pós-moderna fragmentada, constatamos que não fomos capazes de descobrir uma moralidade secular essencial que abrangesse as diversas comunidades de crenças religiosas e ideológicas, oferecendo uma essência moral para todos.

A bioética em nossa época contemporânea tem como tarefa voltar-se para a viabilidade e busca de fundamentos ético-morais para uma sociedade pluralista, secular, conformada em comunidades de diversas seitas, sentimentos e crenças morais. ENGELHARDT (1998) observa que muitos dos que trabalham com ética aplicada ou bioética parecem ignorar as dificuldades desta tarefa, demonstrando persistência em não reconhecer a fragilidade e ineficácia do projeto moral moderno, como se fosse óbvio qual ética deveria ser escolhida e aplicada. Os partidários dessa prática seguem uma ortodoxia em sua postura: agem como se uma bioética 
essencial pudesse ser o norte da decisão moral das questões, dos problemas e das situações surgidas. Essa resposta resulta em uma imposição de visão moral particular ou ideologia na qual os consultores e conselheiros acabam funcionando como se fossem sacerdotes, rabinos ou ministros, como se estivessem em um contexto religioso, mas sem reconhecer em absoluto sua postura sectária ou seu fundamentalismo. Temos como exemplo a posição diante de questões como a relação médico-paciente, o consentimento livre e informado, a alocação de recursos na saúde: cada um tem uma perspectiva diferente de como solucionar tais problemas. Falam com conhecimento de causa e com a conviç̧ão da razão, sem reconhecer os compromissos morais particulares que, de fato, orientam suas escolhas. Discutem sobre justiça e imparcialidade, oferecendo fundamentos teóricos acerca da essência, dos princípios e dos valores que permeiam a ação moral, propondo ao final, uma postura canônica, que simplesmente não existe na realidade da sociedade ocidental constituída em nossa época (p.35).

\section{Humanismo, Secularismo, Pluralismo}

Para Engelhardt, refletir sobre bioética na época contemporânea significa reconhecer seu caráter crítico diante de questões relacionadas à assistência à saúde, como os poderes da 
medicina, as tecnologias médicas, as ciências biomédicas à luz da moralidade que emergiu a partir dos valores que se constituíram com as condições históricas dos paradigmas falimentares do medievo (caracterizado pela influência dominante da religião) e da modernidade (definido pela defesa do universalismo da razão). Grande desafio que o autor tenta enfrentar propondo alguns pressupostos para a reflexão da questão; inicia analisando a concepção de humanismo que desembocará na idéia de secularidade, pautada por uma constatação do pluralismo, enquanto elementos imprescindiveis para o entendimento da moralidade em nossa época, subjacentes à possibilidade de uma bioética.

Contemporaneamente vive-se uma época de fracasso da religião e da razão em estabelecer uma explicação canônica para questões relativas à moralidade ou à justiça, mesmo que tradicionalmente sempre estivessem à frente ditando procedimentos e normas de ação para os problemas morais. Por outro lado observase, paradoxalmente, uma proliferação de seitas religiosas, e, diante disso, onde se situa o tal fracasso? Ele se constitui no fato de que a religião, seja ela qual for, não é mais o diapasão para a moralidade da época contemporânea. Nem mais a razão originada como essência do novo paradigma na época moderna, quebrando a hegemonia da religião medieval _ consegue permanecer como 
fundamento da moralidade e da teoria política, principalmente a partir dos questionamentos e dos desenvolvimentos filosóficos e científicos do século XIX.

O mundo contemporâneo caracteriza-se por uma fragmentação e uma polarização de alguns e por uma apatia por parte de outros, quanto a uma clareza em relação à ação moral, ética e social. Isso se reflete claramente em confrontos ou discordâncias, quando há decisōes a serem tomadas como certas ou erradas. Na prática da saúde os conflitos vem à tona quando há a necessidade de ajuizar ou tomar decisões éticas envolvendo, por exemplo, novas descobertas em genética ou medicina relacionadas a temas (às vezes não tão novos, mas controversos) como definição de morte, eutanásia, início da vida, clonagem, transgênicos, entre outros desenvolvimentos.

Resgatar o significado de humanismo pode ser uma forma de recolocar o homem como o centro da ação moral, pois parece ter sido relegado o sentido humano implícito na essência da ética. Estabelecer os sentidos de secularismo e de pluralismo são necessários para que o autor contextualize o humanismo secular e sua perspectiva da bioética, no âmbito da assistência à saúde. 


\subsection{HUMANISMO}

Martin Heidegger (1889-1976) recoloca a mesma questão que na antiguidade já instigava os gregos: "(...) em que consiste a humanidade do homem?" "Como tornar a dar sentido à palavra 'Humanismo"?2 (HEIDEGGER 1979, p.152 e p.150). Ao relembrar a preocupação heideggeriano, ENGELHARDT (1991) considera que essa compreensão se traduz em "um quebra-cabeças metafísico, moral e estético. Sua questão é central para compreender o próprio foco da medicina e o próprio caráter da bioética porque ambas dizem respeito à natureza do bem-estar humano" (p.43).

Há um conjunto de palavras com significados semelhantes, originados do termo latino Homo, os quais refletem a ambigüidade em torno dessa idéia: humanidades, humano, humanamente, humanitário, humanismo humanidade, etc. Referindo-se aos cursos de medicina. Engelhardt comenta que cada um desses sentidos pode, de algum modo, ser relacionado a uma interpretação de medicina humanística, a qual pode ser entendida uma formação que congregue, além dos conteúdos técnicos especializados, conteúdos de ciências humanas, podendo, desse modo, também contribuir para um projeto estrutural de justificação da bioética.

\footnotetext{
2 . Comment redonner un sens au mot "Humanisme"? Ao traduzir a obra de Heidegger "Sobre o 'Humanismo", (escrita em 1949, originada de correspondência com Jean Beaufret), o tradutor $E$. Stein conserva no corpo do texto em português a frase em francês, traduzindoa em nota de rodapé (p.150).
} 
Buscar as origens na antigüidade grega e seus desdobramentos através dos séculos ainda é uma tentativa para compreender ideais exemplares que foram erigidos em torno da capacidade humana como modelo para a cultura. Portanto, é impossivel explicar solidamente o humanismo secular ou as visões da bioética contemporânea sem examinar esse conjunto de idéias. imagens e colagens em torno do termo 'humanismo'.

Especificamente, uma das conotações da palavra 'humanismo' diz respeito ao papel da filosofia em propor uma ética ou moral com base na condição humana e nos ideais comuns ou compartilhados pelos homens. $E$ isso só pode ser plenamente justificado a partir do entendimento da variedade de significados e de como eles emergem. Entre os estudiosos da questão, há um consenso quanto à ambigüidade em torno do Humanismo, mas também há o reconhecimento de que, mesmo havendo uma trama de conceitos enredados e até mesmo uma retórica e uma vaguidade, é uma noção extremamente frutífera para captar o sentido da civilização e da cultura ocidentais até nossos dias.

Em um sentido amplo, mas de extrema significação, podemos iniciar interpretando o humanismo a partir de uma frase do filósofo Protágoras (485-411 a.C.): "O Homem é a medida de todas as coisas; 
das que são, que elas são, e das que não são, que elas não são"3. CHAUí (1994, p.129 e 130)) faz uma interessante interpretação do adágio "o homem é a medida de todas as coisas", esclarecendo que este é formulado por dois motivos, em relação às preocupações que teria tido Protágoras:

a) a medicina existe porque o homem passa da doença à saúde e vice versa; embora possa constituir um saber próprio, suas características sempre serão referidas ao indivíduo porque a cura é individual, critério (medida) da ação do médico;

b) os homens criaram inúmeras técnicas, mas nem sempre conseguem harmonizar os interesses e a adequação. Na busca por uma compatibilização e eliminação de conflitos é preciso encontrar um critério (medida). Essa harmonização só pode ser encontrada através da política, pois as leis têm os homens como medida. É através da justiça vigente entre os cidadãos_a qual existe para preservar a ordem social_e através das leis que se preservam os costumes que deram origem à ordem existente em uma cidade (pólis). Cada cidade é a medida de sua própria justiça.

\footnotetext{
3 Segundo HUISMAN (2000, p.249) e CHAUí (1994, p. 129) a obra de Protágoras de Abdera (considerado o primeiro dos sofistas), nos chegou fragmentada, näo sendo possivel saber exatamente as obras que escreveu; seriam suas obras Sobre a verdade e sobre o ser, Sobre os deuses. Um dos mais célebres diálogos de Platão (427-347a.C.) chama-se Protágoras (entre outros personagens, o próprio Protágoras, Sócrates e Hipócrates). No diálogo o Sofista Platão faz, especialmente, uma referência critica ao relativismo de Protágoras, quanto ao problema do ser.
} 
Para abarcar o sentido de Humanismo, Engelhardt desenvolve nove blocos de idéias a partir da história do humanismo, incluindo termos cognatos; os quais procuraremos sintetizar abaixo.

1. Humanitas: tem o significado de educação ou cultura, aproximando-se, do termo grego paideia; entendido também como raça humana, maneiras refinadas, gosto cultivado pelo modo de viver, dignidade humana, nobreza, gentileza, cortesia, erudição, urbanidade, refinamento _ conotações associadas a uma noção de bem-estar do homem.

2. Humano: entendido como filantrópico ou humanitário. Entre os romanos, humanitas indicava não somente educação refinada mas também clementia, uma certa gentileza associada à filantropia. Note-se que a filantropia expressava uma das facetas do ideal médico hipocrático. Ser humano tem o sentido de ser humanitário, correspondendo a uma disposição para agir na suavização do sofrimento e suprimento das necessidades, incluindo os humanos e os animais.

3. Humanidade: como nobreza de princípios; pode ser entendido de duas formas. A primeira como um coletivo usado para identificar genericamente os humanos; a segunda como uma expressão louvável, elogiável e valorativa de atitudes de nobreza, de bons sentimentos e de educação. Sugere, na prática médica, que os 
profissionais tenham, não somente características biológicas humanas, mas que realizem determinados ideais morais humanos.

4. O Humanista: como o professor, o especialista ou o estudante. Criado no final do século XIX para distinguir um professor da área de ciências humanas, mas posteriormente o termo se estendeu aos estudantes. Segundo Engelhardt, as escolas médicas americanas, mesmo hoje, defendem (embora a realidade não seja exatamente essa) que o aluno deve se familiarizar com os principais ideais da herança cultural ocidental para que tenha melhores condições para entender seus pacientes e proporcionar uma assistência mais humanizada.

5. Humanidades: a partir da Renascença, usado para designar as artes liberais, as belas artes e a literatura. É definida também como o estudo de Ciências Humanas e como a discussão e a produção de conhecimento dessa área que auxiliam a entender melhor as possibilidades da condição humana. Fora desse contexto, se faz referência à bioética como um dos desdobramentos "das humanidades (ou da área de humanas) na medicina". Na Renascença, os studia humanitatis incluíam somente o estudo básico dos idiomas grego e latino, gramática, poesia, filosofia moral, ética.

6. Humanismo: entendido como erudição. No início da Renascença, o humanismo referia-se ao interesse pelos originais gregos e latinos. A redescoberta do platonismo torna-se o marco desse período. 0 
fascínio do humanismo pela Antigüidade e, portanto, pelas coisas pagãs, acaba sendo relacionado a sentimentos anticristãos, pelo verdadeiro culto pela literatura grega em detrimento das escrituras judaico-cristãs. A 'literatura humana' sugere um contraste com a 'literatura divina', apesar dos interesses associados ao humanismo virem apoiar um domínio da erudição hebréia e bíblica. Muitos estudiosos como Rüdiger ${ }^{4}$ consideram que desde a Renascença, outros períodos de renascimento aconteceram na Alemanha, compreendidos enquanto períodos de interesse pela literatura da Antigüidade; são eles: o novo humanismo, aproximadamente entre 1760-1830 e o terceiro humanismo, no final do século XIX, mais ou menos vinte anos depois do humanismo histórico-cultural.

7. Humanismo: como equilibrio, balanceamento. A idéia de humanitas e paideia dizem respeito a uma postura peculiar de equilibrio, mais relacionada ao cultivo, à fruição do que à produção. Associada a uma relação entre as artes liberais e lazer que, no contexto da época, apontariam para a uma vida que incluiria o ócio e a dignidade como valores e para uma certa sabedoria em 'levar a vida'. Neste sentido humanismo significa, com base na intuição, gerar um estilo para a ação, relegando a virtude intelectual para um plano menor.

\footnotetext{
${ }^{4}$.Horst Rüdger, citado por ENGELHARDT (1991, p. 47).
} 
8. Humanismo: como um conjunto de valores. Constituem teorias e propostas filosóficas que procuram expressar os próprios ideais e visōes acerca da natureza e conduta humanas, de acordo com o pensamento de seus autores. É sob essa perspectiva que freqüentemente são fornecidas respostas particulares para as controvérsias em bioética. Além disso, humanismo também tem sido interpretado como um conjunto de valores que servem de suporte na compreensão de empreendimentos como a ciência, a medicina e a tecnologia. Estas concepçōes de vida moral e de bem-estar delineiam-se, mesmo com uma certa distância, na confiança das capacidades e habilidades dos indivíduos assinaladas na Renascença.

9.Humanismo: como base filosófica tanto para um entendimento moral comum quanto para uma negociação entre os indivíduos que abraçam valores e princípios diversos _ denominados por Engelhardt como estranhos morais. Trata-se, no entanto, de considerar o humanismo como uma forma de buscar o que existe de comum entre valores que possam servir de base para uma moralidade geral, no intuito de solucionar controvérsias em bioética, incluindo as discordâncias na política de assistência à saúde. Para Engelhardt

Somente se este último sentido de humanismo puder ser justificado os indivíduos que se vêem como estranhos morais encontrarão o que compartilhar para estruturar uma politica de assistência à saúde, reconhecida como tendo autoridade moral e intelectual (ENGELHARDT 1991, p.48). 
A partir dessas nove possibilidades em torno das interprełaçōes de Humanismo (anteriormente numeradas de 1 a 9 nessa seção), Engelhardt faz uma retomada e um reagrupamento relacionado-as, em um esforço mais explicito de reflexão sobre questões éticas e filosóficas e o surgimento da bioética. Três observações são feitas nessa direçāo, abaixo designadas por ítens A), B) e C):

A) O humanismo pode ser expresso através do caráter e da qualidade da assistência em saúde. Aspiração possivel, se admitida no conjunto dos objetivos da educação médica e da proposta da bioética: dar condições de assistência à saúde de modo a atender e considerar seriamente as necessidades, os interesses e os desejos dos pacientes. Interesses, necessidades e desejos humanos são temas que percorrem tanto a história do humanismo quanto da medicina_ envolvem um olhar beneficente e de compromisso em relação àqueles que precisam dos serviços de saúde. Nessa direção $(2,3)$ acrescenta-se um outro sentido (7) que se dirige ao senso médico de proporção: humanismo como uma capacidade de balanceamento para decidir a respeito da alta-łecnologia na área médica, e também na facilidade do médico em trazer as implicações dessa altatecnologia de tratamento e diagnóstico para uma compreensão humana. 
B) Humanismo como um corpo de conhecimento e aprendizado: uma comunidade de professores, pesquisadores, estudantes, enfim, uma espécie de refinamento intelectual voltado para um contexto intelectual ético, estético e de ciências humanas que possa proporcionar as bases de uma formação que Engelhardt chama de medicina humana. Estas seriam metas de uma educação em saúde, ampliando não só para a medicina, como também para a enfermagem e para outras formaçōes da área da saúde. $(1,4,5)$. Os novos conhecimentos em saúde novas drogas, novos procedimentos, tecnologias genéticas inovadoras, novas terapêuticas e técnicas, novas maneiras de conceber algumas questões em saúde _ desenvolvidos com extrema rapidez principalmente na medicina, dificultam a absorção e a atualização dos profissionais causando uma conseqüente subespecialização que se reflete na hospitalização e até mesmo na dinâmica dos provedores de saúde. Estes, mesmo com consultoria altamente especializada, participam dessa obsolescência. Nesse sentido, as humanidades (como história da medicina e bioétical poderiam contribuir ao oferecer uma formação adicional que resgatasse as visões de mundo, idéias e imagens constitutivas de nossa cultura clássica. Um entendimento refinado da condição humana, tais como a maneira como os individuos nascem, se desenvolvem, são tratados, crescem, 
envelhecem, morrem _ uma rede de questões investigadas tradicionalmente nas ciências humanas, poderiam resultar em uma prática de saúde integral e efetiva. Certos textos antigos, por exemplo, apresentam um grande e peculiar interesse na atualidade, veja-se o legado de Hipócratess, a Ética a Nicômanco (ARISTÓTELES 1979, p.45-236) e os Diálogos (PLATÃO $s / d)^{6}$.

C) Humanismo como um corpo teórico de filosofia e moral a partir do qual a bioética possa ser justificada (8, 9), e a possibilidade, portanto, da compreensão de uma moralidade secular e do desenvolvimento

de uma bioética secular embora diferindo em termos de sua possibilidade de generalização. A moralidade secular não somente está embutida, mas essencialmente condicionada por uma história e por um conjunto particular de idéias; freqüentemente se expressa em organizações formais (91. A bioética secular traz à tona a questão se a moralidade para estranhos morais, com verdadeira generalidade, pode ser intelectualmente justificada em termos da natureza do homem e da condição humana.

\footnotetext{
5 . O legado de Hipócrates, (médico eminente da Grécia antiga), pode ser encontrado em qualquer obra de História da medicina; nossa referência é CASTIGLIONI (1947, p.174-188).

6. Platão de Atenas (427a.C.-348 a.C.), Aristóteles de Estagira (384 a.C.-355 a.C.).
} 
Mesmo assim, tanto a bioética secular quanto a moralidade para estranhos morais compartilham a meta de descobrir e mostrar um conjunto de constrangimentos morais fundamentais na direção de uma hierarquia de justificação ou uma explicação de anseios morais. Em qualquer um dos casos, as tentativas exemplares em articular uma base comum para a cooperação entre estranhos morais são beneficiadas. Podemos lembrar, a título de ilustração, como exemplo, a proposta de Kant na obra Projeto de Paz Perpétua7, sobre uma coligação de nações.

No que diz respeito aos amigos morais, as associações particulares de humanistas e suas organizações sociais constituírem uma particularidade. Organizam-se sempre acima e contra os outros. Entretanto, se existe uma base comum para a cooperação entre estranhos, isso supre os fundamentos de uma comunidade moral e os estranhos morais poderão se entender encontrando uma base de justificação moral para a cooperação, simplesmente porque são humanos ou pessoas.

Humanismo como interesse humano (A) destaca a ação comunitária; pressupõe um claro compromisso na direçāo do bem e sua obtenção através da tecnologia.

\footnotetext{
?. Escrito em 1795, seis anos depois da Revolução Francesa, Kant escreve a favor da criaçāo de uma liga de naçōes destinada a estabelecer as condições para a paz mundial.
} 
Humanismo como um corpo acadêmico altamente especializado e de aprendizado (B) prioriza o estudo dos clássicos pautado na erudição e no pensamento, visando a uma cuidadosa reflexão sobre o que seria melhor para o ser humano. Aliados a desenvolvimentos científicos bem direcionados, como a tecnologia, juntos poderiam auxiliar no alivio do sofrimento, objetivando o bemestar do homem.

Humanismo como um corpo de teorias filosóficas e morais (C) acentua a importância do desenvolvimento de explicações filosóficas, que não sejam simples propostas axiológicas. Destaca a necessidade do entendimento que une os estranhos morais entre si no intuito de vislumbrar uma possibilidade de empenho conjunto nas decisões relativas à saúde.

As três interpretaçōes porém, versam sobre diferentes visões do bem-estar humano e sobre como atingi-las. Mas as diferenças entre elas são uma questão de ponto de vista, valores, princípio filosófico ou mesmo de postura quanto à melhor formação em saúde; por outro lado, cada uma delas torna plausivel uma compreensão diferenciada de como a assistência na saúde pode estar a serviço do homem.

Cada uma dessas interpretações do humanismo traz em si uma força de secularização. 


\subsection{SECULARISMO}

Secular, em sentido amplo, neste estudo, designa os assuntos temporais ou profanos em relação aos religiosos; refere-se também à esfera do humano, o mundo. Historicamente está relacionado a reações de discordância ou crítica ao poder constituído da Igreja Católica no período medieval.

Tomando as metáforas 'cidade de Deus' e 'cidade dos homens', de Santo Agostinho (354-430), filósofo e bispo de Hipona, ENGELHARDT (1991) situa a esfera de significância do conceito de secular (p.21). A cidade de Deus (SANTO AGOSTINHO 1990), escrito em 413, época em que o Império Romano, enfraquecido e falido, enfrentava muitos problemas como a pilhagem e saqueio na cidade de Roma, para Agostinho a 'cidade de Deus' era a comunidade das almas dedicadas a Deus que, em última instância seriam salvas; a 'cidade dos homens', constituía-se daqueles dedicados a esse mundo condenado e decadente. É oportuno notar que, diferente de ARISTÓTELES (s/d) _ que considerava o "homem um animal político" _ para Agostinho a natureza humana era social, embora admitisse como necessária a vida política para a sociedade. Os homens de ambas as 'cidades' viviam juntos, em uma estrutura secular aberta que beneficiava a ambos: desse modo a 'cidade secular' era um espaço neutro no qual santos e pecadores se encontravam. 
Secular diz respeito ao mundo em geral, enquanto realidade permanente externa, no qual homens e mulheres de todas as tradições podiam compartilhar. ENGELHARDT (1991, p.23-29) destaca sete sentidos de 'secular', (que resumiremos abaixo), aliando termos como secularização e secularismo; cada um, em seu sentido próprio, tem uma conotação comum de algo mundano, separado do espiritual ou eclesiástico.

1.Secular como uma estrutura moralmente neutra na qual crentes e não-crentes podem colaborar entre si. "Ser secular é estar no mundo, é fazer parte do tecido carnal da existência do dia-a-dia" (ENGELHARDT 1991, p.23). Secular delimita as estruturas mundanas compartilhadas por todos em oposição às estruturas espirituais compartilhadas somente pelos que estão sob a graça divina. Historicamente, esse uso do termo secular remonta ao século VI, à época do imperador Constantino (527-565), na expressão latina saeculo renuntiare se atribuiu o significado de 'renunciar ao mundo'.

Esse primeiro sentido é o mais importante para a compreensão da extensão do termo "bioética secular": como uma bioética acessivel a individuos, independentemente de sua moral particular, ideologia e tradição de fé.

2. Secular, opondo o espiritual ao secular, mas em um contexto específico, que é o das leis canônicas da Igreja Católica Romana. Refere-se a clérigos que não fazem votos e, portanto, não estão sob 
as regras de uma ordem religiosa (secularis); vivem fora dos conventos imersos nas situações e problemas de sua época, de sua geração, apesar de terem um forte sentimento de dedicação à religião. Opõem-se aos clérigos de convento, que fazem votos e vivem conforme uma ordem religiosa e suas normas (regularis).

3. Secularização: como um termo para identificar um processo na lei canônica da Igreja Católica, quando um clérigo se converte em um clérigo secular ou uma propriedade religiosa é dada a clérigos seculares. A secularização abranda os votos e as obrigações da ordem religiosa; oficializa a situação, por exemplo de um bispo que se afasta da vida monástica de sua ordem. Não tem o mesmo significado de laicização que é o processo em que um clérigo católico se desobriga de seus deveres e fica reduzido a um leigo _ por exemplo, um padre dominicano secularizado permanece distante das regras da ordem, mas é ainda um padre, e um padre dominicano laicizado é dispensado das obrigações de um padre e então pode viver no mundo e até se casar.

4. Secularização: termo com um sentido político e mundano; usado para designar os vários passos de um processo legal que transformou a Europa cristã na Europa contemporânea pelo confisco de propriedades que pertenciam à Igreja Católica. Através dos tempos, houve uma acumulação de terras pela Igreja Católica medieval, que estava acima das leis e impostos dos vários países, mas depois da 
Reforma e da constituição da Igreja Anglicana, que criticaram acirradamente a riqueza das instituições católicas durante os séculos $\mathrm{XVI}$ e XVII, as terras começaram a passar do poder eclesiástico para o poder laico. Em 1646, tem-se o registro do termo secularização para a conversão das propriedades da Igreja em propriedades estatais ENGELHARDT (1991, p.24). Havia um interesse também da própria Igreja em desfazer-se das acusações de corrupção, luxúria e poder temporal. Ao render-se à secularização de propriedades, de alguma maneira ela se penintenciava diante de seus erros, abrindo mão de suas posses para beneficiar a sociedade, tentando demonstrar assim despojamento diante de coisas mundanas como propriedade e poder. A separação entre poder eclesiástico e poder secular é a distinção que está subjacente ao sentido de secular que Engelhardt defende em sua proposta, quando se refere ao humanismo secular e à bioética secular.

5. Secularidade: tem o sentido de limitar ou anular os poderes, imunidades e influência da Igreja Católica. Corresponde aos atos de confronto ao catolicismo ocorridos principalmente na França do século XVIII, na época da República. Houve uma hostilidade manifesta em relação à Igreja Católica; o clero estava sob ordens do poder estatal que exigia pagamentos de recompensa pelo confisco e pelo controle das propriedades. O florescimento do lluminismo com a proposta da racionalidade como forma de ver o mundo _ a Razão 
enquanto a luz que clareia o obscurantismo vigente do medievo de influência ortodoxa cristã _ é um dos sinais de reação contra o catolicismo (ENGELHARDT 1991, p.25). O governo procurava remover da vida dos franceses sua influência; um exemplo curioso é o estabelecimento do casamento como um ato civil, e com ele o questionamento e o incentivo do casamento dos clérigos, numa postura de claro desafio às ordens religiosas. Os conflitos com a Igreja e as autoridades civis eram instigados em larga escala e, em 1798, segundo ENGELHARDT (1991, p.26), a França apoiava a proclamação da República em Roma tendo como uma das conseqüências de afronta à soberania da Igreja a prisão do Papa Pio VI (1775-1799) e de seu sucessor Pio VII (1800-1823), ambos enviados à França lo primeiro vindo a falecer em 1799). Tais medidas contavam com a anuência de Napoleão Bonaparte, que impunha sua política e reformas de Estado, das quais o enfraquecimento da hegemonia da Igreja era um dos objetivos, implementando essa postura à Europa conquistada. Ressalte-se que as relações entre o secular e o espiritual foram totalmente estranguladas por Bonaparte. A secularização nesse sentido se tornou uma resposta forte à dominação política. moral e econômica da Igreja na proposta anticlerical de remover ou diminuir radicalmente a influência católica. Essa deliberação foi por muito tempo um programa de liberação do passado e de instauração da ldade Moderna para vários países como União 
Soviética e México. Esse sentido de secularidade também é entendido como laicização, e foi largamente discutido como medida de reorientação dos costumes no intuito de extirpar a influência da Igreja na formação cultural francesa, inclusive dando origem a programa laico de política educacional para as escolas públicas, especialmente no periodo de 1879 a 1886.

6. Secularização: visto como um movimento dirigido para o estabelecimento de estruturas neutras na sociedade. É constituido a partir dos movimentos sociais e políticos do século XIX, que objetivavam a liberação das estruturas sociais da influência da religião. Um dos principais questionamentos, acompanhando a tradição filosófica, era investigar a possibilidade de fundamentar a moralidade sem levar em conta um Deus ou a imortalidade da alma ${ }^{8}$. Geralmente essa e outras questōes semelhantes tinham em comum o seguinte: não se caraterizavam por terem um cunho teísta ou ateísta e se colocavam contra a postura de confronto e hostilidade, adotada 70 anos atrás. Esse tipo de pensamento se preocupava mais em unir os livre-pensadores e os interessados em refletir na direção do bem material dos cidadãos e da sociedade. Para Engelhardt, esse sentido se equivaleria à moralidade dos estranhos morais, ou pelo menos à moralidade dos que não concordavam com a existência incondicional de Deus e com o significado da religiāo.

${ }^{8}$. George Jacob Holyoake, citado por ENGELHARDT (1991, p.27). 
7. Secularidade: como um processo no qual o sentido da religião (ou de algo transcendente) em uma sociedade ou cultura é transformado em um sentido imanente e mundano. "Secularização é a liberação do homem da tutela religiosa e metafísica, voltando-se a atenção de outros mundos universos para o universo humano"9 Elementos de secularização perpassam a filosofia e a ciência da época moderna (principalmente no século XVII), propiciando um movimento europeu de reorientação das estruturas sociais e religiosas. Na filosofia, grandes pensadores manifestam estas características seculares em sua obras _ como Thomas Hobbes (1588-1790), Immanuel Kant (1724-1804) e Adam Smith (1723-1790)

pelo pouco interesse em questões teológicas e maior preocupação com questões mundanas e do homem. No século XIX, é preciso citar Karl Marx (1818-1883) e os marxistas que, na frase célebre, concebem a "religião como o ópio do povo", entendendo que esta seria uma falsa consciência oriunda da alienação do homem. A secularização, neste sentido passa a ser amplamente entendida como um processo que promove um enfraquecimento da influência da Igreja Católica. Embora seja dirigida ao catolicismo com mais ou menos 1200 anos de hegemonia, também as igrejas protestantes, de alguma maneira, sofrem esse processo e, em ambas a tônica é a mesma: nessa conjuntura muito mais contra o centralismo cultural, e não

\footnotetext{
${ }^{9}$. Harvey Cox, citado por ENGELHARDT (1991, p.32).
} 
tanto contra seu poder financeiro e político. A secularização vai sendo direcionada para a quebra do controle cultural no sentido da linguagem e da expressão, dos símbolos e de sua veiculação e da sua conseqüente significação no seio das sociedades. Há também um outro entendimento de secularidade como um fenômeno social que vem associado à industrialização, urbanização e conseqüentemente à mobilidade e ao anonimato.

ENGELHARDT (1991) delimita o sentido de 'secular', o qual agrega em sua proposta de humanismo secular e bioética secular:

Eu uso 'secular' (...) para identificar o que é aberto para todos, independentemente de uma moral particular ou tradição religiosa, mas não em explicita oposição à religião. Este sentido encarna uma política de assistência à saúde que não incorpora nenhuma hostilidade a visōes religiosas (p. 32).

Para ele, esse processo de secularização através dos tempos acabou moldando as instituições de assistência à saúde, dado que em sua maioria não são controladas por grupos religiosos. Desenvolveu-se, um discurso moral secular, de cunho analítico e crítico e bem articulado que se tornou a base das discussões na saúde e na medicina _ saúde, doença e assistência médica podem ser analisadas e pensadas sem a referência a valores ou objetivos religiosos. A bioética contemporânea, mesmo que alguns não reconheçam, é em grande escala, um produto de forças seculares. 
Mas algumas questões permanecem: como identificar e caracterizar uma estrutura secular neutra _uma instituição de saúde_ na qual crentes de várias religiões e não-crentes tenham acesso comum? Segundo Engelhardt, a questão é atribuir um conteúdo moral às políticas que governam as instituições de assistência à saúde; por exemplo: como alguém deve justificar as regras de conduta em um hospital secular em oposição a um religioso? Que espécie de padrões morais um hospital apoiaria se ele não tem uma tradição moral particular e recebe pacientes, médicos, enfermeiros de diversas tradições de fé? E em sentido contrário, se o hospital pertence a uma tradição religiosa específica? Ou de forma geral: como moldar uma política secular para oferecer assistência à saúde?

\subsection{PLURALISMO}

A concepção de pluralismo (ABBAGNANO 1999, p.765) diz respeito ao reconhecimento: da possibilidade de soluções diversas de um mesmo problema ou, de interpretações diversas da mesma realidade ou conceito ou de uma diversidade de fatores ou de desenvolvimentos e situações na mesma área de estudos. Pode-se dizer que o pluralismo designa a tese de que a diversidade, a heterogeneidade e a descontinuidade prevalecem_ seja em que 
área for, inclusive na ciência__ sobre a identidade, a homogeneidade e a continuidade.

Para (HELD 1992, p.839) o pluralismo moral constitui-se na visão de que valores, obrigações, virtudes, ideais ou princípios morais fundamentais são inerentemente diversos e inconciliáveis em um sistema estrutural de moralidade. Os valores, constata-se ao longo da História, podem ser incompatíveis em várias circunstâncias: entre as culturas (por exemplo entre a antiguidade grega e a romana), entre grupos da mesma cultura (entre católicos e budistas no Brasil), entre pessoas (indivíduos de caráter ou personalidade diferenciadas) e até mesmo no interior de uma mesma pessoa (por exemplo, alguém para si não aceita e nem pratica o aborto, mas admite que outro tenha a necessidade de fazê-lo). É preciso, porém, esclarecer que pluralismo não é identificável com o relativismo, dado que o primeiro rejeita a visão (aceita pelo segundo) de que valores sejam entidades meramente subjetivas, quer dizer, uma questão de gosto ou crença cultural. A característica fundamental pluralista, no que diz respeito à ética, é a diversidade dos valores morais.

O pluralismo moral, muitas vezes, é o suporte para que questões de dilema possam ser tratadas com maior realidade. Vejamos um exemplo: uma pessoa pode ser incapaz de satisfazer os dois seguintes princípios morais válidos: de dizer a verdade e de impedir um dano desnecessário (esta questão é aplicável a qualquer situação de 
rotina na área médica ou de enfermagem). Na visão da moralidade, esta pessoa tem um conflito real de obrigações e não pode furtar-se a ambos. Existe ainda uma outra visão de que os dilemas morais surgem entre pessoas, nas quais conflitos morais podem ser intratáveis. Pode-se dizer, então, que o pluralismo moral defende que as recomendações incompativeis podem ser moralmente vinculadas a partir de circunstâncias peculiares que dependerão da situação e das comunidades envolvidas. Importante ressaltar que a proposta moral pluralista é apenas um modelo teórico, não se constituindo, por si só, em uma posição anticlerical, antiteológica nem antireligiosa ou materialista.

Não há moralidade essencial sem um compromisso moral particular. Não existe bioética essencial fora de uma perspectiva moral particular. Além do mais, existem muitas e profundas interpretaçōes morais diferentes: a bioética está no plural (ENGELHARDT 1998, p.36). (O grifo é nosso).

Engelhardt não acredita na proposta de uma ética canônica, particular, ou seja, na proposta de uma ética predominante, hegemônica, detentora de valores específicos a serem adotados, nem em princípios que dêem a direção do agir e as normas de conduta para todos_ uma ética baseada na razão ou uma ética universalizante. Ou melhor, ele não considera que um sistema ético possa ser abrangente o suficiente para suprir os contornos culturais das comunidades ou dos povos. Para ele a idéia de pluralismo parte do pressuposto (ou da constatação) de que há uma variedade de 
visões morais, obrigaçōes, direitos e valores, muito diferentes entre si. Existem homens, mulheres, judeus, católicos, protestantes, muçulmanos, hindus, budistas, marxistas, liberais, capitalistas, socialistas, etc. e esta situação é facilmente verificável_ basta observar a maneira de entender o mundo e de se conduzir das mais variadas comunidades humanas do planeta. Agregadas às questōes religiosas, ideológicas ou de gênero, estão as posturas diante dos dilemas originados no cotidiano da prática da saúde. Por exemplo, no caso da eutanásia, há quem afirme que é uma prática médica moralmente defensável e há quem a considere imoral e abominável.

Para ele, as sociedades sempre foram, são e serão pluralistas ${ }^{10}$ (ENGELHARDT 1998, p.31) _ difícil uma que não o seja __ razão pela qual encontra-se uma diversidade de sentimentos e crenças morais, diversidade sempre presente, embora oculta. Mas para que se torne claro a idéia de pluralismo e não seja confundida com nenhum sectarismo é preciso estabelecer as diferenças com o universalismo moral e o ecumenismo.

\subsubsection{PLURALISMO NÃO É UNIVERSALISMO MORAL}

O universalismo é o estabelecimento de uma ética universal, essencial (que seja a essência para todas as éticas) congregando

\footnotetext{
10. O autor observa que na Idade Média ocidental, apesar de dominantemente católica romana, incluiam-se populaçōes significativas de judeus, além dos hereges, agnósticos e ateus. Este pluralismo acabou sendo suprimido pela força cultural dominante; fora dessa dominaçăo, é dificil a formação de uma sociedade que năo seja pluralista.
} 
uma comunidade moral de todas as pessoas, independente de preceitos religiosos, culturais, ideológicos, existenciais. É como se, ao se propor uma solução à diversidade moral se procedesse à homogeneização da ética o que seria um reducionismo, pois seria exigir a renúncia de certos valores em nome de adotar outros para um pacto moral onde todos estariam de certo modo contemplados uma renúncia em nome de todos.

\subsubsection{PLURALISMO NÃO É ECUMENISMO}

O ecumenismo é a postura adotada de que toda ética (religiosa ou não) tem algo ou algumas coisas em comum, e portanto tratar-se-ia de reconhecer tais pontos para estabelecer uma ética que pudesse trazer principios que satisfizessem a todos. É a idéia de uma certa concordância moral, que permitiria justificar uma bioética particular e dirigir as questōes da assistência e políticas de saúde com autoridade moral, já que haveria uma 'certa ética básica' que seria comum a todos e poderia portanto, nas decisões em bioética, ser legítima pois consensual_ em relação ao que considerar em determinadas situaçōes ou dilemas (retomando o exemplo citado acima da eutanásia, será que o ecumenismo seria possivel?)

Segundo Engelhardt, este exemplo é uma demonstração de como é difícil aos ecumenistas entender a vida no interior das 
comunidades particulares, e portanto, respeitá-las, pois ao tentarem estabelecer ou encontrar pontos existentes em comum rejeitam a idéia de que cada um é diferente, é peculiar e portanto, não redutivel. Sendo assim, a questão é como estabelecer uma moral comum aos que se estabelecem como diferentes, ou melhor, uma moral secular dos estranhos morais. A dificuldade não é estabelecer um quadro moral que seja a base da bioética entre amigos morais, nem procurar minimizar as diferenças entre os estranhos morais, dizendo que há pelo menos algo em comum ou criar uma moral universal que seja adequada a todos. Mas para ENGELHARDT (1998) é de estabelecer um "quadro moral no qual os indivíduos que pertencem a comunidades morais diversas le nāo partilham uma mesma visão morall ainda podem considerar-se unidos por uma textura moral comum, em uma mesma língua moral" (p.15). O autor, prenuncia assim, a idéia de 'consentimento moral', que será desenvolvida no capítulo IV.

As estruturas sociais morais, constituidas dessa forma, funcionariam de acordo com um procedimento de permissão dos individuos envolvidos, e a autoridade moral só poderia ser obtida a partir da concordância entre estes individuos. Tal moralidade_a moralidade secular_ entre os estranhos morais tem um caráter libertário, se comparada com outros sistemas morais. 
No que diz respeito ao mundo contemporâneo, o secularismo vigente (que trouxe a desestabilização da religião e a marginalização das crenças) assiste a uma redução das religiões a seitas religiosas, no sentido que não há mais a religião ou a igreja de uma sociedade. $\bigcirc$ pluralismo tem sido uma manifestação significativa enquanto produto do secularismo, pois permitiu que numerosas seitas florescessem e se desenvolvessem sem interferência do poder constituido e que os individuos pudessem transitar de uma crença a outra. Em outras palavras, para Engelhardt, a pluralidade de perspectivas e as comunidades morais podem florescer abertamente quando o Estado é secular no sentido de ser moralmente neutro diante das escolhas pacíficas de uma moral concreta particular dos indivíduos da comunidade. Além disso, quando existe uma pluralidade pacífica no seio das comunidades é vantajoso do ponto de vista político para o Estado manter a neutralidade. "A sociedade secular é na prática uma sociedade pluralista."I

As seitas geram bioéticas sectárias, o que em principio é salutar para a sociedade, o fato de se ter uma variedade de pontos de vista morais sob a mesma questão convivendo pacificamente. Mas do ponto de vista da política pública de saúde, como decidir o que é certo ou errado fazer? Como mediar estas perspectivas concorrentes? Diante disso, qual seria o meio de consenso em meio a

" . D. L. Munby, citado por ENGELHARDT (1991, p.150). 
esta diversidade? A questão se coloca em como fornecer uma justificação para solucionar as controvérsias na assistência à saúde, quando os indivíduos não compartilham uma mesma tradição moral e nem entram em acordo sobre os procedimentos a serem adotados para solucionar os problemas que surgem. Vejamos um exemplo: ao se traçar uma política para um hospital que não está alinhado com nenhuma tradição moral em particular, como arbitrar de maneira legítima o conflito que surge de pontos de vista controversos sobre contracepção ou definição de morte? Ou a recusa de hidratação e nutrição artificial? É certo ou errado (bom ou ruim) optar pelo aborto para salvar a vida de uma mãe? Ninguém discordaria que, dependendo do que pregam os judeus, os católicos, os protestante (ou outros adeptos de outras crenças ou ideologias), haveria diferentes respostas para essas questōes. Independente da fé particular, do ponto de vista da justificação, teria sido confrontada uma série de possibilidades de abordagens morais, o que dificultaria a escolha, dado que uma sociedade secular caracterizada por uma pluralidade de pontos de vista, com instituições também seculares, não teria uma autoridade religiosa ou qualquer consideração metafísica eleita como o paradigma das tomadas de decisão.

A bioética secular, enquanto um conjunto de reflexão e investigação, preocupada com problemas como teoria e valor, metafísica, filosofia da biologia, teoria política e social, entre outros, 
procura desenvolver a base para posição crítica dos conceitos de doença e saúde e dos objetivos e conduta na assistência à saúde. É um grande desafio intelectual estruturar uma bioética que, em sendo pluralista, possa atravessar as discussões das diversas comunidades morais, desafio porém, que tem implicações práticas, veja-se por exemplo, a distribuição de recursos em saúde pública, que envolve, em última instância, o uso do poder estatal coercitivo. A principal questão no contexto de uma bioética secular é: como uma autoridade moral pode montar uma política de saúde pública em uma sociedade secular pluralista.

Considerando a sociedade secular pluralista e a inevitável convivência dos estranhos morais, é preciso ressaltar a importância de três idéias na proposta engelhardteana da dinâmica desse relacionamento:

1) que a idéia de 'controvérsia' não diz respeito a uma discordância de opiniões, ou incongruência. Ser controverso significa demonstrar que, com base em valores, o mundo se apresenta diferente, é outro para cada um dos estranhos morais envolvidos. Em outras palavras, controvérsia não é necessariamente oposição; se configura em um reconhecimento da diferença não-redutivel, e isso reflete de maneira legítima a noção de pluralidade: a constatação do descontínuo, do heterogêneo, do diverso. 
2) que a idéia de acordo não se refere a consenso ou a um escrutínio no qual 'a maioria vence'. Acordo é uma forma de solução casuística nas controvérsias entre os estranhos morais. É o esforço de examinar o que pode ser criado a partir de uma situação $X$ de modo que um único objetivo possa ser alcançado: o bem-estar comum e a minimização de problemas na saúde (no caso da assistência). Acordar não é deixar as posições vigentes na comunidade moral de origem nem trocar por valores não-significativos eticamente. Acordar é a disposição para encontrar um plano ou regra de ação na direção daquela situação, naquele momento e frente a tais controvérsias levando-se em conta, principalmente, que isto ocorre em plena relação de 'estranheza moral'.

3) que a idéia de autoridade moral não diz respeito ao papel de porta-voz de um princípio ético ou moral. Está relacionada à representação, de uma orientação circunstancial, cujo único papel é organizar, congregar a proposta de solução moral gerada para o acordo entre os estranhos morais.

(....) autoridade moral secularmente justificável não vem de Deus, nem da visão moral de uma comunidade particular, nem da razāo, mas do consentimento dos individuos. Nessa surdez a Deus e no fracasso da razão os estranhos morais encontram-se como indivíduos (ENGELHARDT 1998, p.132).

Esta pontução de significações pode ser útil na clarificação e compreensão da noção de amigos e estranhos morais inseridas na idéia de pessoalidade, no capítulo III. 


\section{III - A CONCEPÇÃO DE PESSOA PARA ENGELHARDT}

\section{Considerações histórico-filosóficas do conceito de Pessoa'}

As discussões em torno da idéia de pessoa podem ser datadas à época medieval, mas é a partir da filosofia moderna, em especial na filosofia de John Locke (1632-1704) ${ }^{2}$ que encontramos um rico desenvolvimento temático sobre esse assunto _embora não havendo univocidade suficiente para, a partir deste conceito, derivar uma fundamentação da bioética que possa contemplar também seus aspectos decisórios em termos das instituições e das práticas de enfermagem e medicina e da área da saúde de um modo geral.

Na tradição do conceito, então, pode-se verificar que 'pessoas são seres humanos e seres humanos são pessoas'. "O homem é um animal racional e também um animal político", como definia ARISTÓTELES (s/d). Dessa forma, a capacidade de pensamento e a aptidão para viver entre seus semelhantes, procurando estabelecer regras de organização social e política, eram as características do ser humano, da pessoa. Com base nesta identificação, portanto, desenvolvem-se historicamente várias concepções pelas quais passa o conceito de pessoa.

Além do sentido originário da tradição grega de pessoa como máscara, persona, oriundo de sua utilização nas representações trágicas ou cômicas do teatro grego /consistindo na corporificação

\footnotetext{
M. B. Mahowald, "Person", In: Encyclopedia of Bioethics, $2^{\text {nd }}$. ed., 1995, p. 1934-1940.

2 An essay concerning human understanding, escrito em 1690; no cap.27 encontra-se a noção de pessoa para Locke. Tradução portuguesa completa: Ensaio sobre o entendimento humano, Ed. Fundação Calouste Gulbenkian, 1999, 2 V.
} 
da personagem), pelo menos três caracterizações gerais do conceito podem ser apontadas:

1 - Inicialmente, pessoa é utilizado por Santo Agostinho, em De Trinitate (escrito entre 399 e 419)3, para expressar cada uma das partes que compõem a Trindade do catolicismo, que vê a necessidade de explicar a manifestação de Deus sob três maneiras diferentes relacionadas entre si e compostas pela mesma substância.

2 -O período moderno acolhe a proposta cartesiana (DESCARTES $1979 \mathrm{~A}$ e B) do dualismo e o conceito de pessoa passa a ser identificado com o eu-sujeito como consciência (o Cogito: "Penso, logo existo")4. Para Descartes (1596-1650), a vida consciente do eu, o reconhecimento da superveniência do corpo/existência em relação à alma/pensamento estabelece o conceito de pessoa como autoconsciência, ou como consciência de si. Locke (1632-1704) e Leibniz ${ }^{5}$ (1646-1716) seguem nesta direção, guardando-se, evidentemente, as especificidades de cada sistema de pensamento.

3 - Inicia-se com Kanto (1724-1804), seguindo-se com os herdeiros da fenomenologia husserliana _ como Scheler ${ }^{7}$ (1874-1928), Heidegger (1889-1976), Merleau-Ponty9 (1908-1961) _. a idéia de que pessoa se constitui não na interioridade (como em sua identificação com a consciência), mas na relação com o mundo, com o meio ambiente, com o outro. Especificamente na perspectiva fenomenológica podemos verificar a passagem de pessoa (eu) como sujeito para pessoa como intersubjetividade _ constituída à medida em que se dá a inter-relação entre sujeitos no mundo. Tal é,

\footnotetext{
3 . Ver PASCOAES (1945), Santo Agostinho

4 .DESCARTES (1979), Discurso do método (escrito em 1637).

5 . LEINBIZ (1980), Novos ensaios sobre o entendimento humano (escrito em 1765).

6. KANT (1980), Fundamentação da metafísica dos costumes (escrito em 1785).

SCHELER (1955), Le formalisme en éthique et l'éthique matériale des valeurs (escrito em1916).

8. HEIDEGGER (1988), Ser e tempo (escrito em 1927).

${ }^{9}$. MERLEAU-PONTY (1994), Fenomenologia da percepção (escrito em 1945).
} 
por exemplo, a concepção de intersubjetividade em Merleau-Ponty. Apesar das peripécias pelas quais este conceito tem passado no decorrer da história da Filosofia, a ética tradicional_ e grande parte do discurso bioético contemporâneo_ tem insistido em uma identificação entre pessoas e seres humanos que vivem apenas no sentido biológico, encontrando respaldo para este tipo de concepção no princípio da sacralidade da vida, adotando-o como parâmetro de dignidade e respeito à vida. Esta definição genérica de pessoa, apesar de tradicional e intuitiva, vem se chocando com o desenvolvimento da medicina, da enfermagem e das novas tecnologias de assistência à saúde, causando dilemas diante de situações, na maioria das vezes, prementes e urgentes de serem ajuizadas, do ponto de vista ético.

A vida, para Engelhardt, permanece sendo um valor ético, mesmo que sejam diferentes os princípios sob os quais a consideramos, o que não impede o desafio de analisar o que se entende por 'ser pessoa'. Sobre isso ele comenta que

O conceito de santidade da vida refere-se, de forma diferente, ao valor da vida biológica e à dignidade das pessoas. Provavelmente muito do que está associado aos argumentos sobre a santidade da vida, na verdade, refere-se à dignidade da vida das pessoas. $\mathrm{Em}$ qualquer caso, não existe ambigüidade em ser simplesmente 'próvida' ou um defensor da sacralidade da vida_deve-se decidir que tipo de vida se deseja defender e em quê esta defesa se baseia (ENGELHARDT 1988, p.170). 
'Toda pessoa é um ser humano, mas nem todo ser humano é uma pessoa.' Essa asserção poderia enunciar e resumir, em poucas palavras, a posição de Engelhardt em relação à identidade entre pessoa e ser humano. Em uma tentativa de reflexão filosófica sobre esse tema o autor propõe um desdobramento da idéia de pessoa, não se afastando do contexto da saúde para o qual sempre remete as conclusões de sua fundamentação. Assim sendo, e tendo como pressuposto a perspectiva do humanismo secular, para ele a concepção de pessoa pode ser considerada sob dois aspectos:

a)pessoa em sentido estrito

b)pessoa em sentido social

Para a desenvolvimento dessa concepção, em sua argumentação, Engelhardt parte da seguinte condição fundamental:

A vida do organismo humano é tomada como condição necessária para ser uma pessoa, e, por esta razão, permite identificar os casos em que os humanos cessam de ser pessoas (ENGELHARDT 1988. p.170).

É importante destacar esse ponto de partida para diferenciar a postura paradigmática de Engelhardt da postura de outros estudiosos, como TOOLEY (1998), que considera que a questão da pessoalidade 10 possa ser tratada sob dois grandes prismas: a pessoalidade de entidades humanas e a pessoalidade de entidades

\footnotetext{
${ }^{10}$. A palavra "pessoalidade" não existe em português, portanto personhood será por nós traduzida como "pessoalidade" na falta de outra palavra que possa fornecer um sentido mais exato desta expressão; este termo é utilizada por todos os eticistas e bioeticistas de língua inglesa que tratam da concepção de pessoa. Entendemos, então, que pessoalidade seja a condição de alguém ser pessoa, ou os critérios suficientes para esta condição.
} 
não-humanas, incluindo neste último outras mentes, como entidades programáveis, animais ou seres extraterrestres, aos quais Engelhardt menciona de passagem "', mas não problematiza e nem discute.

\section{Estar vivo e ser pessoa: diferença fundamental}

Três pressupostos (ENGELHARDT 1988, p.170); norteiam a idéia de pessoalidade em Engelhardt:

1) ser uma pessoa implica mais que uma vida meramente vegetativa; 2) a vida meramente vegetativa deve ter valor, mas não direitos;

3) em um organismo com funções sensoriais (como as do encéfalo), estas são condições necessárias para a possibilidade de experiência e ação no mundo, isto é, para ser uma pessoa que vive no mundo.

Quando Engelhardt toma como condição de pessoalidade a vida do organismo, retira do contrário dessa asserção o postulado fundamental: se a vida do organismo é necessária para uma pessoa, o conceito de morte - ou seja, quando cessa essa vida do organismo _ é indicativo de quando essa entidade não é mais

\footnotetext{
11. Engelhardt, "The Medicine and the Concept of Person, IN: Goodman (ed.), What is a person? p. 171. Alguns especialistas no assunto trabalham com a viabilidade do paradigma da Filosofia da Mente, cujo pressuposto é a possibilidade de inteligéncia programada, o que resultaria em entidades que tem uma mente artificial, raciocinam e se inserem, em certo sentido, no contexto dos humanos. Para exemplo, veja-se o artigo de Daniel Dennett "Conditions of Personnhood", IN: Goodman (ed.), What is a person?, pp.145-167.
} 
pessoa. O autor lança mão do conceito de morte, vigente na atualidade na área da Saúde, que é o de morte encefálica.

Os três pressupostos acima partem do atual conceito que tem como justificativa as seguintes subdivisões do funcionamento do encéfalo e suas características: a parte superior (cérebro) e a parte inferior (tronco cerebral e cerebelo) (GUYTON \& HALL 2001) 12.

A parte superior (que corresponde aos hemisférios cerebrais) contem as bases fisiológicas não somente das funções mentais superiores, como a autoconsciência (e a consciência rudimentar), a capacidade de deliberação, pensamento e memória, mas também a base de memórias específicas, crenças, preferências, atitudes e traços de personalidade constituindo a originalidade de individualidade que cada um manifesta em si mesmo. A parte inferior controla os processos vitais, como circulação do sangue, o funcionamento do coração e dos rins, inclusive a respiração. A destruição da parte superior (a morte do cérebro) significa, segundo TOOLEY (1998), a destruição da capacidade de qualquer tipo de vida mental, mesmo que a parte inferior permaneça intacta sendo mesmo possivel, em situaçōes de experiências laboratoriais, serem utilizadas células em cultura, pois essas unidades permanecem

\footnotetext{
12 . Segundo os autores a parte superior do cérebro compreende as estruturas suprateutoriais (hemisférios cerebrais e o diencéfalo), e, a parte inferior do cérebro compreende as estruturas infra-teutoriais (tronco cerebral [mesencéfalo, ponte e bulbo] e o cerebelo). $O$ córtex cerebral, pertencente à parte superior do cérebro, é essencial para os processos de pensamento e para a noção de si mesmo.
} 
vivas durante algum tempo, do ponto de vista biológico. O cérebro, sendo parte constitutiva do encéfalo, se tiver cessado o seu funcionamento teríamos algumas capacidades gerais destruídas, mas sobretudo as possibilidades de manifestação de funções de individualidade e, portanto, a perda da identidade de um determinado ser.

Para Engelhardt o conceito norteador de morte a partir do encéfalo gera uma significação filosófica, porque implica discutir a questão da distinção entre vida biológica humana e vida pessoal humana, ou a vida de um organismo humano e a vida de uma pessoa humana. Segundo ele, não há dúvida que a vida biológica pode continuar da morte encefálica, mas o que existe é um corpo funcionando, o qual é apenas uma instância de vida biológica e não se constitui em uma vida humana pessoal. Essa constatação o leva a uma diferenciação entre a condição de estar vivo e a condição de ser pessoa. Essa posição, tomada do ponto de vista filosófico, pressupõe fazer uma distinção entre o ser biológico e o ser pessoa do homem.

\section{Kant e Engelhardt: a distinção entre Coisa e Pessoa e a distinção entre Pessoa e Não-pessoa}

Engelhardt utiliza a terminologia kantiana (e a lógica kantiana) para explicar que a diferença moralmente significativa entre a vida 
biológica e a vida pessoal assenta-se no fato de que a pessoa é "um fim em si mesma". A filosofia de Kant'l3 tem como pressuposto a supremacia da Razão que ele toma como fundamento em sua análise crítica do conhecimento, da moral e das artes; desenvolvida principalmente a partir das "três Críticas"14. Sinteticamente falando, (pois nosso intento neste trabalho não é estudar a filosofia moral kantiana), para Kant as variantes e os motores da ação moral expressam-se através da razão prática, pois a essência ou a natureza humana teriam como base a racionalidade.

Engelhardt utiliza a distinção kantiana entre pessoa e coisa para uma analogia com pessoa e não-pessoa em sua concepção diferencial teórica. A idéia de pessoa está expressa de maneira mais compreensivel na segunda formulação do Imperativo Categórico kantiano, que transcrevemos abaixo:

Age de tal maneira que uses a humanidade, tanto na tua pessoa como na pessoa de qualquer outro, sempre e simultaneamente como fim e nunca simplesmente como meio. (KANT 1980, p.135)

Vejamos uma comparação entre citações de Engelhardt e alguns fragmentos do texto kantiano.

1. Engelhardt:

\footnotetext{
${ }^{13}$. A teoria da moral kantiana encontra-se desenvolvida principalmente em três obras: Fundamentação da Metafísica dos Costumes (1785), Crítica da Razão Prática (1788) e Metafísica dos Costumes (1797).

${ }^{14}$.Crítica da Razão Pura $(1781,1787)$, Crítica da Razão Prática (1788) e Crítica do Juizo (1790).
} 
Kant, por exemplo, argumenta que seres racionais sāo "pessoas, porque sua própria natureza [como seres racionais] aponta-os como um fim em si mesmo" (1988, p.171).

\subsection{Kant:}

Os seres cuja existência depende, não em verdade da nossa vontade, mas da natureza, têm contudo, se são seres irracionais, apenas valor relativo como meios e por isso se chamam coisas, ao passo que os seres racionais se chamam pessoas, porque a sua natureza os distingue já como fins em si mesmos, quer dizer, como algo que nōo pode ser empregado como simples meio e que, por conseguinte, limita nessa medida todo o arbítrio (e é um objeto de respeito): (1980, p.135).

\section{Engelhardt:}

Kant desenvolve uma distinção entre coisas que tem somente "um valor para nós" e pessoas "cuja existência é um fim em si mesma (1988, p.171).

\subsection{Kant:}

Estes não são portanto meros fins subjetivos cuja existência tenha para nós um valor como efeito da nossa ação, mas sim fins objetivos, quer dizer, coisas cuja existência é em si mesma um fim, e um fim tal que se não pode pôr nenhum outro no seu lugar em relação ao qual essas coisas servissem apenas como meios; porque de outro modo nada em parte alguma se encontraria que tivesse valor absoluto. mas se todo o valor fosse condicional, e por conseguinte contingente, em parte alguma se poderia encontrar um princípio prático supremo para a razão (1980, p.135) .

\section{Engelhardt:}

Uma pessoa é [um] sujeito cujas ações são capazes de ser imputadas [quer dizer, alguém que pode agir responsavelmente]. De acordo com isso a personalidade moral é nada mais que a liberdade de um ser racional sob as leis morais (considerando que a personalidade psicológica é meramente a capacidade de alguém ser consciente de sua própria identidade nas várias condições de sua existência...[em contraposição] , uma coisa é o que não é capaz de qualquer imputaçāo [quer dizer, de agir responsavelmente]; (1988, p.172).

\section{A chave para entender a distinção entre coisa e pessoa está}

no que Kant entende como sendo meio e fim; vejamos:

A vontade é concebida como a faculdade de se determinar a si mesmo a agir em conformidade com a representação de certas leis. E uma tal faculdade só se pode encontrar em seres racionais. Ora, aquilo que serve à vontade de princípio objetivo da sua autodeterminação é o fim, este, se é dado pela só razão, tem de ser válido igualmente pra todos os seres racionais. O que, pelo contrário, 
contém apenas o princípio da possibilidade da ação, cujo efeito é um fim, chama-se meio (1980, p.134) .

Se pois deve haver um princípio prático supremo e um imperativo categórico no que respeita à vontade humana, então tem de ser tal que, da representaçāo daquilo que é necessariamente um fim para toda a gente, porque é um fim em si mesmo, faça um princípio objetivo da vontade, que possa por conseguinte servir de lei prática universal. O fundamento deste princípio é: A natureza racional existe como fim em si mesmo. É assim que o homem se representa necessariamente a sua própria existência (...) é também assim que qualquer outro ser racional se representa a sua existência, em virtude exatamente do mesmo princípio racional que é válido para mim; é portanto um princípio objetivo, do qual como princípio prático supremo se tem de poder derivar todas as leis da vontade (1980, p.135).

Para Kant, a vontade é determinada apenas pela razão, e esta sendo racional passa a ser definida como a "relação de uma vontade consigo mesma", e assim sendo, é a razão que, por si só, determina o procedimento. Por procedimento entende-se a ação moral que deve ter um fim em si mesma, quer dizer, o sujeito racional (de posse, por natureza, de sua vontade racional) deve proceder de modo que o desenrolar ou os passos de sua ação sejam um trajeto por si mesmo. Se é um ato do sujeito racional necessariamente não se contará com um outro como instrumento para atingir, efetuar ou praticá-lo, pois estará em conformidade com a lei universal e a vontade racional e deverá, nesse sentido, ser universalizante, tomar o outro da mesma forma como a si mesmo: como sujeito da ação_nesse sentido esse sujeito é pessoa, cujo valor é absoluto, tornando-se um fim em si mesmo. Tudo, ou o outro, que é tomado como um suporte ou objeto para o procedimento ou para a ação, 
visando a atingir a finalidade e não ser a própria finalidade, está excluído da racionalidade, fazendo parte da contingência, adquirindo um valor condicional__um valor para nós"__, o que não condiz com a lei universal. Nesse sentido irracional 'esse objeto' é uma coisa, tornando-se um meio.

De acordo com os fragmentos de Kant, Engelhardt efetua uma aproximação entre a natureza racional de pessoa, (e portanto, com a capacidade de raciocinar) com a capacidade de tomar decisões conscientemente, que segundo ele, os seres autoconscientes e atutodeterminados possuem. Exemplifica dizendo que os "agentes racionais e autoconscientes podem reivindicar tratamento como um fim em si mesmos, porque eles podem ter a experiência de si próprios e podem determinar e controlar as circunstâncias de tal experiência" (ENGELHARDT 1988, p.171).

Para Engelhardt, a autoconsciência e a autodeterminação fazem com que os agentes morais possam reivindicar o direito de serem respeitados como agentes livres, na medida em que o autorespeito e o respeito mútuo levam à autodeterminação do ego. A noção de respeito expressa-se na capacidade de um agente moral elogiar, culpar, censurar e se responsabilizar por suas ações_que é nada mais que o reconhecimento do outro como alguém capaz de se autodeterminar: determinar para si mesmo a direção e as conseqüências de seus atos (isto é, como um fim em si mesmo). Esta 
concepção de autodeterminação está relacionada à idéia kantiana de ser autônomo.

O que é determinado através do outro_o que vale dizer ser utilizado como meio ou instrumento de bem e valor_ não está relacionado à concepção de respeito e nem de agente moral, já que não é reconhecido como agente livre por não deter o autodomínio da ação; é considerado, portanto um ser heterônomo.15

A moralidade, entendida como "um conjunto de fins", prevê uma comunidade constituída de seres autoconscientes_ "baseada, portanto, no autorespeito e não na força, ligados por atos responsáveis e recíproco respeito e autonomia" (ENGELHARDT 1988, p.171).

Com base nesse raciocínio, pode-se concluir então, em que sentido Engelhardt entende a aproximação entre não-pessoa e coisa: é o que não tem a possibilidade da autoconsciência e da autodeterminação no âmbito da ação moral, e portanto não é capaz de qualquer imputação, quer dizer, de agir responsavelmente.

\section{Dois Conceitos de Pessoa em Engelhardt}

O autor ao propor esta discussão enquanto uma reflexão filosófica, esclarece que tem como contexto a área da saúde, à luz

\footnotetext{
15. As nocões kantianas de autonomia e heteronomia encontram-se desenvolvidas em "Que é Esclarecimento" ? (Aufklärung), IN: Immanuel Kant - Textos Seletos, edição bilingue, 1974 .
} 
das questões de vida e morte e do início e do fim da vida; sua concepção abarca dois conceitos de pessoa: em sentido estrito e em sentido social.

\subsection{PESSOA EM SENTIDO ESTRITO}

(....) esse sentido de pessoa eu usarei o termo 'em sentido estrito', o qual é usado para se referir aos agentes autoconscientes e racionais (ENGELHARD 1988, p.175; 1986, p.170 e 174).

Para Engelhardt, as características essenciais de pessoas em sentido estrito são a autoconsciência e a racionalidade__inspiradas na concepção kantiana, conforme apresentado na seção anterior.

Esse sentido de pessoa é usado para identificar os agentes morais; os quais podem ser definidos como portadores vivos e individuais de direitos e deveres. A idéia de agentes morais, assim colocada, seleciona entidades que participam do contexto e da linguagem moral, na medida em que esse tipo particular de individuo pode fazer ponderações e apreciações, emitir julgamentos, apresentar exigências, e, ter estas alegações e reivindicações respeitadas. Ainda com base na definição acima, o termo pessoa é aplicado a agentes ou seres autoconscientes e por isso a "adultos humanos normais" (ENGELHARDT 1988, p.175) _os quais são capazes de ter a dimensão de suas ações morais e portanto a capacidade de optar, escolher, aceitar, rejeitar, propor e responder por elas. 
Para Engelhardt a racionalidade e a autoconsciência delimitam a concepção de pessoa em sentido estrito, a qual poderia ser estendida até para agentes autoconscientes não-humanos, caso se viesse a reconhecê-los. Quer dizer, esse conceito restringe-se à vida biológica humana autoconsciente e racional, e também a agentes autoconscientes de qualquer espécie. 10 autor não se estende quanto ao mérito dessa observação; entendemos que a utilizou mais em um sentido lógico).

A pergunta que se segue, após essa conceituação é a seguinte: Como consideraríamos os outros tipos de vida humana nãoautoconscientes e tampouco ainda conscientes? Ao se indagar sobre isso Engelhardt tem em mente as crianças, os humanos inconscientes (por ex., os comatosos) e a vida humana nãoconsciente (fetos, recém-nascidos). Para ele, essas entidades não podem ser classificadas, do ponto de vista conceitual, como pessoas em sentido estrito, pela própria condição limitada de exercer ou de Ihes faltar a consciência.

Mas justamente considerando o universo das ações em Saúde, de imediato, percebe-se que esse conceito se apresenta incompleto para entender outras instâncias de vida. Exatamente por reconhecer a dificuldade (tanto teórica quanto prática) de pensar a diferença entre Pessoa e Não-pessoa, Engelhardt propōe um segundo conceito: Pessoa em sentido social, que delimitaremos em seguida. 


\subsection{PESSOA EM SENTIDO SOCIAL}

Engelhardt chama também de papel social de pessoa, que

(....) é evocado quando certas instâncias de vida biológica humana são tratadas como se fossem rigorosamente pessoas, mesmo não sendo. (ENGELHARDT 1988, p.175)

A dificuldade em se adotar unicamente o conceito de pessoa em sentido estrito para a idéia de Pessoa é porque existem entidades que não se caracterizam pela racionalidade e nem pela autoconsciência _ _ e, portanto, não são entidades consideradas agentes morais, portadores de deveres e direitos _ mas são considerados como tal em várias estruturas das relações humanas. Não podem ser entendidas sob o conceito de pessoa em sentido estrito mas podem fazer parte do discurso da pessoalidade e ser compreendidas sob o conceito de pessoa em sentido social.

Tratar a vida biológica como se fosse pessoa, para Engelhardt, significa atribuir as mesmas condições de vivência e sentido moral que as pessoas em sentido estrito possuem por natureza. Pessoas em sentido social caracterizam-se pelos humanos nos quais inexistem ou são questionáveis os elementos essenciais do primeiro conceito: ou por terem deixado de ser autoconscientes, ou porque não atingiram o desenvolvimento mental, cognitivo e físico na escala humana. A esta categorização pertencem as crianças, os idosos, os retardados mentais e os doentes mentais severos_colocando sob questionamento os fetos. 
Esse conceito é concebido para o entendimento do estatuto de entidades que, não sendo pessoas em sentido estrito, atribui-se a elas o papel de pessoa pelo grupo familiar ou social, na medida em que a relação social está ou esteve de alguma maneira presente. É este o significado de "social" considerado pelo autor na idéia de sentido social de pessoa.

\subsubsection{Crianças}

Ao se considerar a vida da criança, troca-se o significado do ser puramente biológico pelo significado social, com base na situação de que ela é um ser humano capaz de se engajar minimamente em uma interação social. Veja-se, por exemplo, o típico relacionamento familiar, principalmente, dos pais em relação às crianças, no qual esta é tratada como se tivesse vontades e desejos de uma pessoa: seus gritos e murmúrios são considerados ou interpretados como se fossem pedidos de comida, atenção, cuidado, etc. O bebê é inserido em uma estrutura social _é portanto socializado__e 'torna-se' uma criança; é vista como se reagisse de maneira semelhante a outros seres sociais que têm a noção de seus papéis no contexto social, de posse dos quais elas agem e reagem, com a diferença que as crianças não têm essa noção, mas são tidas como se tivessem. 
No entanto, Engelhardt desconsidera como pessoas em sentido social as crianças anencefálicas e os adultos com morte encefálica, explicando que estão desqualificados para o papel de pessoa porque Ihes "falta a habilidade para se engajar e interagir minimamente do ponto de visła social" (ENGELHARDT 1988, p.175), já que esse uso de pessoa é empregado para instâncias específicas da vida biológica enredadas em papéis sociais, como se fossem pessoas.

Para Engelhardt, a justificativa para o conceito de pessoa em sentido social relativo às crianças assenta-se na dificuldade em determinar, na ontogenia humana, quando as pessoas se fornam rigorosamente pessoas, pois os seres humanos tornam-se pessoas em sentido estrito _ autoconscientes e com capacidade de racionalização _ algum tempo após o nascimento; ou, em outros termos, a dificuldade está em determinar quando se inicia a pessoalidade em sentido estrito.

A classificação de crianças no sentido social de pessoa é pertinente e torna-se um valor especial na medida em que essa prática em relação à criança é um meio de preservar a confiança na família, de alimentar as virtudes de cuidado e solicitude para com um ser frágil e de assegurar o desenvolvimento saudável da criança. Do ponto de vista da sociedade há uma postura de valorização ao "proteger qualquer coisa que pareça e aja de uma maneira 
razoavelmente humana, particularmente quando cumpre um papel social humano estabelecido". (ENGELHARDT 1988, p.175)

Em que sentido considerar os adolescentes? Para Engelhardt, embora eles não possuam o status dos bebês e nem das crianças, ainda assim não podem ser vistos como tendo a mesma condição dos adultos de dignidade de agentes livres. Nesse período de vida, ainda é pequena a possibilidade da livre escolha pela incompletude da capacidade de autoconsciência e da responsabilidade limitada para o ato moral.

Essa concepção de pessoa em sentido social permite que os direitos da pessoa sejam estendidos ou imputados às formas de vida humana que apresentem o minimo de interação social, mesmo não se constituindo agentes morais. Esse interesse em proteger e resguardar o ser que possa representar o papel de pessoa gera valorização, fortalecendo, no geral, a posição social de pessoas.

\subsubsection{Idosos e Doenca Mental}

O conceito de pessoa em sentido social também está na base da consideração e do tratamento dos idosos, dos retardados mentais e dos doentes mentais severos. Segundo Engelhardt, do mesmo modo que as crianças, eles são seres humanos, mas não agentes morais (portadores de direitos e deveres). A diferença entre conceber alguém como pessoa em sentido estrito e pessoa em sentido social é 
que aos últimos podem ser atribuídos direitos, mas não deveres_ quer dizer, são tratados com respeito, mas não são moralmente responsáveis por suas ações, já que não lhe são imputados deveres.

A justificativa para o conceito de pessoa em sentido social, relativo aos idosos e às pessoas com debilidade e transtornos mentais severos, baseia-se na dificuldade em determinar quanto se deixa de ser uma pessoa em sentido estrito. Quer dizer, quanto tempo alguém que avança em idade será capaz de assumir suas decisões com autoconsciência e praticar ações responsáveis, e, quanto aos doentes mentais, baseia-se no fato da intermitente ou inexistente competência para a responsabilidade e imputabilidade. Socialmente, o tratamento afável para com os mais fracos é uma prática estabelecida, no sentido de protegê-los la proteção também é uma preocupação em relação às crianças) de maus-tratos inadvertidos de pessoas em sentido estrito.

Para Engelhardt, o sentido social de pessoa é uma maneira de conceber algumas pessoas, mas também uma forma de tratar certas instâncias de vida humana para que o modo de viver das pessoas em sentido estrito possa ser exercido plenamente em todas suas caracterizações. 


\subsubsection{Fetos}

Engelhardt faz um questionamento em torno da possibilidade de classificação de fetos como pessoas em sentido social. Fetos estão desqualificados para a pessoalidade, pois são uma instância de vida biológica humana e desse modo não se caracterizam como pessoas. Não se pode considerar o feto no mesmo nível de comparação que a criança; esta existe enquanto ser social: nascida, tem uma identidade, um papel social (na familia e na comunidade) e uma potencialidade para tornar-se, através de seu desenvolvimento físico e psicológico, uma pessoa em sentido, estrito __por isso a consideramos como pessoa em sentido social.

feto, mesmo sendo um organismo humano com probabilidade genética e orgânica de continuidade como pessoa humana, ainda assim não seria uma pessoa, nem em sentido social e muito menos em sentido estrito, ou seja, não apresenta qualquer inserção ou interação social e nem capacidade racional. Para Engelhardt, os fetos não se encontram enredados em papéis sociais como os bebês e as crianças, veja-se por exemplo, a relação biológica mãe-feto e a relação social mãe-criança: a relação biológica continua existindo se houver ou não o reconhecimento social do feto, já a relação mãe-criança não existirá se não houver seu reconhecimento social. 
O autor lança mão de uma comparação como exemplo para demonstrar seu argumento: ao nos reportarmos a um homem morto, sabemos ao que nos referimos, de 'quem' falamos, da pessoa que se conheceu antes de morrer; ao falarmos do feto não existe um 'quem', um alguém ao qual nos referirmos. A questão da identidade, no caso da engenharia genética, e principalmente da individualidade reforçam também este ponto de vista da desqualificação do feto para a pessoalidade, já que muitas vezes ao se implantar um zigoto este se subdivide em dois_ pessoas não se subdividem em outras completas e idênticas a si. Esta perspectiva também vai ao encontro dos argumentos de defesa do uso de dispositivos de contracepção e da discussão em torno da validade e da legitimidade do aborto_ evitar ou interromper uma gravidez não implicaria em causar dano a uma pessoa.

Para reforçar sua perspectiva em relação à pessoalidade dos fetos e das crianças, Engelhardt lança mão do argumento da potencialidade, segundo ele mesmo talvez um tanto falho, pois como discutir 'potencialidade para ser pessoa' se não partimos do pressuposto que são pessoas _ mas ainda assim um argumento forte para uma melhor compreensão dessa posição. Diz ele: a potencialidade de $X$ para tornar-se $Y$ pode nos levar a valorizar altamente $X$ porque valorizamos muito $Y$, mas até que $X$ não seja $Y$ não tem valor de $Y_{\text {_ }}$ em outros termos, pode-se dar valor a uma 
dúzia de ovos ou a um punhado de sementes que poderão se tornar galinhas ou árvores de carvalho, mas uma dúzia de ovos não é uma bando de galinhas e um punhado de sementes não é um bosque de carvalhos. (ENGELHARDT 1988, p.176)

Não é nosso objetivo nesse estudo discutir sobre o aborto, mas é válido registrar a posição de ENGELHARDT (1998, p.310-313) sobre o assunto, sob a perspectiva do respeito à autonomia. Para ele a mulher teria o direito de optar livremente a respeito de seu corpo enquanto agente moral, e assim sendo, considera que os abortos precoces teriam que ser permitidos já que, desse modo a mulher, autodeterminada, saberia discernir sobre o desejo de ser mãe ou não.

\section{Amigos morais e Estranhos morais}

Os conceitos básicos para uma compreensão precisa da proposta engelhardteana são: estranhos morais e moralidade essencial, comparados com amigos morais e moralidade continuísta. (ENGELHARDT 1998, p.32)

A idéia de ética essencial, já desenvolvida no item anterior, pode ser referência para a compreensão de 'moralidade essencial'. Essa perfaz a totalidade de valores, princípios e regras morais (explícitas ou não) para julgar o certo e errado, o bom e mau, além 
de alguma exigência para que não se usem as pessoas sem sua autorização.

Amigos morais são pessoas que compartilham uma moralidade essencial, de maneira que podem resolver as controvérsias morais por meio de um argumento moral sadio ou recorrendo a uma autoridade para resolvê-las. Estranhos morais são pessoas que não compartilham suficientemente regras morais para resolver as controvérsias por meio de uma sadia argumentação racional, ou que não têm compromisso com uma autoridade moral para resolvê-las. Os estranhos morais necessitam resolver as controvérsias através de um acordo comum, pois nāo compartilham entre si uma perspectiva moral (regras de evidência e inferência) que thes permita descobrir soluções satisfatórias para as questões morais discordantes ou que alguma autoridade possa dar à orientação moral essencial. A 'moralidade continuísta' é aquela que une os estranhos morais: as pessoas transmitem os esforços comuns através de um acordo a uma autoridade moral de seu consentimento.

autor, no intuito de caracterizar melhor a idéia de amigos morais e estranhos morais, faz uma distinção entre comunidades e sociedade. O termo 'comunidade' será por ele usado para identificar um corpo de pessoas unidos por uma tradição ou práticas morais comuns, que thes permitam colaborar como amigos morais; já o termo 'sociedade' identificará uma associação que envolve 
indivíduos que se encontram em comunidades morais diversas. Embora possam colaborar em uma associação comum como cidadãos (sendo estranhos morais), estão alinhados entre amigos morais que compartilham as mesmas premissas éticas.

Segundo Engelhardt, os estranhos morais necessariamente não são estranhos entre si: podem ser os melhores amigos afetivos, mas ao adotarem uma escala diferente de valores morais se transformarāo em estranhos morais. Também não precisam ser inescrutáveis entre si e podem até ter os mesmos valores com uma ordenação diferente entre eles, o que é suficiente para gerar posturas de orientação moral diversas ou antagônicas em muitas situações. Os estranhos morais consideram-se, uns aos outros, mal orientados ou enganados, mas não se vêem como alienígenas. "Ser estranho moral é habitar em um mundo diferente." (ENGELHARDT 1998, p.124)

O entendimento é possivel entre comunidades morais divergentes, mesmo quando os valores estão em jogo; por exemplo os batistas conseguem compreender os muçulmanos dedicados e estes conseguem compreender os socialistas ateus. "Entendendo-se uns aos outros, eles podem ao mesmo tempo discordar uns dos outros, embora sendo até parceiros em determinadas áreas ou em certos empreendimentos públicos." (ENGELHARDT 1998, p.33)

Deve-se considerar que as comunidades morais não são todas fechadas como os mosteiros ou como os grupos ideologicamente 
comprometidos; e os indivíduos não vivem suas vidas voltados sempre para suas comunidades morais_ descobrem-se, em muitas situações, sendo ao mesmo tempo, amigos e estranhos morais em relação às mesmas pessoas. Em outras palavras, em certas discussões as pessoas serão capazes de solucionar questões através de argumentos racionais ou de uma autoridade moral reconhecida; em outras, a solução será possivel apenas através de um acordo. Mesmo assim, a estranheza dos estranhos morais não exige que "o outro seja incompreensivelmente outro, mas apenas que seja visto como outro por causa das diferenças em compromissos morais. " (ENGELHARDT 1998, p.124)

Desse modo, considerando a vida das pessoas, percebe-se que a moralidade está disponível em dois níveis: a moralidade essencial dos amigos morais e a moralidade continuísta que une os estranhos morais. Em termos de realidade, não é possivel esperar que a sociedade como um todo ou o Estado constitua $\underline{\mathrm{a}}$ comunidade moral, e que esta fosse o fundamento da bioética secular. Isso resultaria em uma repressão ao direito secular da prática moral das inúmeras comunidades originadas pela própria lógica do secularismo. Não que a diversidade seja totalmente benemérita em si mesma e que não contenha contradições, mas o Estado secular jamais poderá reservar a si o papel do Deus que arbitra através de sua providência o que os individuos devem fazer. A omissão, nesse caso, 
é salutar e necessária tornando-se a característica legítima de uma posição politeísta.

\subsection{ASSISTÊNCIA À SAÚDE, SECULARISMO E BIOÉTICA}

Não é tão fácil identificar os estranhos morais _ já que sua estranheza nem é tão estranha assim _ e que as moralidades dos amigos morais nem sempre geram reivindicações absolutas ou de mesmo caráter e intensidade, mesmo continuando a oferecer uma essência _ o que a moralidade dos estranhos morais não pode proporcionar. Para Engelhardt, principalmente ao se vivenciarem situações na assistência à saúde, a moralidade vivida por muitos fica distante do compromisso moral anunciado por aquele grupo religioso ou ideológico particular. Podemos perceber que é preciso prever a existência de várias bioéticas e várias bioéticas essenciais: a que exige o compromisso supremo com os valores corretos da comunidade, a que oferece simplesmente uma interpretação essencial sobre a vida, o sofrimento e a assistência à saúde e a bioética secular.

No contexto da saúde, consideremos também as duas dimensões da moralidade em que vivem as pessoas: a essencial e a continuísta. Na primeira, a das comunidades particulares, é possível alcançar uma interpretação da essência de uma vida boa, das obrigações morais, inclusive de vícios e virtudes; é esta que pode 
estabelecer os direitos seculares dos pacientes, inclusive até em recusar o tratamento que salva suas vidas. A segunda dimensão indicará quando a pessoa deve exercer esse direito. Alguns pontos de tensão só podem ser compreendidos no interior de visōes morais particulares:

-entre a ética secular (que oferece um procedimento) e a ética e a bioética de comunidades morais particulares lque oferecem a essência de um ato através da interpretação ortodoxa de um valor): -entre a ética que, em suas bases conceituais, apresenta o respeito pela liberdade dos agentes morais como fonte de permissão ou da autoridade moral secular e a ética e a bioética que compreendem a busca de bens e o respeito às obrigações morais.

Os dilemas bioéticos revelam importantes pontos de tensão dentro da vida moral, não apenas entre a moralidade essencial e a moralidade secular. (....) Os médicos e enfermeiros estão sempre diante de conflitos entre respeitar a liberdade dos pacientes e fazer o que é melhor para eles. (...) os profissionais da saúde precisam tornar-se especialistas em apresentar aos pacientes o caráter dessas tensões e suas implicações morais (ENGELHARDT 1998, p.128).

A conseqüencia deste tipo de tensão pode ser expressa através do seguinte comentário: "O paciente tem o direito de fazer isso, mas está errado". Vejamos um exemplo: um médico ateu na Holanda pode considerar a recusa de suicídio assistido pelo médico, da parte de um paciente agônico terminal, como incompreensivel quanto aos compromissos morais de um médico, pois nesse caso, o 
ateu vive em um mundo moral estranho ao crente, o qual suporta a doença com submissão ou como punição de Deus por algum pecado cometido.

É importante ressaltar que a estranheza dos estranhos morais não se manifesta somente no encontro entre religiosos e ateus. Muitas vezes a visão de mundo ou a maneira de considerar vários assuntos ou situações são bastante diferentes, não envolvendo, necessariamente, questões de crenças. Vejamos, por exemplo, dois ateus opinando sobre a maternidade de aluguel: um a considera uma exploração mercantilista, pois para ele o corpo humano é dotado de condições especiais; outro a considera perfeitamente normal, como uma transação de compra e venda de serviços de reprodução, essencialmente igual à compra e venda da arte de uma bailarina ou de um cantor. Certamente, essa discussão se transformaria em uma controvérsia insolúvel, se prosseguissem nesse tom; é justamente essa incapacidade de solucionar as controvérsias morais (exceto pelo acordo) que assinala a distância entre os estranhos morais. Na perspectiva de Engelhardt, "somente a moralidade secular sem essência pode fechar esses abismos e permitir a colaboração, na ausência de acordo moral essencial" (ENGELHARDT 1998, p.124).

Médicos, enfermeiros e outros profissionais da área da saúde desempenham papéis morais complexos pela diversidade da 
moralidade reinante. Eles vivem sua vida moral dentro de pelo menos dois mundos: o primeiro é o da comunidade moral que fornece seus valores pessoais e o significado e conteúdo destes valores; o segundo é o do contexto moral pluralista sob uma textura moral secular que abrange outras comunidades (além da sua) e une indivíduos de comunidades morais díspares. Examinemos outro exemplo apresentado por Engelhardt: o ginecologista católico romano que se opõe à contracepção e ao aborto precisará aceitar o fato de que as mulheres terão direito moral pluralista secular ao aborto, apesar de, moralmente, o aborto ser errado. Segundo o autor, os profissionais adeptos dessa mesma visão deverão advertir o paciente sobre isso e garantir legalmente seu direito de não colaborar com $\circ$ que consideram imoral_é uma atitude necessária frente a um paciente estranho moralmente.

As regras burocráticas funcionam para proteger os direitos, quando os indivíduos se encontram como estranhos morais, como costuma acontecer em sociedades pluralistas seculares. São absolutamente necessárias quando não está muito claro que as pessoas envolvidas compartilham as mesmas suposições sobre os melhores interesses a ser garantidos por intervenções e pesquisas médicas_ um exemplo deste tipo de garantia é o consentimento livre e informado. Por uma questão de vivência e formação os profissionais de saúde têm muito conhecimento a respeito das 
características e conseqüências de várias doenças, dos tratamentos de risco, do sofrimento e da morte. Cabe a eles desempenhar o papel de apresentadores de tais circunstâncias, mas com o reconhecimento da rede moral existente subjacente à situação, não somente à moral secular mas também à moralidade das comunidades particulares, ou dos pacientes em particular.

\section{Vida: Valor e Dignidade}

Voltar-se para a reflexão sobre o valor e dignidade da vida, para Engelhardt, envolve contribuir para o debate em Bioética acerca da sacralidade ou santidade da vida. Para ele, pensar em que sentido a vida é sagrada envolve pensar que tipo de vida humana tem somente valor e que tipo se atribui dignidade e valor, porque nem toda vida é sagrada da mesma forma, e portanto a concepção de vida sagrada talvez deva ser pensada em termos de valor e dignidade e ao invés do termo univoco de santidade.

(....) não existe uma maneira universal de falar da santidade da vida: algumas vidas (vida pessoal) têm dignidade, toda vida pode ter valor e, a vida biológica humana que representa o papel social de pessoa tem um valor especial e é tratada como vida pessoal humana (ENGELHARDT 1988, p.181).

Para ele, pensar as instâncias de vida biológica humana nestes termos, ao menos contribui para uma clarificação no âmbito da 
saúde, distinção conceitual esta que se reflete de grande importância na prática. "Afinal de contas, a medicina não é somente um empreendimento de preservação da vida humana_se fosse o caso a medicina confundiria cultura de células humanas com pacientes que são pessoas"(ENGELHARDT 1988, p.173) _ _e isso envolve focar a questão de quando as pessoas começam e terminam. Assim sendo, do ponto de vista prático, esperma humano, óvulos humanos, cultura de células humanas, zigotos humanos, embriōes e fetos podem ter valor, mas thes falta dignidade; as crianças demonstram ser pessoas em alguns aspectos e os adultos humanos normais demonstram ser pessoas.

Tentar pensar em categorias da pessoalidade talvez possa enriquecer um pouco o debate em torno da questão. Os dilemas éticos atuais referentes aos desenvolvimentos recentes da genética, da biomedicina (clonagem entre outros temas) teriam, certamente, mais um instrumental conceitual para a imprescindivel discussão e reflexão bioética a respeito dos questionamentos sobre os limites da manipulação da vida e da pessoa humana no âmbito da tecnologia médica.

A delimitação do conceito de pessoa em sentido estrito a partir da racionalidade e da autoconsciência, enquanto o agente moral que faz opções e se responsabiliza por elas, e, a teoria dos estranhos 
morais, levam-nos a refletir sobre algumas implicaçōes para a idéia de autonomia e consciência, o que faremos no capítulo IV. 


\section{IV - Autonomia e Consciência: Algumas questōes}

\section{Autonomia como consentimento: Engelhardt}

Etimologicamente autonomia é uma palavra de origem grega composta por autos, que significa 'o mesmo', 'ele mesmo', 'por si mesmo', e por nomos significando 'instituição', 'lei', 'norma', 'convenção' ou 'uso'. Foi usada na Antigüidade para designar a situação das cidades-Estado gregas que mantinham uma independência política e administrativa entre si. Portanto, autonomia quer dizer a capacidade do homem ou de uma coletividade em "dar-se as próprias leis", e também "a condição de uma coletividade ou de uma pessoa determinar a ela mesma a lei a qual se submete" (SCHRAMM 1998, p.30; LALANDE 1999).

Em sua origem, historicamente o conceito de autonomia referiu-se a uma coletividade, como no caso das cidades-Estado, e foi a partir do lluminismo que adquiriu um sentido referido a individuos, principalmente com proposta kantiana do esclarecimento (Aufklärung). KANT (1974) reflete sobre a necessidade do homem abdicar da 'menoridade' e assumir a 'maioridade', colocando o exercício da razão como sendo a única forma de se agir autonomamente. Ou seja, é a idéia de que a humanidade atinge a 
maturidade quando obedece às normas de sua própria razão. Ao formular uma teoria da moral, Kant propõe a razão prática como a fonte das normas e leis da razão humana _ universais, racionais e da ordem do 'dever ser'.

Embora os significados estejam relacionados, há uma diferença entre o conceito de autonomia (acima explicado) e o princípio de autonomia. "Principia indicam a fonte, o começo, o início ou as origens de áreas particulares da vida moral" (ENGELHARDT 1998, p.132). O princípio determina o norte da ação moral tendo como base os valores; por exemplo, para o princípio da sacralidade da vida, a vida é um valor e o princípio fornece em que sentido ela é valorizada _ nesse caso, a vida deve ser valorizada enquanto algo sagrado, intocável, inviolável. Com a crise da ética na época contemporânea, com o surgimento da metaética (com base na filosofia analítica, examina os conteúdos e as formas dos enunciados éticos) e com o advento da ética aplicada, os princípios deixaram de ser classicamente considerados universais, e passaram a ser tomados na condição prima facie, quer dizer, não absolutizados e dependentes dos contextos em que acontecem as situações de conflito moral (SCHRAMM 1998).

Essa concepção principialista prima facie é a proposta de BEAUCHAMPS \& CHILDRESS (1989) que concebem os quatro princípios tradicionais da bioética, cuja teoria é denominada principialismo. 
São eles: autonomia, beneficência, não-maleficência e justiça. $\bigcirc$ princípio de autonomia é entendido como o princípio do respeito pela autonomia e para os autores, em biomedicina, diz respeito às açōes autônomas (de escolha) do paciente ou do sujeito de pesquisa, e envolvem as condições do exercício da autonomia e de consentimento.

Segundo SCHRAMM (1998), é a partir do surgimento da bioética (depois de 1960) que o princípio de respeito da autonomia pessoal vem a ser utilizado como um dos principais dispositivos na filosofia moral, nas situações de choque de interesses e valores no âmbito da moralidade secular ou das sociedades secularizadas e pluralistas.

Engelhardt explicital que entende o princípio de autonomia como consentimento e permissão. O princípio do consentimento é exercido num contexto moral em que as pessoas se encontram como estranhos morais, porque não conseguem resolver as controvérsias morais para agir em função do bem-estar comum. Ou seja, quando as premissas de cada um e os argumentos racionais são insuficientes para dar uma solução às questōes da vida moral, só resta estabelecer uma textura comum de moralidade para que a

\footnotetext{
1. Na $1^{a}$ ed. de The Foundatios of Bioethics (p.66-103) o autor utiliza a denominação "princípio de autonomia" ao conceber as situaçóes de moralidade secular envolvendo os estranhos morais que requerem o acordo; na $2^{\circ}$ ed. de 1996 ele faz uma revisão substituindo-o pelo "principio de consentimento" ou "principio de permissão" (trad. brasileira, 1998, p.131-168).
} 
propriedade ou impropriedade de uma ação particular possa ser resolvida intersubjetivamente através do acordo mútuo. Para que haja uma ação conjunta, nesse caso, é necessário que se constitua uma autoridade moral comum que será derivada da permissão entre os envolvidos. Essa é a idéia de consenso para Engelhardt.

A idéia de intersubjetividade, nessa questão em particular, diz respeito a uma prática entre os sujeitos baseada no respeito mútuo para aceitar, optar ou recusar uma perspectiva que possa eleger uma postura acordada sobre um ponto de vista moral, visando a uma moralidade concreta. O ponto principal será o respeito mútuo na negociação comum e o interesse em uma perspectiva comum de moralidade concreta na direção do bem-estar das pessoas, regidos pelo consentimento mútuo. Para ENGELHARDT (1998)

se em circunstâncias seculares, uma pessoa não pode obter autoridade moral de Deus ou da razão, tal autoridade só pode ser obtida a partir da concordância entre os indivíduos. Como as únicas estruturas sociais moralmente autorizadas em tais circunstâncias são aquelas estabelecidas com a permissão dos indivíduos envolvidos, a moralidade que une os estranhos morais tem um caráter inevitavelmente libertário (p.17).

O autor esclarece que, embora o consentimento ou a permissão não sejam desprovidos de liberdade ou de escolha individual, o caráter libertário não significa a defesa da autonomia ou da liberdade como valor ou princípio moral, na medida em que nem uma nem outra se 
constituem essências da moralidade, e que seriam inevitavelmente limitadas pelo ato de consentir, de cada uma das partes, em ser governadas - daí o caráter libertário e não um exercício de autonomia e liberdade plenas. "Nessa surdez a Deus e no fracasso da razão os estranhos morais encontram-se como indivíduos", adotando uma autoridade moral secularmente justificável.

A partir dessa perspectiva, Engelhardt coloca que os profissionais da saúde, em sua prática de assistência, não deveriam tratar, fazer experiências ou cuidar de um paciente lque estivesse de posse de sua competêncial sem sua permissão. Quando estes profissionais agem de maneira contrária habitualmente justificam suas atitudes pelo princípio da beneficência o ensejo de fazer o bem ou o melhor para o paciente. Mas para o autor, o princípio do consentimento se sobrepõe ao primeiro, pois existe uma dificuldade anterior que é decidir sobre que tipo ou qual bem deve ser feito__ 0 bem tem conteúdos diferentes e, o bem a ser considerado para alguém pode ser visto como prejudicial para o outra pessoa, mesmo ambos referindo-se a um mesmo ato. A interpretação da vida boa ou do melhor tratamento pode ser tirânica.

"Faça o bem do outro", poderia ser a máxima adotada, mas tal incondicionalidade enfraquece o sentido da ação beneficente, dado que a obrigação em proporcionar o bem (como dita este princípio) se esvaziaria, pois que não se elegeram os parâmetros 
desse bem. Na prática, o consentimento deve não somente estar junto como preceder a beneficência. Há que se obter a permissão para a ação e respeitá-la, com alguma condição que propicie a ação beneficente, tais como:

a) se o bem não for reconhecido como um dano ou prejuízo, ou b) que a provisão deste bem não está errada em algum sentido. É uma forma de se admitir a moralidade do respeito mútuo, de se evitar o paternalismo e implementar a prática da escolha, da recusa e do acordo mútuo. ENGELHARDT (1998, p.148) nos dá o seguinte exemplo: considere-se o médico consultado por uma adolescente de 16 anos que solicita informações contraceptivas para sua vida sexual; este profissional é da opinião que a atividade sexual não é boa para essa faixa etária e que fornecer tais informaçōes poderia contribuir para um aumento dessa atividade. Mas ao mesmo tempo pode avaliar as conseqüências de uma gravidez não-desejada e pesar que $o$ fornecimento de informações $e$ de material contraceptivos seria um ato de beneficência. Quer dizer, existe um espaço para aceitação do médico em respeitar a decisão do cliente que pode confluir com a opção do cliente, e assim sendo, o profissional pode julgar 0 ato de dar ao paciente o tipo de tratamento que este escolher sem deixar de levar em consideração o seu próprio contexto de beneficência. 
Para ENGELHARDT (1998), "a moralidade em uma sociedade pluralista secular é a prática de fazer o bem dentro das fronteiras da autoridade moral em comunidades com visōes morais diferentes" (p.148), e assim sendo o princípio do consentimento, a priori, aponta para a própria fronteira de 'todas' as comunidades morais. Nesse contexto, o que se apresenta é o princípio negativo de tolerância, no sentido que tolerar é 'não agir' quando se optaria por uma atitude diferente, ao priorizar o valor da permissão e na adoção do respeito mútuo.

Na moralidade do respeito mútuo, o princípio do consentimento necessita ser aceito nāo somente do nos considerarmos dignos de respeito, mas também ao considerar as pessoas como capazes de, rejeitar ou aceitar escolhas, e serem respeitadas por isso; ou como indivíduos que reconhecem a autoridade moral em uma época pós-moderna, pluralista e secular, na qual não são válidas as premissas religiosas, metafísicas ou ideológicas particulares.

No caso de haver o não-cumprimento do acordo mútuo, quer dizer, uma violação à permissão concedida e acordada, o indivíduo pode ser excluido da comunidade pacífica na qual todos correspondem ao que foi contratado, sendo previsto até, em casos extremos o uso da força, de modo defensivo, contra o indivíduo transgressor. Se o individuo não participa do mundo do respeito 
(mesmo que seja em nome da beneficência) resta o uso da força, que aqui significa forçar a adoção do ponto de vista moral pela imposição. "Violar o princípio do consentimento prevê a restrição da autonomia do ofensor e violar o princípio da beneficência elimina o direito do ofensor a qualquer tipo de beneficência rejeitada para outros." (ENGELHARDT 1998, p.144)

Por essa razão, para Engelhardt, o princípio do consentimento se justifica através da moralidade do respeito mútuo e não está delimitado pela liberdade como valor, mas centrado nas pessoas como fonte de autoridade moral secular.

Pode-se concluir que o princípio de autonomia como consenso, para Engelhardt, se constitui a partir da própria natureza controvertida da bioética secular e visa a enaltecer uma moral compartilhada e vinculada dos que queiram resolver seus conflitos com os outros com base em uma moral comum. Assim sendo, no quadro da moralidade secular pluralista dos estranhos morais, as pessoas são importantes justamente porque são elas que decidem aceitar (ou não) aderir ao consenso, e, Engelhardt, ao ressaltar esse ponto, parece que deixa para segundo plano a discussão sobre o valor e a dignidade das pessoas. Transcrevemos a seguir (ENGELHARDT 1998, p.158) a súmula do princípio do consentimento elaborada pelo autor, na qual ele procura mostrar a abrangência deste princípio. 


\section{PRINCÍPIO DO CONSENTIMENTO}

A autoridade para as ações envolvendo outros em uma sociedade pluralista secular é derivada de sua permissão. Como conseqüência,

i.sem essa permissão ou consentimento não há autoridade;

ii.ações contra essa autoridade são merecedoras de acusação, no sentido de colocarem o violador fora da comunidade moral em geral, e tornando lícita (mas não obrigatória) a força retaliatória, defensiva ou punitiva,

A)Consentimento implícito: indivíduos, grupos e Estado têm autoridade para proteger os inocentes da força que não alcança o consentimento.

B)Consentimento explícito: indivíduos, grupos e Estado podem decidir pela vigência de contratos ou criar direitos de assistência social.

C)Justificação do princípio: o princípio do consentimento expressa a circunstância de que a autoridade para resolver disputas morais em uma sociedade pluralista, secular só pode ser obtida a partir do acordo dos participantes, já que não deriva de argumentos racionais ou da crença comum. Portanto, a permissão ou o consentimento é a origem da autoridade, e o respeito ao direito dos participantes de consentir é a condição necessária para a possibilidade de uma comunidade moral. $\bigcirc$ princípio do consentimento proporciona a gramática mínima para o discurso moral secular. É tão inevitável como o interesse das pessoas em acusar ou elogiar com justificação e resolver questões com autoridade moral.

D)A motivação para obedecer ao princípio encontra-se vinculada aos interesses em agir de um modo i) que é justificável a pessoas pacíficas em geral, e ii) que não justificará o uso de força defensiva ou punitiva contra a própria pessoa.

E) Implicações para as políticas públicas: o princípio do consentimento proporciona base moral para políticas públicas destinadas à defesa dos inocentes.

F)Máxima: Não faça aos outros aquilo que eles não fazem consigo mesmos, e faça por eles o que foi contratado para fazer.

G)Princípio do consentimento proporciona a base para aquilo que poderia ser chamado de moralidade de autonomia como respeito mútuo. 


\section{Autonomia: visāo crítica sob o horizonte psicanalítico}

O entendimento de autonomia, enquanto autodeterminação do sujeito, se institui com Kant (como vimos anteriormente) e pode ser definido como a autonomia da razão e independência da vontade; quer dizer, a realização da capacidade racional do homem sem submissão a nenhum dogma, constituindo assim, um exercício de liberdade.

Mesmo já estando hasteada a bandeira do humanismo e do secularismo, o final do século XIX e o século XX assistem ao surgimento de várias críticas à noção kantiana de autonomia. Para SILVA (1998), pelo menos duas observações podem ser feitas a esse respeito: se a compreensão deste conceito se desenvolve em torno do binômio liberdade/normas, que tipo de liberdade poderia ser exercida na conformação à regras do dever? A autonomia da razão, enquanto forma do sujeito moral exercer a liberdade, acaba se constituindo em uma idealização, além da esfera do dever não participar da esfera da liberdade. A segunda é que a moral kantiana acaba sendo um ideal de ação moral e não um critério de discernimento para a experiência moral concreta.

Além desses questionamentos críticos acerca da autonomia, na modernidade, (e como tal, diante da premissa "dar-se as próprias leis"), aponta-se para a tendência de não se levar em conta, quando 
se reflete sobre a conduta ou a ação humana objeto da ética

o enraizamento multidimensional do homem: biológico, psicológico, social, histórico, político, além das variaçōes estruturais e conjunturais que influenciam a vida das pessoas. A necessidade de se ampliar e buscar o aprofundamento sobre essas questões acabou levando muitos estudiosos a repensar o estatuto da autonomia e da ação do sujeito moral frente à decadência do paradigma racionalista. (SEGRE, SILVA \& SCHRAMM 1998).

No final do século XIX, dentre outros, pelos menos dois modelos teóricos de grande importância vêm modificar a maneira de se pensar o sujeito, trazendo conseqüências e novos elementos para o campo da ética: a psicanálise com Sigmund Freud (1856-1939) e a fenomenologia com Edmund Husserl (1859-1938).

A fenomenologia, em linhas gerais, considera que a dimensão da subjetividade não se restringe ao eu pensante, mas se constitui na inter-relação entre as vivências do sujeito, outras subjetividades e o universo das significações e da cultura.

O modelo psicanalítico, partindo da hipótese do inconsciente, rejeita a idéia de subjetividade como consciência lde origem cartesiana) propondo que a instância do sujeito (eu-consciente) dependa de camadas profundas quase inescrutáveis à consciência.

Segundo SEGRE, SILVA \& SCHRAMM (1998, p.18), as concepções freudianas compõem a crítica mais incisiva à idéia de 
consciência como a delimitação clara, segura e imediata do eu. Não somente 'interditam qualquer definição metafísico-substancial da consciência como também fazem depender a instância consciente de camadas profundas que escapam ao nosso acesso e ao controle do pensamento consciente (....) talvez mesmo até de nossa individualidade". Confrontam-se com um abalo conceitual do sujeito "que se pensa com o princípio inquestionável de todos os seus pensamentos e seus atos" _ inevitavelmente isto também se refletirá na maneira de se conceber a autonomia, já que esta é um "exercício de subjetividade".

A pós-modernidade presencia a coesão da subjetividade lou a sua integridade) transformar-se em fragmentação, obscuridade, dispersão. É sob esse panorama que vemos proliferar as novas propostas de moralidade e de remodelação da idéia de autonomia. É nessa direção que apresentaremos a discussão crítica abaixo litem 2.1. e as propostas do item 3 deste capítulo IV.

\subsection{BUSCA DA AUTONOMIA: ENTRE AS EMOCCÕES E A DECISÃO2}

Para SEGRE (1999, p.175) a condição fundamental para se pensar a Ética é que ela seja subjetiva; é algo da ordem da

\footnotetext{
2 . Está baseada nas idéias de Marco Segre, em sua tentativa de reflexão relacionando algumas questões de ética com algumas questões de psicanálise.
} 
interioridade, emerge do que se sente ser a nossa tendência, a nossa inclinação. 'Toda postura ética se embasa, de forma subjacente a qualquer racionalidade, em aspectos afetivos (emoções, sentimentos, crenças, paixões)". Partindo desta concepção de ética o autor adverte, em sua tarefa de repensar a autonomia, que ao priorizar o que "vem de dentro" visa à "desconstrução de toda ordem que já tenha sido estruturada, seja a partir da Lei, da Moral vigente ou da Religião."

Segundo SEGRE \& COHEN (1999) a ética se constitui na composição dos elementos emocional e racional, na medida em que tem que se ouvir "o que o coração diz e o que a cabeça pensa"(p.13). Ou seja: a percepção de interioridade é entremeada pelo pensamento ou reflexão sobre as situações que surgem na vida dos indivíduos.

Para os autores supracitados, uma visão da ética e de conceitos correlatos, baseada em noções psicanalíticas, justifica-se face à limitação do paradigma racionalista tradicional. Ao se compararem as possibilidades de interpretações propostas pela psicanálise com a abordagem filosófica clássica kantiana, temos que a primeira fornece uma dinamicidade e abrangência da concepção de subjetividade proporcionadas pelas instâncias psíquicas (Id, Ego, Superego) que ampliam a maneira de se conceber $\circ$ que seja uma pessoa, e, conseqüentemente de 
interpretar o ato autônomo. Na comparação entre as duas perspectivas teríamos que a kantiana, mesmo contendo como pressuposição a autonomia, essa livre escolha sempre seria necessariamente remetida à razão _ fundamento exterior ao sujeito, vem de "fora".

A perspectiva de base analítica tem como pressuposto que, os valores mesmo sendo eleitos a partir de elementos apreendidos da exterioridade, existe um crivo interior (interação psíquica entre o Ego, Id e Superego, conflitiva geralmente) pelo qual essas informações passam para serem de novo devolvidas _ elaboradas _ao exterior. Essa peculiaridade dinâmica confere uma maior riqueza e propriedade ao desenvolvimento ético, já que "as pessoas não nascem éticas; sua estruturação ética vai ocorrendo juntamente com o seu desenvolvimento", vão construindo sua eticidade. Diło de outro modo: " a humanização traz a ética no seu bojo" (SEGRE \& COHEN, p.13).

A moralidade sendo um sistema fundamental de valores para a elaboração de princípios, regras e normas, é vista sob dois aspectos: o moral e o ético.

O primeiro aspecto é a Moral, abrange a normatização propriamente dita, como os Dez Mandamentos, os Códigos Civil e Penal, etc. Exprimem o poder da autoridade, que tem por finalidade regular os direitos e deveres dos cidadãos ou de uma comunidade 
religiosa _ enquanto autoridades esporadicamente são questionadas, embora se tornem obsoletas, como as cartas jurídicas, no caso dos Códigos. De acordo com a teoria psicanalítica, pode-se interpretar a Moral (enquanto instituição) como correspondendo ao Superego que tem a função de controle e censura. Para a psicanálise, ele se forma a partir da experiência de situações nas quais as representações discursivas externas (fala, palavra) vão sendo vivenciadas e introjetadas. A Moral pressupõe três características:

1)os valores são inquestionáveis;

2)os valores são impositivos;

3)à desobediência das normas corresponde o castigo.

Como exemplos de modalidades moralistas integrantes da vida das pessoas temos a Religião e a Ciência lou qualquer produção do conhecimento). A Religião em si, com seu sistema de valores e de conduta em conformidade inquestionável com um Deus, para SEGRE \& COHEN (1999) é "a pulsão que mais se afasta do desejo humano de liberdade, coibindo a busca pela condição de autonomia" (p.16). O conhecimento, por outro lado, em seu modelo metodológico de racionalização da natureza, acaba enquadrando a visão do mundo a uma interpretação abstrata de exatidão sob propostas teóricas, muitas vezes, restritivas. Em 1623, Galileu escreve "O livro da natureza está escrito em linguagem matemática" (GALILEU 1978, p.119) _ _ e 
esse é o paradigma sob o qual a ciência nasce e se desenvolve, praticamente até o final do século XIX.

À título de ilustração, os autores lembram da polêmica e da diversidade de visões geradas em torno da pergunta: quando começa a vida e quando termina? Respostas são oferecidas pela medicina, como desenvolvimentos científicos, mas também como uma necessidade pragmática de administrar a prática médica, e na maioria das vezes tais respostas são transformadas em cânones. OU seja, há uma tendência em racionalizar os problemas éticos ou que dizem respeito ao homem e à natureza para se ter o controle e a segurança do conhecimento sobre eles.

O segundo aspecto da moralidade é a Ética. Diferencia-se da Moral na medida em que as regras éticas geradas, a partir do trabalho interior do sujeito, pressupõem sua interação com o mundo e sua experiência intersubjetiva, portanto, tais regras autônomas resultam de um sistema de valores individuais baseados primordialmente na afetividade. O conceito de Ética proposto se caracteriza pela vinculação à:

1)percepção dos conflitos;

2)autonomia;

3) coerência.

Tomando os mesmos exemplos anteriores, a Religião e a Ciência, a primeira, do ponto de vista ético, não é autônoma 
podemos dizer que apresenta um caráter mais moralista do que ético ${ }^{3}$. Embora ressalve-se que, considerando a pluralidade necessária presente nas sociedades contemporâneas e, levando-se em conta a terceira característica, para SEGRE \& COHEN (1999, p.18) a pessoa religiosa que optar por sua condição de crente e aceitar as obrigações impostas, mesmo assim ainda estará fazendo uso legítimo de sua condição de autônomo (SEGRE 1999, p.179).

No que diz respeito à Ciência ou à produção do conhecimento 4 é preciso considerar não só seu papel moralista, mas - desenvolvimento ético das pessoas atuantes na produtividade científica e intelectual. Perguntaríamos então: A Ciência é ética? A resposta, de acordo com a perspectiva de nossos proponentes poderia ser: Depende da eticidade de quem faz Ciência.

Poderíamos distinguir dois ângulos nessa resposta. O primeiro diz respeito ao fato de que, como pessoa a condição de eticidade se construiria na dinâmica interna afetiva e na relação com 0 pensamento.

O segundo é que estas pessoas, se em exercício, estão vinculadas a um código profissional que normatiza seus direitos e deveres. Mas essa situação poderá somente conduzi-los a uma

\footnotetext{
${ }^{3}$. Cf. "O Futuro de uma ilusão" Freud faz uma interessante análise (do ponto de vista psicanalítico) do papel da religião para o ser humano. (Os Pensadores - Freud, 1978). 4. Cf. "O Mal-estar na civilização"; Freud discute, aplicando as categorias psicanaliticas, o papel das produçōes humanas intelectuais e artísticas. (Os Pensadores - Freud, 1978).
} 
atitude de obediência às normas, devido a um sentimento de dever ou de medo ao castigo e, nem sempre, a uma postura ética; porque se não souberem "escolher e pensar seus próprios códigos, pensarão de acordo com o código dos outros". A expressão "código de ética" deveria significar muito mais que cumprimento de deveres, apresentação de direitos e punições ao se infringí-los.

Portanto para SEGRE \& COHEN (1999, p.18), "a moral é imposta, a ética é percebida", e o profissional só será ético quando puder entender e compreender o seu código não somente para memorizar os princípios no intuito de precaver-se de infrações. Ser ético profissionalmente, antes pressupõe ser ético pessoalmente, interiormente. Significa que o indivíduo tenha construído sua base pessoal de valores para ter o discernimento da postura correta ou justa, independentemente do que prescrevem as normas, até para que $\circ$ profissional tenha a condição para adotá-las e sugerir mudanças quando estas se apresentarem ultrapassadas.

A partir dos pressupostos da condição de ser ético, nesta persepctiva de base psicanalítica, no que consiste a autonomia com o enfoque na subjetividade?

Para SEGRE (1999, p.177) a autonomia é uma crença "transitando pelo terreno da afetividade, não apenas do pensamento racional"; da mesma maneira que acreditamos em algumas figuras 
culturais para compor os mitos que necessitamos para dar corpo à nossa vida interna e externa. Descarta-se que seja vista como um principio, quer dizer, é rejeitado pelo autor conceber alguma forma de princípio de autonomia, pois a autonomia sendo um dos componentes da condição de eticidade e como tal, da ordem da afetividade, não há como considerá-la um norte ou uma diretriz da ação moral.

A autonomia então, para o autor, enquanto ato moral, é entendida como sendo como "um livre arbitrismo, um exercício da vontade, um self transcendente a todos os condicionamentos virtualmente recebidos" (SEGRE 199, p.177)

A aceitação da existência do inconsciente como parte do aparelho psíquico é considerada um empanamento, um impedimento da capacidade humana de autodeterminação plena _ 'dar-se as próprias leis' de deter exatamente a noção e toda a dimensão de suas escolhas e atos. A partir da hipótese do inconsciente (proposta do modelo psicanalítico) supõe-se que o consciente não seja o responsável exclusivo de nossas decisões; este estaria alimentando o ato consciente por conteúdos inconscientes que de certa maneira seriam as reais motivações da ação (escondidas/ não-percebidas). Segre, de acordo com tais concepções, faz uma relação destas com a idéia cartesiana de 
'realidade do pensamento's para o homem, pois o pensamento, na visão de Descartes, é o que nos dá a conformação do mundo e de nós mesmos. Nessa relação, muito mais criticando do que desconsiderando, SEGRE (1999) interpreta o papel do pensamento, colocando que "tudo o que existe, existe na psiquê das pessoas" (p.178). Quer dizer, o que eu penso é sempre um produto de minha capacidade de sistematização, mas alimentada por um solo anterior que é o conteúdo emocional, instintivo, recalcado, pulsional do inconsciente, cuja emergência o consciente não registra.

SEGRE (1999) não se reconhece conceituando autonomia, mas fornece uma definição que sinaliza para o seu entendimento: "autonomia é percepção de liberdade" (p.178). Mas esclareça-se: para o autor liberdade não é entendida como ausência de parâmetros; a idéia de liberdade envolvida nessa percepção (que "vem de dentro") corresponde às possibilidades e à disposição para a escolha; quer dizer, não há liberdade se a via por onde se vai passar é única. Há que se ter a busca para se concretizar uma situação de escolha, na qual tenha que se visualizar os caminhos, 'prescrutar o coração', pensar e escolher para agir. A busca pela autonomia, assim colocada, atualiza um conflito (vários caminhos) que é a percepção da escolha; na situação de conflito da ação moral, a

\footnotetext{
5 ."Penso, logo existo"; IN: "Discurso do método"; (Os Pensadores - Descartes, 1979).
} 
busca pela própria ética (que "vem de dentro") representará o ato autônomo, por excelência, do sujeito moral.

Nesse sentido, Segre propõe atitude moral como reflexão autônoma e não uma atitude pautada por um princípio de autonomia _ um direcionamento do que se entende 'como ser autônomo'. "Sem a percepção da alternativa, em qualquer tipo de situação, visando à superação do conflito que a possibilidade de escolha provoca, não existiria busca de autonomia" (SEGRE 1999. p. 180).

\section{Consciência: uma tentativa de compreensāo a partir da proposta de Sartre}

Uma reflexão sobre a consciência, ainda que não-exaustiva, se faz necessária na medida em que, Engelhardt, ao definir o conceito de pessoa em sentido estrito como sendo "os seres humanos normais, adultos, racionais e autoconscientes", nos incita a perguntar sobre a consciência. O autor não define o que é ser autoconsciente, apenas dá a entender que é 'ter noção de si' ao caracterizar a pessoa em sentido estrito como agente moral; a pessoa que é capaz de fazer suas escolhas, discernir o bom do mau, saber seus direitos, deveres e responsabilidades é alguém que tem noção de si mesmo, de sua identidade e de sua individualidade. 
No conjunto moralidade secular e estranhos morais, a situação de discordâncias e a possibilidade de solução através da negociação e do acordo tornam evidentes que, em Engelhardt, o conceito de pessoa em sentido estrito é subjacente à idéia de estranhos morais, dado que o exercício pleno da individualidade e da autonomia dos sujeitos envolvidos se manifesta pela escolha, recusa, permissão ao que for contratado.

Como poderíamos pensar o que é consciência para podermos ampliar o entendimento da concepção de pessoa?

Temos a conviç̧ão da extrema complexidade deste tema investigado pela filosofia, psicologia, medicina (para citar apenas algumas áreas), e que as várias hipóteses empíricas ou especulativas a respeito da consciência, a nosso ver, contribuem para a clarificação dessa noção. Afinal, este não é o único tema sobre o qual o conhecimento humano não tem diretrizes seguras; teorias são constructos sobre a realidade, cujas hipóteses podem e são modificadas com a introdução de novos elementos ou variáveis.

A opção pela teoria de Sartre (1905-1980) foi feita por ser o existencialismo uma das correntes de pensamento que maior impacto causou diante do desmonte da idéia central do pensamento clássico _ a coesão do sujeito, a sua identidade com a consciência, pensamento como essência da existência _ na postura crítica em se repensar uma moral do sujeito concreto, da 
situação e da condição humana, da inter-relação 'eu e o outro' e da consciência.

O existencialismo insere-se em um movimento mais amplo denominado Fenomenologia, que surge com Edmund Husserl (18591938). Consiste em uma proposta que pretende ultrapassar a oposição do idealismo e do realismo e afirmar a supremacia da consciência e a presença do mundo, tal como se dá a nós. É através do método descritivo fenomenológico (uma espécie de regressão analítica até o aparecimento ou desvelamento do fenômeno) que propõe efetuar uma crítica de todo modo de se fazer epistemologia (teoria do conhecimento), tanto do subjetivismo idealista quanto do objetivismo positivista. Conforme HUSSERL (1986, p.77), "trata-se de voltar às coisas mesmas", como maneira de conhecê-las"; deixar que elas apareçam à consciência tal como são em sua primordialidade. Mas a consciência em fenomenologia é sempre 'consciência de...', quer dizer, não existe separada da intencionalidade; nesse sentido, para Husserl, é 'fenômeno' (do grego phainomenon, significa 'o que aparece'). De acordo com isso, explica CHAUí (1980),

\footnotetext{
"o fenômeno é consciência, enquanto fluxo temporal de vivências e cuja peculiaridade é a imanência e a capacidade de outorgar significado às coisas exteriores. (....) A fenomenologia é uma descrição da estrutura específica do fenômeno (fluxo imanente de vivências que constitui a consciência) e, como descrição de estrutura da consciência enquanto constituinte, isto é, como condição a priori de possibilidade do conhecimento, o é na medida em que ela, enquanto Consciência Transcendental, constitui as significaçōes e na medida em que conhecer é pura e simplesmente apreender (no nivel empírico) ou constituir (no nivel transcendental) os significados dos acontecimentos naturais e psíquicos." (p. VII)
} 
A crítica consiste em que, para Husserl, o 'fenômeno' supera a categoria clássica dualista de 'essência' e 'aparência', em outros termos, as coisas não são essências dissimuladas pela aparência, que para se chegar ao conhecimento se necessite fazer uma dedução ou indução _ as coisas são tal como aparecem à consciência imediata. Além da consciência intencional, outro pressuposto da análise fenomenológica é o homem-como-ser-no-mundo __ um complexo de relações que interagem entre si e o constituem.

Em sentido geral, todos os fenomenólogos /como Heidegger, Merleau-Ponty e outros) tomam como base esse postulado geral do entendimento da consciência intencional e de sua interface com o mundo e com as coisas, mesmo adaptando-o a sua própria maneira de filosofar; esse, portanto, é o mais importante pressuposto do existencialismo.

Sartre tenta estabelecer uma ontologia fenomenológicab, e parte portanto, da questão do ser, daquilo que é, que existe. Distingue em dois modos fundamentais de ser: o ser em-si (être en-soi) e o ser para-si (être pour-soi).

O ser em-si é, é o que ele é; é entendido como o 'ser das coisas', independente da consciência. Para SARTRE (1943, p.116) ) "o em-si é pleno de si mesmo e não poderia imaginar plenitude mais

\footnotetext{
${ }^{6}$. J. P. Sartre, L'être et le néant - essai d'ontologie phénoménologique, 1943. (usaremos o texto em francês para as citações, mas há uma tradução brasileira: 0 ser e o nada - ensaio de ontologia fenomenológica, Martins Fontes, 2001.
} 
total, adequação mais perfeita do conteúdo ao continente: não existe o menor vazio no ser, a menor fissura por onde se pudesse introduzir o nada" (p.20). Ele é tal como o ser de Parmênides. O ser em-si é o que é, não se relaciona nem consigo mesmo nem com outra coisa de si, não podendo ser submetido à nadificação (néantisation), que só surge com a consciência humana. Segundo BORNHEIM (1971, p.34), o em-si exclui atividade e passividade, possibilidade e necessidade _ estas são noções humanas relativas ao comportamento humano e que pertencem exclusivamente à consciência. "Ele é o que é, é absolutamente idêntico a si mesmo, apresenta-se como uma realidade maciça, permanece totalmente isolado em seu ser e não tem possibilidade de manter qualquer relação com o que não seja ele mesmo, é plena positividade".

O ser para-si é entendido como o 'ser do humano' determinado pela consciência; é o homem. Não existe parentesco algum entre esses dois mundos: o reino das coisas define-se como totalmente outro que não o reino humano. A consciência é para-si, vive voltada para-si; vale dizer que ela se experimenta como relação a si mesma, mas ao mesmo tempo é intencionalidade, e nesse sentido se relaciona ao em-si, não bipartida, mas em uma unidade profunda. Para BORNHEIM (1971, p.38-39) "se a consciência é para-si, opõe-se do outro que não ela, opõe-se ao em-si e, se o em-si é o ser, 
então o para-si, sendo fundamentalmente outro que não em-si, só pode ser o nada". Pode-se dizer que o ser para-si não é, mas existe, ao passo que o em-si é.

O nada é o fundamento do para-si. Analisar a atitude interrogativa do homem para saber é um elemento importante para entender o nada. "Este homem que eu sou, se apreendo tal como é neste momento no mundo, constato que se mantém diante do ser numa atitude interrogativa" (SARTRE 1943, p.38). Toda pergunta, por um sujeito ou por um objeto, supõe um ser que pergunta e um ser que é perguntado. Nessa relação, ambígua, admite-se uma afirmativa e uma negativa; para Sartre coloca-se "por princípio a possibilidade de uma resposta negativa", pois quem pergunta se encontra em uma "não determinação: ele não sabe se a resposta será afirmativa ou negativa", portanto a pergunta encontra a negação do sujeito ou no objeto. Quer dizer, o nada de saber, dado que faz a pergunta. À primeira vista parece que o pressuposto de toda interrogação é o ser e sua afirmação, mas acontece o contrário, pois a pergunta revela o nada - já que ao fazê-la se está imerso no nada e fica-se condicionado ao não-ser. Para SARTRE (1943, p.39) "é também o nãoser que circunscreverá a resposta: o que o ser será se manifestará necessariamente sobre o fundo daquilo que ele não é".

\footnotetext{
7 . Os Pensadores - Pré-socráticos, "Parmênides de Eléia", p.137-192, 1978.
} 
"O homem é o ser pelo qual o nada vem ao mundo" (SARTRE 1943, p.60). Sartre explica isso ao dizer que o ser através do qual o nada chega ao mundo é o ser para cujo ser se coloca a questão do nada de seu ser, e isso é o sentido da existência humana: ela traz em si sua própria negação, o que leva à contradição existencial segundo a qual a "existência é um ser que é o que ele não é, e, que não é o que é". O para-si traz o nada ao mundo e é o mundo que o humaniza.

(...) a existência precede a essência (...) Significa que o homem primeiramente existe, se descobre, surge no mundo; e que só depois se define.(....) o homem não é definivel, porque primeiramente não é nada. (....) Assim nāo há natureza humana, visto que não há Deus para a conceber. (...) que o homem antes de mais nada, é o que se lança para um futuro (....). O homem é, antes de mais nada um projeto que se vive subjetivamente (....) nada existe anteriormente a este projeto. O homem é apenas seu projeto, só existe na medida em que se realiza, ele é tão-somente o conjunto de seus atos (SARTRE 1978, p.6).

Mas isso abre também a existência ao outro de si, entendido como projeto, pois o humano ${ }^{8}$ é um ser que se projeta para o futuro e para além de si mesmo, sendo portanto, também, um ser que ainda não é.

O ser para-si é um vazio, no sentido de ser uma falta a ser completada, por isso se dirige ao em-si; esse vazio de tentar completar-se faz com que se configure a ação, o conhecimento, as possibilidades. É a liberdade fundamental do para-si. Em suma, o

\footnotetext{
${ }^{8}$. Traduzimos "I' homme" do texto francês como humano; o autor não faz distinção de gênero.
} 
humano não é somente o que ele é, mas também sempre o que ele faz de si. Por isso, Sartre diz que o ser do humano consiste na liberdade, pois este humano não pode escapar nunca ao dever de realizar-se a si mesmo, isto é, de fazer de si o que ele é, sendo portanto "condenado a ser livre, condenado porque não se criou a si próprio; e no entanto, livre porque, uma vez lançado ao mundo, é responsável por tudo quanto fizer" (SARTRE 1978, p.9).

Sendo assim, a liberdade é a nadificação do ser para-si através do projetar, visto que Sartre não acredita em nenhum Deus que determine a essência do humano, é este próprio humano que se determina em, e através de sua própria existência, que SARTRE (1978) sintetiza pela frase "A existência precede a essência" (p.6), quer dizer, o humano começa a existir, se encontra nessa existência e se define em seguida. Existir e ser livre portanto coincidem.

Ser livre significa também ser capaz de distanciar-se das coisas do mundo, sobretudo da cadeia causal das coisas e dos eventos: este poder é conferido pela consciência, que é capaz de nadificação, isto é, de fazer aparecer o nada sob o fundo de realidade, desagregando, por exemplo, as determinações e as razões, colocando-se na posição de escolher em qualquer situação. Mas, desta forma, o humano está jogado na situação de plena responsabilidade para consigo mesmo, tendo evidentemente sempre 
a possibilidade de ter uma relação de não-veracidade consigo, a "má-fé".

Escolher ser isso ou aquilo é afirmar ao mesmo tempo o valor do que escolhemos, porque nunca podemos escolher 0 mal, o que escolhemos é sempre o bem, e nada pode ser bom para nós sem que o seja para todos.(....) Assim nossa responsabilidade é muito maior do que poderíamos supor, porque ela envolve toda a humanidade. (...) Angústia é o homem ligado por um compromisso e que se dá conta de que não é apenas aquele que escolhe ser, mas de que é também um legislador pronto a escolher, ao mesmo tempo que a si próprio, a humanidade inteira, não poderia escapar ao sentimento da sua total e profunda responsabilidade. (SARTRE 1978, p.7)

O para-si vazio, oco é pura indeterminação: é portanto radicalmente livre. Essa liberdade, movendo-o através de suas possibilidades, procurará criar-Ihe um conteúdo. Ao experimentar essa liberdade, ao sentir-se como um vazio, o para-si experimenta uma angústia característica: é a angústia da escolha, de ser obrigado a optar por uma dentre todas as possibilidades que se abrem diante de si. Ao procurar uma maneira de se furtar a essa angústia cria uma estrutura de comportamento de não-veracidade que Sartre chamou de má-fé. É a recusa em lidar com a condição de ser livre irremediavelmente, reside na invenção (ou na adoção de) determinismos de qualquer tipo, que colocam no lugar do nada o ser já que o para-si é o não ser, isso é, portanto, uma falsificação de liberdade, má-fé.

Somos separados das coisas por nada, apenas por nossa liberdade; é ela que faz que haja coisas com toda sua indiferença, sua imprevisibilidade e sua adversidade, e que nós sejamos inelutavelmente separados delas, pois é sobre um fundo de 
nadificação que elas aparecem e que se revelam como ligadas umas às outras. (SARTRE 1943, p.591)

"O outro é, por princípio, aquele que me olha" (SARTRE 1943, p. 315). A relação com o outro, a intersubjetividade, aparece em Sartre sob a relação do olhar. Estamos então, diante da questão da relação com o outro de si, ou relação do ser-para-o-outro (être-pour-autrui) que Sartre interpreta como dialética entre o olhar, não reduzido do mero agir do olho, e o ser visto. Ser visto, que o autor concebe como o ser do indivíduo, é desde sempre constituído pela presença dos outros (e que em seu extremo negativo, Sartre sintetiza na peça HuisClos, pela frase "o inferno são os outros").

O ser-para-o outro é uma estrutura essencial do ser para-si porque o vincula ao em-si; é uma síntese do para-si que sou e o em-si que sou para ele _ um terceiro modo de ser profundamente presente na realidade humana, efetuado através do olhar. Se o olhar é de censura torno-me um objeto de reprovação para o outro; se é de aprovação, torno-me objeto de admiração _ de qualquer forma ocorre a petrificação em um em-si. Em face do outro, o homem sempre está em perigo. O ser para-si reduz os humanos aos seus afazeres imediatos, não se colocando, em sua consciência, como aquele que é em-si em seu agir. No entanto, ele é olhado pelo olhar do outro, que o julga. Assim sendo, para conhecer-se o humano 
precisa do outro, que no entanto o mantém como refém (por isso "o inferno são os outros").

A solução encontrada por Sartre é: a posição de refém pode ser superada quando o indivíduo se projeta conscientemente rumo às possibilidades que the dizem respeito_o exercício da liberdade. Então, ele experimenta o seu ser si-mesmo na forma de não ser outro. A compreensão da liberdade e da opção de valores em Sartre aproxima-o, e em certo sentido valida a idéia de moralidade secular e de estranhos morais em Engelhardt; diz SARTRE (1943):
A liberdade é o único fundamento dos valores e nada, absolutamente nada, me justifica ao adotar tal ou tal valor, tal ou tal escala de valores. Enquanto ser pelo qual os valores existem eu sou injustificável. E minha liberdade se angustia de ser o fundamento sem fundamento dos valores (p.76).

A adoção de valores pré-concebidos leva o homem a identificar-se de alguma maneira com o ser. Desse modo, segundo BORHEIM (1971, p.51) o homem que crê, por exemplo, ele se torna um ser-crença, e isso faz com que ele se esqueça de que a consciência é seu fundamento, iludindo-se pelo desejo de ser, que é o desejo de fundamentar-se em algo ou no outro que não ele mesmo (má-fé). $O$ nada é essa distância inaugurada pela consciência e que habita o ser em seu próprio cerne. O Humanismo existencialista dita que ele próprio seja a sua base de valores, que ele se invente a partir do nada ao invés de autodeterminar-se por algo exterior a seu ser, seja a 
família, o Estado, o partido político, a religião, os valores ou qualquer outro tipo de determinismo social, biológico ou psicológico.

O ser da consciência não coincide consigo mesmo em uma adequaçāo plena. (....) A característica da consciência é que ela é uma descompressão do ser. É impossivel, com efeito, definí-la como coincidência consigo própria. Desta mesa, posso dizer que ela é pura e simplesmente esta mesa. Mas de minha crença (por exemplol, nāo me posso limitar a dizer que é crença: minha crença é consciência (de) crença (SARTRE 1943, p.116 e 117).

Segundo BORNHEIM (1971) o homem não é objeto, ele é sujeito. Isso significa que, aqui e agora, a cada instante, é a minha consciência que está 'escolhendo', para mim, aquilo que meu nascimento foi. O modo como sou meu nascimento é eternamente mediado pela consciência, ou seja, pelo nada.

A consciência nada tem de substancial, é uma pura aparência, no sentido de que só existe na medida em que se aparece" (SARTRE 1943, p.23).

\subsection{RESPONSABILIDADE E LIBERDADE}

A idéia de responsabilidade em SARTRE (1978, p.9) está vinculada, de imediato, ao entendimento de liberdade, pois 0 homem "uma vez lançado ao mundo" (p.9) vai construindo sua existência, realizando seu projeto. Essa possibilidade parte do seguinte pressuposto: Deus não existe. SARTRE (1978, p.9) situa o ponto de partida do existencilaismo citando a frase de Dostoiévski: "Se Deus não existisse, tudo seria permitido". É através da hipótese da 
inexistência de Deus, é que decorrem todas as questões que fundam a noção de responsabilidade: liberdade e escolha.

A idéia de existência precedendo a essência, ou seja, a idéia de que não há uma natureza humana, significa que se não há natureza essencial humana, o homem não tem uma trajetória existencial idealizada, direcionada. Ele a constrói através de suas opções, que serão sempre livres, porque desvinculadas do que 'deveria ser', em conformidade com um ideal de homem. Portanto, o homem não somente se concebe, como pode projetar o que quer ser; "é um projeto que se vive subjetivamente, em vez de ser um creme, qualquer coisa podre ou uma couve-flor" (SARTRE 1978, p.6).

Assim, o primeiro esforço do existencialismo é o de pôr todo homem no domínio do que ele é e de lhe atribuir a total responsabilidade de sua existência (SARTRE 1978,p.6)

Na medida em que o homem não é determinado, ele detêm o projeto da sua existência, pois não há a quem atribuir as circunstâncias da vida, não há quem responsabilizar. Nesse sentido a sua responsabilidade é plena. "O homem é livre, o homem é liberdade" (SARTRE1978, p. 9).

Mas a responsabilidade em Sartre não se restringe à opções pessoais, à subjetividade individual, estende-se à todos os homens. "Subjetivismo quer dizer, por um lado, a escolha do sujeito individual por si próprio; e por outro lado, impossibilidade para o homem de superar a subjetividade humana" (SARTRE 1978, p.6). Quando se 
escolhe a si mesmo, porque tem a liberdade de projetar e construir a própria existência, fazer-se, escolhe também a todos os homens; por isso o homem é responsável por aquilo que quer ser e por todos os outros.

Ao escolher o que se quer ser, cria-se uma imagem de homem de acordo com aquilo que opta por ser. É uma afirmação de valores. A questão da escolha está relacionada à uma opção de valores, e o valor sempre é uma preferência pelo bem.

(...) não há dos nossos atos um sequer que, ao criar o homem que desejamos, não se crie ao mesmo tempo uma imagem do homem como julgamos que deve ser. Escolher ser isto ou aquilo é afirmar ao mesmo tempo o valor do que escolhemos, porque nunca podemos escolher o mal, o que escolhemos é sempre o bem, e nada pode ser bom para nós sem que o seja para todos. (....) ao mesmo tempo que construímos a nossa imagem, esta imagem é válida para todos e para a nossa época. Assim nossa responsabilidade é muito maior do que poderíamos supor, porque ela envolve toda a humanidade. (SARTRE 1978, p. 6-7)

Através da imagem que mostramos aos outros é que se percebe a extensão do sentido da responsabilidade sartreana, porque irá exprimir um modelo de existência. SARTRE (1978, p.7) dá o exemplo de alguém que opta por pertencer a um sindicato cristão e não a um sindicato comunista; essa opção indicará que está é a melhor solução para si e para os outros, pois "pretendo ser o representante de todos e, por conseguinte, minha decisão ligou à si a humanidade inteira".

Para SARTRE (1978, p.7) meu projeto implica todos os homens e assim sou "responsável por mim e por todos e crio uma certa imagem 
do homem por mim escolhida; escolhendo-me escolho o homem". Essa profunda responsabilidade gera o que Sartre chama de "angústia", que nada mais é do que o sentimento de compromisso com todos os homens.

Ora,a verdade é que devemos perguntar-nos sempre: que aconteceria se toda gente fizesse o mesmo?" (SARTRE 1978, p.7)

\subsection{SARTRE E ENGELHARDT}

A noção de responsabilidade para Engelhardt expressa-se através da idéia de imputabilidade, quando ele coloca que pessoas em sentido estrito são agentes morais capazes de optar, recusar, fazer acordos e, portanto, imputáveis; quer dizer, podem ser responsabilizados (CAP. III). Para ABBAGNANO (1999, p. 854) "responsabilidade é a possibilidade de prever os efeitos do próprio comportamento e de corrigí-los com base em tal previsão; é diferente de imputabilidade que significa a atribuição de uma ação a um agente, considerado seu causador." Entendemos que haja uma diferença sutil, na medida em que responsabilidade pode ser percebida pela simples intenção de um ato e a possibilidade de prever as suas conseqüências e a imputabilidade pressupōe ação concretizada. Mas ambas, têm como pressuposto a possibilidade de escolha. 
Por outro lado, para traçar um paralelo entre Sartre e Engelhardt é necessário levar em consideração, além da noção de responsabilidade, a idéia de consciência, tal como ambos a concebem.

Em Engelhardt a idéia de autoconsciência como um atributo da pessoa (enquanto "adultos humanos normais", pois as crianças não a possuem e por isso não são pessoas em sentido estrito) significa que a autoconsciência é um processo que vai se desenvolvendo até fase adulta na qual será capaz de manifestar suas escolhas e ser responsáveis por elas.

A idéia sartreana de que o homem é um projeto que se constrói a partir de suas escolhas, porque "está condenado a ser livre" constitui a condição existencial para a manifestação da consciência. Segundo BORHEIM (1971, p.43), "a liberdade e a consciência se circunscrevem reciprocamente. E a consciência sendo um poder nadificador, repele toda e qualquer modalidade de determinismo". Sobre isso diz SARTRE (1943, p.539-540): "escolha e consciência são uma e a mesma coisa; (....) é necessário ser consciente para escolher e é necessário escolher para ser consciente."

Uma objeção a esse tipo de aproximação entre os dois autores sobre o entendimento de consciência poderia ser a seguinte: em Engelhardt a consciência refere-se a um desenvolvimento que se estabelece a partir do nascimento até a idade adulta (pode-se 
lembrar do argumento da potencialidade para as crianças). Nesse sentido, é possivel pressupor a presença de uma essência, de um vira-ser, em termos da consciência _ o que é totalmente contra à visão sartreana. Para Sartre a existência vai sendo construída a partir das escolhas do homem, a partir de sua condição de liberdade.

Mas se focarmos na questão da consciência enquanto capacidade de optar, rejeitar, acordar, etc... em Engelhardt, e, em Sartre, que consciência e escolha são a mesma coisa, é possivel ampliar e clarificar a compreensão da questão da consciência. Consciência, dessa maneira, poderia ser considerada a instância que circunscreve, viabiliza, proporciona, legitima e revela um atributo pessoal sendo manifestada genuinamente através dos atos de vontade e de escolha da pessoa humana.

Portanto, através da idéia de consciência, as noções de imputabilidade em Engelhardt e responsabilidade em Sartre podem ser vistas como equivalentes, pelo fator primordial da escolha. 


\section{V - CONSIDERAÇÕES FINAIS}

O conceito de Pessoa, em Engelhardt, foi o ponto de partida nuclear de nossos estudos, do qual alguns desdobramentos, em termos de reflexão, nos levaram a várias questões correlatas. Engelhardt desenvolve sua teoria sob o paradigma humanista secular, originado na modernidade e caracteriza sua proposta do pluralismo vigente na pós-modernidade.

Ao dividir o conceito de pessoa em dois tipos _ pessoa em sentido estrito e pessoa em sentido social entendemos que Engelhardt procede a essa categorização por razões instrumentais, pois não deixa de se referir a situações concretas de dilemas que no julgamento moral reivindicam algum parâmetro, com respeito a quem cabe a capacidade de decisão de tais situações na área de assistência à saúde. Estes parâmetros possibilitam um dimensionamento e uma compreensão maior do sujeito moral subjacente a qualquer ética, seja ela a moralidade essencial que prevê uma essência para a atitude moral das pessoas _ seja no caso de uma moralidade secular, para a qual não existe uma essência e sim uma diversidade não-sistemática de valores para os atos morais. Nestes dois casos, são válidos os dois conceitos de pessoas, intrumentalmente, para identificar (ou pelo menos para se começar a pensar) a quem é devida a capacidade para 0 
agenciamento moral. Para o autor, agente moral é a pessoa capaz de pensar racionalmente, discernir e escolher de forma consciente seus direitos, deveres, responsabilidades, arbitrar, avaliar, julgar, aderir, rejeitar; para Engelhardt somente as pessoas em sentido estrito são agentes morais.

Por outro lado, as pessoas em sentido social não teriam os requisitos básicos suficientes autoconsciência e racionalidade

para exercer, de maneira plena, a moralidade. São seres humanos que cumprem um papel social de pessoas, sendo-lhes atribuídos dignidade e respeito por isso. De forma que um divisor de águas é colocado com relação ao conceito de pessoa: as que têm noção de seus atos morais e sua conseqüente imputabilidade e são valorizadas como pessoas para o exercício moral, e as que não têm todas essas características, apenas direitos. Instrumentalmente, pode-se dizer que estes conceitos poderiam se constituir em ferramentas para pensar e avaliar vários pressupostos da ética aplicada ou da bioética: princípios como a sacralidade da vida, a qualidade de vida, a beneficência, a autonomia, a eqüidade, a solidariedade, o valor utilitário nas ações em assistência à saúde, as questões de biotecnologia, biomedicina entre outras.

A idéia de estranhos morais, no contexto de uma sociedade democrática e pluralista, a nosso ver, é decorrente do conceito de pessoa em sentido estrito, torna-se a base do edifício da moralidade 
secular no pensamento de Engelhardt. Segundo ela, as pessoas possuem seu sentido moral e ético, mas de maneira diferenciada essa peculiaridade moral é representada pelas idéias de amigos morais e estranhos morais. Amigos morais são pessoas que seguem os mesmos valores e princípios hierárquicos de uma comunidade específica à qual pertencem, aceitos legitimamente pelos adeptos.

As pessoas tornam-se estranhos morais em situações de divergência de valores e princípios morais com os quais necessitam compartilhar uma decisão visando a algum bem-estar no qual todos estão envolvidos. Na irredutibilidade de posições, pois cada um tem seu estilo de vida e posturas morais determinadas, a solução é a negociação. Do ponto de vista teórico. Engelhardt trata essa questão propondo o princípio do consentimento ou de permissão _ uma variante do princípio de autonomia _ mas que não se configura nem como autonomia nem como liberdade, mas como consenso. Permitir ou consentir significa escolher com base em um acordo comum, incluindo o compromisso de responsabilidade diante do que foi acordado. Não prevê adesão e nem exclusão de posturas convictas moralmente _ nesse sentido pode-se dizer que é "procedimental". (ENGELHARDT 2000, p.42)

Nosso entendimento de que a teoria dos estranhos morais incorpora a idéia de pessoa em sentido estrito justifica-se pelo fato de que somente as pessoas constituídas como agentes morais têm a 
capacidade consciente e racional para partilhar decisōes, rejeitar, permitir, consentir e fazer acordos, e sentirem-se responsáveis diante de tais atitudes. Consideramos que as pessoas são centrais, não tanto por sua dignidade ou valor, mas porque podem decidir colaborar ou retirar seu consenso.

Diante dos componentes teóricos do pensamento de Engelhardt, propusemos examinar alguns desdobramentos dessa proposta, relacionados às características do conceito em sentido estrito: a autonomia e a consciência. A autonomia foi tratada do ponto de vista não de seu entendimento clássico, mas de uma forma crítica a ele, já que o próprio Engelhardt rejeita também essa concepção.

A forma de encarar a autonomia a partir de outros elementos paradigmáticos, como alguns conceitos psicanalíticos, traz à tona a questão da multiplicidade necessária para interpretar a ação moral. Ao mesmo tempo coloca a questão da subjetividade vista de uma maneira expandida, que não a linearidade da identidade eu-sujeito e consciência-pensamento. A autonomia mesmo em suas várias formulações, tem como componente básico a possibilidade de opção pelo sujeito, e esta visão crítica colocou justamente que a liberdade de escolha não estaria restrita ao eu consciente, mas ao inconsciente intangivel e irracional entremeado pelas pulsões e pelas emoções. $O$ ato 
autônomo se vê deslocado de seu locus tradicional. A questão da consciência também se tentou tratar deslocada do paradigma clássico da racionalidade: sob a perspectiva fenomenológica existencialista. Sartre propõe pensar a consciência ontologicamente através dos conceitos de ser em-si, ser para si e o complementar serpara-o-outro. A consciência não é um estrutura atribuída ao homem enquanto sua natureza humana. Ela se manifesta na medida em que se volta para o mundo em sua natureza intencional, por isso se constitui em um fluxo de vivências e em um doador de significados; ela é na medida em que se dirige à... , nesse sentido é fenômeno. $O$ homem, o ser para-si, opera a nadificação através de sua consciência, que é o seu modo de estar no mundo e, nesse sentido, é portador de uma liberdade plena e incondicional. Tal situação o torna, a todo momento, um ser que escolhe e se faz, se constrói constantemente, a não ser que, "angustiado" falsifique essa condição e se deixe levar por valores pré-estabelecidos, abrindo mão de sua liberdade.

A questão da responsabilidade em Engelhardt é subjacente à idéia de possibilidade de escolha, como conseqüente das características de pessoa em sentido estrito e de estranhos morais: não há como dar consentimento no consenso, sem que haja 0 compromisso de responder pelos termos negociados. 
Em Sartre, a responsabilidade vem agregada à sua concepção de liberdade humana incondicional que impulsiona $\circ$ "fazer-se", realizada através da escolha: na efetuação de seu projeto de existência, o ser humano escolhe-se e escolhe o outro também, é responsável pela humanidade e a angústia se coloca justamente porque uma escolha repercute para todos os outros humanos.

A idéia de responsabilidade no âmbito da ética aplicada vem sendo largamente discutida; implica em mapear em que sentido o ser humano pode responder por suas atitudes frente a dilemas ou questōes de moralidade. Algumas formulações completam e ampliam as noçōes com que nos deparamos neste estudo, e nesse sentido, e como um esboço para estudos posteriores a partir deste, propomos as noçōes de responsabilidade ôntica de Hans Jonas e o conceito de responsabilidade diacônica de Emmanuel Lévinas.

Em sua definição geral, responsabilidade é "a aceitação das conseqüências naturais dos seus atos, em si mesmo e nos outros; (...) implica reflexão anterior sobre as repercussões de nossos atos. Só é responsável aquele que sabe prever (....). Nesse sentido a responsabilidade prende-se estreitamente à convicção de que o homem tem de ser livre" (LALANDE 1999).

Segundo SCHRAMM \& KOTOW (2001), a ética da responsabilidade ôntica baseia-se em um sentido de "responsabilidade com a totalidade do ser"; quer dizer, expande a 
relação de compromisso entre pessoas para estender-se a um sentido de proteção projetado para o futuro: ações que não sejam de destrutividade para que as expectativas de vida futura no planeta sejam viáveis e dignas. Uma preocupação ética que é reforçada e se torna legítima dia após dia na medida em que as novas tecnologias interferem e modificam não só o modo de viver e as relações humanas, mas também a possibilidade de vida sobre a Terra.

A responsabilidade diacônica corresponde à "responsabilidade com o outro". Diaconia quer dizer o serviço prestado ao próximo; este sentido está relacionado à responsabilidade quanto ao desamparo do outro, que em Lévinas é "assumir incondicionalmente sua proteção".

As duas noções de responsabilidade têm o seguinte em comum: não são formas de exercer o cuidado pura e simplesmente, mas se originam a partir de uma vulnerabilidade que suscita uma forma de amparo que é ofertada livremente pelo agente moral, desencadeada por um senso de aperfeiçoamento moral individual, e por essa razão ambas não são vistas como obrigações. Se compararmos a Engelhardt, a imputabilidade (de quem é agente moral) como obrigação de se responder por seus atos, ou a obrigação de cumprir o acordo entre os estranhos morais, e, com a proposta de Sartre, na qual a responsabilidade decorre de uma liberdade incondicional mas gerando obrigação, as concepções de 
Jonas e Lévinas prevêem uma postura inusitada do ponto de vista moral da obrigação: a responsabilidade com desobrigação, substituindo-se ao senso de proteção.

A idéia de responsabilidade apresenta-se, dessa forma, profícua para além de Sartre e Engelhardt, principalmente considerando o horizonte da bioética e do contexto das ações em saúde, para os quais tal noção me parece imprescindível. 


\section{VI - BIBLIOGRAFIA}

\section{REFERÊNCIAS BIBLIOGRÁFICAS}

Abbagnano N. Dicionário de filosofia. $2^{\circ}$ ed. Trad. Bosi A. São Paulo: Martins Fontes; 1999.

Arendt A. A vida do espirito: o pensar, o querer, o julgar. $3^{\circ}$ ed. Trad. Abranches A, Almeida CAR, Martins H. Rio de Janeiro: Relume Dumará; 1995.

Aristóteles. A polítlca. Trad. Chaves NS. Rio de Janeiro: Ediouro; s/d.

Aristóteles. Ética a Nicômaco. In: Os Pensadores - Aristóteles (II). Trad. Vallandro L. Bornheim G. São Paulo: Abril; 1979.

Beauchamp TL, Childress JF. Principles of biomedical ethics. $3^{\text {rd }}$. ed. New York, Oxford: Oxford Univerity Press; 1989.

Bornheim GA. Sartre. São Paulo: Perspectiva, 1971.

Castiglioni A. Trad. Laclette R. História da medicina. São Paulo: Comp. Ed. Nacional; 1947, 2V.

Chauí M. Introduçāo à história d filosofia: dos pré-socráticos a Aristóteles. São Paulo: Brasiliense; 1994.

Chauí M. Vida e obra. In: Os Pensadores - Husserl. São Paulo: Abril; 1980.

Callahan D. Boethics. In: Reich WT (editor). Encyclopedia of bioethics. $2^{\text {nd. }}$ ed. New York: Simon \& Schuster Macmillan; 1995.

Campbell A. The president's column. In: Garrafa V \& Costa IF (org.). A bioética no século XXI. Brasília: UNB; 2000.

Dennett DC. Conditions of personhood. In: Goodman MF (ed.). What is a person? Clifton, New Jersey: Humana Press; 1998.

Descartes R. Discurso do método. In: Os Pensadores - Descartes. Trad. J Guinsburg e B Prado Jr. Introd. de G-G Granger. São Paulo: Abril Cultural; 1979 (A). 
Descartes R. Meditações. In: Os Pensadores - Descartes. Trad. Guinsburg J \& Prado Jr. B. Introd. de G-G Granger. São Paulo: Abril Cultural; 1979 (B).

Diniz D, Guilhem DB, Garrafa V. Bioethics in Brazil. Bioethics 1999 July; 13(3/4): 245-248.

Engelhardt Jr. HT. Fundamentos da bioética. $2^{\circ}$ ed. 1996. Trad. de JA Ceschin. São Paulo: Loyola; 1998.

Engelhardt Jr. HT. Bioethics and secular humanism: the search for a common morality. London: Trinity Press International; 1991.

Engelhardt Jr. HT. Medicine and the concept of person. In: Goodman MF, editor. What is a person? Clifton, New Jersey: Humana Press; 1988.

Engelhardt Jr. HT. The foundations of christian bioethics. Lisse: Zeitlinger Publishers; 2000.

Freud S. O futuro de uma ilusão. In: Os Pensadores. Trad. de JOA Abreu. Introd. de D Uchoa. São Paulo: Abril Cultural; 1978 (A).

Freud S. O mal-estar na civilização. In: Os Pensadores. Trad. de JOA Abreu. Introd. D Uchoa. São Paulo: Abril Cultural; 1978 (B).

Galileu. O ensaiador. In: Os Pensadores - Bruno, Galileu, Campanella. Trad. Barraco H. São Paulo: Abril; 1978.

Gotffried WL. Novos ensaios sobre o entendimento humano. In: Os Pensadores - Leibniz (II). Trad. Baraúna LJ. São Paulo: Abril; 1980.

Guyton \& Hall. Tratado de fisiologia médica. 10ed. Rio de Janeiro: Guanabara Koogan; 2001.

Heidegger M. Sobre o humanismo. In: Os Pensadores - Heidegger. Trad. Stein E. São Paulo: Abril; 1979.

Heidegger M. Ser e tempo. Petrópolis: Vozes; 1988.

Held V. Moral Pluralism. In: Becker LC (editor). Encyclopedia of ethics. New York \& London: Garland Publishing; 1992, V. 2.

Huisman D. Dicionário de obras filosóficas. São Paulo: Martins Fontes; 2000. 
Husserl E. A idéia da fenomenologia. Trad. Morão A. Lisboa: Ediçōes $70 ; 1986$.

Kant 1. Fundamentação da metafísica dos costumes. In: Os Pensadores - Kant (II). Trad. Quintela P. São Paulo: Abril Cultural; 1980.

Kant I. O que é o esclarecimento? In: Immanuel Kant - Textos seletos. Ed. bilingüe. Trad. de Fernandes FS. Petrópolis: Vozes; 1974.

Kant I. Projet de paix perpétuelle. In: Castillo M. Kant ef l'avenir de la culture. Paris: PUF; 1990.

Lallande A. Vocabulário técnico e crítico da filosofia. Trad. Correia AS, Aguiar MEV, Torres JE, Souza MGS. $3^{\circ} e d$. São Paulo: Martins Fontes; 1999.

Locke J. Ensaio sobre o entendimento humano. Lisboa: Ed. Fundação Calouste Gulbenkian; 1999, $2 \mathrm{~V}$.

Mahowald MB. Person. In: Reich WT (editor). Encyclopedia of bioethics. $2^{\text {nd }}$. ed. New York: Simon \& Schuster Macmillan; 1995.

Merleau-Ponty M. Fenomenologia da percepção. Trad. Ribeiro de Moura CA. São Paulo: Martins Fontes; 1994.

McCullough LB. Foreword. In: Minogue BP (editor). Reading Engelhardt - essays on the thought of $\mathrm{H}$. Tristram Engelhardt Jr. Boston: Kluwer Publishers; 1997.

Mori M. A bioética: sua natureza e história. Trad. Schramm FR. Humanidades 1994; 9 (4): 332-341.

Parmênides. Parmênides de Eléia. In: Os Pensadores - Pré-socráticos. Trad. Kuhnen R. São Paulo: Abril; 1978.

Pessini L \& Barchifontaine CP. Fundamentos de bioética. São Paulo: Paulus; 1996.

Pessini L \& Barchifontaine CP. Problemas atuais de bioética. $4^{\circ}$ ed. São Paulo: Loyola; 1997.

Pascoaes $T$ de. De trinitate. In: Santo Agostinho. Porto: Livraria Civilização; 1945. 
Platão. Parmênides. In: Diálogos. Trad. Nunes CA. Belém: Ed. Universidade Federal do Pará, 1976.

Potter VR. Bioethics: bridge to the future. Englewood Cliffs (NJ): Prentice Hall; 1971.

Potter VR. Global bioethics - building on the Leopold legacy. East Lansing, Mi: Michigan State University Press; 1989.

Santo Agostinho. A cldade de Deus. Petrópolis: Vozes; 1990, 2 V.

Sartre JP. L'être et le nêant - essai d'ontologie phénomenologique. Paris: Gallimard. Coll. Nrf; 1943.

Sartre JP. O ser e o nada - ensaio de ontologia fenomenológica. Trad. Perdigão P. Petrópolis: Vozes; 2001.

Sartre JP. O existencialismo é um humanismo. In: Os Pensadores Sartre. Trad. Ferreira V. São Paulo: Abril; 1978.

Segre M. \& Cohen C. Definição de valores, moral, eticidade e ética. In: Bioética. $2^{\circ} e d$. ampliada. São Paulo: Edusp; 1999.

Segre M. Considerações críticas sobre os princípios da bioética. In: Bioética. $2^{\circ}$ ed. ampliada. São Paulo: Edusp; 1999.

Segre M, Silva FL, Schramm FR. O contexto histórico, semântico e filosófico do princípio de autonomia. Bioética 1998; 6(1):15-23.

Scheler M. Le formalisme en éthique et l'ethique matériale des valeurs. Trad. De Gandillac. Paris: Gallimard; 1955.

Schramm FR. Autonomia difícil. Bloética 1998; 6(1): 27-37.

Schramm FR \& Kottow M. Principios bioéticos en salud pública: limitaciones y propuestas. Cadernos de Saúde Pública 2001 julho/agosto; 17 (4): 949-955.

Silva FL. Da ética filosófica à ética em saúde. In: Iniciação à bioética. Costa SIF, Oselka G, Garrafa V (eds.). Brasilia: Conselho Federal de Medicina; 1998.

Tooley M. Personhood. In: Kuhse $H$ and Singer $P$, editors. A companion to bioethics. Oxford: Blackwell; 1998. 


\section{BIBLIOGRAFIA COMPLEMENTAR}

Annis D. Self-Consciousness and the Right to Life. The Southwestern Journal of Philosophy 1975; 6: 123-128.

Attfield R. On Being Human. Inquiry 1974; 17: 175-192.

Ayer AJ. The Concept of a Person and Other Essays. London: MacMillan; 1964.

Becker LC. Human Being: The Boundaries of the Concept. Philosophy and Public Affairs 1975; 4: 334-358.

Carruthers M. Collins S. Lukes S. (eds.) The Category of the Person: Anthropology, Philosophy, History. Cambridge: Cambridge University Press; 1985.

Chadwick $R$ (editor). Encyclopedia of applied ethics. Callahan D \& Singer $P$ (advisors). San Diego: Academic Press; 1998.

Davis M. Interested Vegetables, Rational Emotions, and Moral Status. Philosophy Research Archives 1986; 11: 531-550.

Davis M. The Moral Status of Dogs, Forests, and Other Persons. Social Theory and Practice 1986; 12: 27-59.

Daniels N. Moral Theory and the Plasticity of Persons. The Monist 1979; 62: 265-287.

Engelhardt Jr. HT. The foundations of bioethics. New York \& Oxford: Oxford University Press; 1986 (1 st.ed.), 1996 (2nd ed.).

Engelhardt Jr TH. \& Spicker S F. Some Persons are Humans, Some Humans are Persons, and the World Is What We Humans Make of It. in Philosophical Medical Ethics - its Nature and Signifcance, Dordrecht, Holland: D. Reidel Publishing Company; 1977.

Engelhardt Jr. HT. The Beginnings of Personhood: Philosophical Considerations. Perkins Journal 1973 Fall; 27: 20-27.

Engelhardt Jr. HT. Personhood, Moral Strangers and The Evil of Abortion. Journal of Medicine and Philosophy 1993 August; 18: 419-421. 
Engelhardt Jr. HT. Foundations, persons and the battle for the millenium. Journal of Medicine and Philosophy Nov.; 88 (13): 387-391.

Engelhardt Jr. HT. Integrity, humaneness and instituitions in secular pluralist societies. Integrity in health care instituitions. Iowa City: University of lowa Press, 1991, 33-43.

Engelhardt Jr HT. The ontology of abortion. Ethlcs 1974 April; 84: 217-34.

Frankena WK. The Ethics of Respect for Persons. Philosophical Topics 1986; 14: 149-167.

French P. Kinds and Persons. Philosophy and Phenomenolocical Research 1983; 44: 241-254

Fleitcher JF. Four Indicators of Humanhood - The Enquiry Matures. Hastings Center Report 1974; 4: 4-7.

Fleitcher JF. Humanhood: Essays in Biomedical Ethics. Buffalo: Prometheus; 1979.

Fleitcher JF. Indicators of Humanhood: A Tentative Profile of Man. Hastings Center Report 1972; 2: 1-4.

Goodman MF. The Moral and Metaphysical Aspects of Personhood. Diss. Michigan State; 1986. Ann Arbor: UMl; 1987.

Goodman MF (ed.). What is a person? Clifton, NJ: Human Press; 1988.

Kant I. Métaphysique des moeurs I, II. Trad. Reanut A. Paris: Flammarion; 1994.

Kuhse $H$. Individulas, humans persons: questions of life and death. Sankt Augustin, Australia: Academia Verlag; 1994.

Kuhse $\mathrm{H}$. The sanctity of life douctrine in medicin - a critique. Oxford: Oxford University Press; 1987.

Kunse H. \& SINGER P. Individuals, humans and persons - the question of moral status, In: Embryo Experimentation. Cambridge: Cambridge University Press, UK; 1993.

Khuse $H$ \& Singer P. (ed.) A Companion to Bioethics, Oxford, Oxford University Press, 1998. 
Langford G. Persons as Necessarily Social. Journal for the Theory of Social Behaviour 1978; 8: 263-283.

Lebrun G. Kant e o fim da metafísica. Trad. Moura CAR. São Paulo: Martins Fontes, 1993.

Lepargneur $\mathrm{H}$. Sobre a bioética ortodoxa de Engelhardt. O Mundo da Saúde 2001 abril/junho; 25 (2): 220-229.

Levin DS. Abortion, Personhood and Vagueness. Journal of Value Inquiry 1985; 19: 197-210.

Lomaski LE. Being a Person - Does it Matter? Philosophical Topics 1981 Winter; 12: 139-152.

MacMurray J. The Form of the Personal. London: Faber; 1957.

Mahold MB. On Humans and Butterflies: A Response to Becker. Philosophy Research Archives 1976; 2: 615-631.

MCCall C. Concepts of person: na analysis of concepts of person, self and human being. London: Avebury Publishing Co, England; 1990.

Melden Al. Rights and Persons. Berkeley: University of California Press; 1977.

Minkus PA. Philosophy of the Person, Oxford: Blackwell; 1960.

Mill JS \& Benthan J. Utilitarism and other essays, London: Penguin Books, 1987.

Mill JS. Utilitarismo, Trad. E. R. Dias, Coimbra, Portugal: AtLântida, 1961.

Moraczewski AS. Human Personhood: A Study in Personalized Biology. Abortion and the Status of the Fetus, Edited by William B. Bondeson, ef al., Dordrecht, Holland: D. Reidel Pub. Co; 1983.

MUñoz DR \& Fortes PAC. O princípio de autonomia e o consentimento livre e esclarecido. In: Iniclação à bioética. Costa SIF, Oselka G, Garrafa V (editores). Brasilia: Conselho Federal de Medicina; 1998.

Padgett JF. Personhood, Morality and Medical Choice. Personalist Forum 1985; 1:99-111. 
Perkoff GT. Toward a Normative Definition of Personhood. Abortion and the Status of the Fetus, Edited by William B. Bondeson, et al., Dordrecht, Holland: D. Reidel Pub. Co: 1983.

Perring C. Degrees of Personhood. The Journal of Medicine and philosophy 1997; 22 (2): 173.

Pucaretti R. The Life of a Person. Contemporary Issues in Bloethics, 2nd ed., Edited by Tom L. Beauchamp and LeRoy Walters. Belmont: Wadsworth; 1982.

Rachels J. Darwin, Species, and Morality. The Monist 1987; 70: 98-113.

Ray AC. Humanity, Personhood, and Abortion. International Philosophical Ouarterly 1985; 25: 233-245.

Rich BA. Postmodern Personhood: a matter of consciousness. Bioethics 1997; 11 (3-4): 206.

Rorty AO. The Identities of persons. Berkeley: University Press; 1976.

Rouanet SP. Dilemas da moral iluminista. Ética. São Paulo: Cia das Letras/Secretaria Municipal de Cultura-SP; 1992.

Schneewind JB.The invention of autonomy - a history of modern moral philosophy. Cambridge: Cambridge University Press; 1998.

Schramm FR. The Dolly case, the Polly drug, and the morality of human cloning. Cadernos de Saúde Pública 1999; 15 (1): 51-63.

Segre M. Reflections on bioethics: consolidation of the principle of autonomy and legal aspects. Cadernos de Saúde Públlca 1999; 15 (1): 91-98.

Singer P. Éfica prática. trad. Camargo JL. São Paulo: Martins Fontes: 1994

Simpson P. The Definition of Person: Boethius Revisited. The New Scholasticism 1988; 62: 210-220.

Singer $P$. The Concept of Moral Standing. Ethics in Hard Times. Caplan A \& Callahan D (editors). New York: Plenum, 1981.

Singer P. Unsanctifying Human Life. Ethical Issues Relating to Life and Death. Ladd J. (editor). New York: Oxford University; 1979. 
Siqueira JE. Hans Jonas e a ética da responsabilidade. $O$ Mundo da Saúde 2001 abril/junho; 25 (2): 220-229.

Taylor C. The Person. The Category of the Person: Anthropology. Philosophy History. Carruthers $M$, Collins $S$, Lukes $S$ (editors). Cambridge: Cambridge University; 1985.

Teichman J. The Definition of Person. Philosophy 1985; 60: 175-186.

Thomas JE. Indicators of Humanhood and the Care of Aging, Chronically III Patients. Clinics in Geriatric Medicine 1986; 2:3-15.

Vlastos G. Human Worth, Merit, and Equality. Moral Concepts. Feinherg J. (editor). Oxford Readings in Philosophy. London: Oxford; 1969.

Weiss R. The Perils of Personhood. Ethics 1978; 89: 66-75. 


\section{ANEXO}

\section{A Produção intelectual de Engelhardt}

A reflexão sobre Ética e Bioética voltada para a área da saúde de Tristram Engelhardt se estende por numerosas publicações contemplando uma variada extensão temática. Em 1997, nos EUA, houve um encontro de especialistas que se dedicaram a discutir esta vasta obra. Resultou em um livro' no qual, além dos artigos das comunicações e discussões, consta uma lista das publicações do autor. Reproduzimos esta coletânea a seguir, complementada por artigos recentes após esse perído.

\section{Livros de autoria:}

The Foundations of Christian bioethics. Lisse: Swets \& Zeitlinger Publishers, 2000.

The Foundations of Bioethics, New York: Oxford University Press, 1986.

The Foundations of Bioethics, $2^{\text {nd }}$. ed. New York: Oxford University Press, 1996.

Fundamentos de Bioética, trad. J. A. Ceschin. São Paulo: Loyola, 1998.

Bioethics and Secular Humanism: The Search for a Common Morality, Philadelphia: Trinity Press International; London: SCM Press, 1991.

1. MINOGUE, B. P., PALMER-FERNÁNDEZ, G., REAGAN, J.(eds.) Reading Engelhardt essays on the thougt of $H$. Tristram Engelhardt, Jr., Boston: Kluwer Academic Publishers, 1997. 
Mind-Body: A Categorial Relation. The Hague, Holland: Martinus Nijhoff, 1973.

Bioethics: Readings and Cases, Baruch A. Brody and H. Tristram Engelhardt, Jr. Englewood Cliffs, N.J.: Prentice-Hall, Inc., 1987.

Artigos e capítulos de livros:

Engelhardt Jr., H. T. and Wildes, K. "In the beginning: the emergence of secular bioethics", in Advances in Bioethics V.5, 1999.

"Critical Care: why there is no global bioethics". Journal of Medicine and Philosophy, 1998.

"Respect for life and the foundations of bioethics" in The ethics of life, eds. D. Noble and J.D. Vincent. Paris: Unesco Publishing, 1997.

"Sanctity of Life and Menschenwürde: Can these Concepts Help Direct the Use of Resources in Critical Care?" in Sanctity of Life and Human Dignity, ed. Kurt Bayertz, Dordrecht: Kluwer, 1996, 201-219.

Engelhardt Jr., H. T. and Cherry, M. J. "From Pagan Greece to Post-Modern Europe", European Philosophy of Medicine and Health Care 4, 1996, 5-12.

"Manners in the Ruins of Community", in Gentility Recalled, ed. Digby Anderson, London: The Social Affairs Unit, 1996, 181 - 194.

"The Search for Untainted Money", American Journal of Respiratory Cell and Molecular Biology 12, February 1995, 123- 124.

"Towards a Christian Bioethics", Christian Bioethics I, March 1995, 1-10.

"Moral Content, Tradition, and Grace: Rethinking the Possibility of a Christian Bioethics", Christian Bioethics I, March 1995, 29-47. 
"Bioethics in Japan and the West: An Investigation in Moral Diversity", in The Dignity of Death, ed. Kazumasa Hoshino, Kyoto: Shibunkaku, 1995, 347-358 (in Japanese).

Engelhardt, Jr., H. T. and Wildes, K. W. S. J "Health and Disease: Philosophical Perspectives" in Encyclopedia of Bioethics, rev. ed., ed. Warren Reich, New York: Macmillan, 1995, vol. 3, 1101-1106.

Engelhardt, Jr., H. T. and Wildes, K. W. S. J. "Philosophy of Medicine", in Encyclopedia of Bloethics, rev. ed., ed. Warren Reich, New York, Macmillan 1995, vol. 4, 1680- 1684.

"Solidarity: Post-Modern Perspectives", Rechtsphilosophische Hefie 4, 1995, 49-63.

Engelhardt, Jr., H. T. and Khushf, G. "Futile Care for the Critically 111 Patient", , Current Opinion in Critlcal Care 1, 1995, 329-333.

"Models of Medical Explanation, or the Passing of Traditional European Medicine", International Prospects of Medical Ethics, eds. Ren-zong Qui, H.M. Sass, Dapu Shi, Xian: People's Education Press of Shangxi, 1995, 9-23 (in Chinese).

"Reproductive Ethics: Conflicts of Vision and Authority," in International Prospects of Medical Ethics, eds. Ren-zong Qiu, H. M. Sass, Dapu Shi, Xian: People's Education Press of Shangxi, 1995, 145-167 (in Chinese).

"Human Reproduction: Conflicts at the Roots of Bioethics and Health Care Policy", in Ethical Aspects of Human Reproduction, eds. Claude Sureau and Françoise Shenfield, Montrouge, France: John Libbey, 1995, 49-60.

"Vecchiaia, eutanasia, e diversità morale: la creazione di opzioni morali nell' assistenza sanitaria", Bioetica, 1995, No. 1: 74-84.

"Christian Bioethics as Non-Ecumenical", Christian Bioethics, September 1995, 182- 199.

"La Bioética: Hito de las humanidades Médicas", H. T. Engelhardt, Jr. and Mark S. Cherry, Cuadernos de Bioética, Sept. 1995, 55-64.

"Bioethics Afler the Failure of Reason", European Philosophy of Medicine and Health Care 3, 1995, special issue on CD-ROM. 
"The Four Principles of Health Care Ethics and Post-Modemity: Why a Libertarian Interpretation is Unavoidable", H. Tristram Engelhardt, Jr. and Kevin Wm. Wildes, S.J., Principles of Health Care Ethics, ed .Raanan Gillon, New York: John Wiley, 1994, 135- 147.

"Human Reproductive Technology: Why All the Moral Fuss?" in The Beginning of Hwnan Life, eds. Fritz Belter and Rober Weir, Dordrecht; Kluwer, 1994, 89- 100.

"Sittlichkeit and Post-Modernity: An Hegelian Reconstruction of the State", Hegel Reconsidered, eds. H. T. Engelhardt, Jr. and Terry Pinkard, Dordrecht: Kluwer, 1994, 211-224.

"Klaus Hartmann and G.W. F. Hegel: A Personal Postscript", Hegel Reconsidered, eds. H. T. Engelhardt, Jr. and Terry Pinkard, Dordrecht: Kluwer, 1994, 225-229.

Engelhardt Jr., H. T. and Wildes, K. W. "Postmodernity and Limits on the Human Body: Libertarianism by Default", , S.J. in Medicine Unbound, eds. R. H. Blank and A.L. Bounicksen, New York: Columbia University Press, $1994,61-71$.

"Consensus: How Much Can We Hope For?" in The Concept of Moral Consensus, ed. Kurt Bayertz, Dordrecht: Kluwer, 1994, 19-40.

"A Skeptical Postscript", in The Concept of Moral Consensus, ed. Kurt Bayertz Dordrecht: Kluwer, 1994, 235-240.

"Attitudes of Critical Care Professionals Concerning Distribution of Intensive Care Resources", Society of Critical Care Medicine Ethics Committee, H. T. Engelhardt Jr., member, Critical Care Medicine 22, Feb. $1994,358-362$.

"Health Care Reform: A Study in Moral Malfeasance", Journal of Medicine and Philosophy 19, October 1994, 501-516.

Engelhardt Jr. H. T. and Wildes, K. W. "The Emergence of Secular Bioethics," S.J. in Principles of Medical Biology, eds. E. E. Bittar and N. Bittar, Greenwich, Conn.: Jai Press, 1994, 1 - 15. 
"Western Bioethics and the Post-Modern World", Journal of Seizon and Life Sciences 4, June 1993, 1 - 12.

"Personhood, Moral Strangers and The Evil of Abortion," Journal of Medicine and Philosophy 18, August 1993, 419-421.

Broadwell, A. W., Boisaubin, E. V., Dunn, J. K. and Engelhardt Jr., H. T. "Advance Directives on Hospital Admission", , Jr., Southern Medical Journal 86, Feb. 1993, 165-168.

Engelhardt, Jr. H. T. and Wildes, K. W. "Il concetto di persona e il fondamento di un'autoritá morale laica", , Bioetica E Persona, ed. Evandro Agazzi, Milano: Franco Angeli, 1993, 13-26.

"National Health Care Policy: The Moral Issues", Bulletin of the American College of Surgeons 78, April 1993, 10-14.

"Ethical Decision Making in Critical Care", in Principles and Practice of Medical Intensive Care, ed. R. W. Carson and M. S. Geheb. Philadelphia: W.B. Saunders 1993, 1724-1730.

"AIDS and HIV Infection: Some Ethical Reflections on a New Disease", in A Study of Applied Ethics, ed. Nobuyuki lida, Chiba University Press, 1993. Vol. 2, 397-401.

Engelhardt Jr., H. T. and Coverdale, J. H "The Psychiatric Admission Index: Deciding When to Admit A Patient", Journal of Clinical Ethics 4, Winter 1993, 315-318.

Engelhardt Jr., H. T. and Coverdale, J. H. "Cases and Social Reality: Making the Decision to Admit", , Journal of Clinical Ethics 4, Winter 1993, 354-356.

"Bioética: laica e religiosa", Bloetica, 1993, 419-421.

"Il corpo in vendita: dilemmi morali della secolarizzazione," in Questioni di bloetica, ed.S. Rodotà, Rome: Laterza and Figli, 1993, 123-138.

"Why a Two-Tier System of Health Care Delivery is Morally Unavoidable", in Rationing America's Medical Care, eds. M. A. Strosberg, J. M. Wiener, and R. Baker, Washington, D.C.: Brookings Institution, 1992, 196-207. 
"The Foundations of Bioethics: Themes of Autonomy and Control", Towards a New Replenishment of Medical Education and Hospital Service, ed. Institute of Medical Humanities, Tokyo: Shin-zau-sha, 1992. 357-374.

"Bioethique: Jusqu'ou faut-il legiferer?" in Bioethique: Jusqu'ou Faut-il Legiferer? Paris: Institut EURO 92, 1992, 3-27.

"Observer Bias: The Emergence of the EtLics of Diagnosis," in The Ethics of Dingnosis, eds. J.L. Peset and D. Gracia, Dordrecht: Kluwer, 1992, 63-71.

"The Search for a Universal System of EtLics", in Ethical Problems in Dialysis and Transplantation, eds. C. M. Kjelistrand and J. B. Dossetor, Dordrecht: Kluwer, 1992, 3-19.

Engelhardt Jr., H. T. and Rie. M. A. "Selling Virtue: Ethics as a Profit Maximizing Strategy in Health Care Delivery", Journal of Health \& Social Policy 4, 1992, 27-35.

"Bioethics in the Post Modern World: Belief and Secularity", Politeia 51, 1992, 1-24.

"Integrity, Humaneness and Institutions in Secular Pluralist Societies", in Integrity in Health Care Institutions, eds. Ruth E. Bulger and Staniey J. Rciser, lowa City, lowa: University of lowa Press, 1991, 33-43.

"Ethics in Critical Care Medicine: Morality in the Face of Finitude", in Critical Care, eds. R. W. Taylor and W. C. Shoemaker, Fullerton, California: Society of Critical Care Medicine, 1991, 103-119.

"Autonomie und Selbstbestimmung: Grundiegende Konzepte der Bioethik in der Psychiatrie", in Ethik in der Psychiatrie, eds. W. Poelinger and W. Wagner, Berlin, Gemlany: SpringerVerlag, 1991, 61-71.

"Medical Ethics for the 21st Century", Journal of American College of Cardiology 18, July 1991, 303-307.

"Natural Theology and Bioethics", in The Philosophy of Charles Hartshorne [the Library of Living Philosophers, Vol. 20], ed. Lewis E. Hahn, La Salle, 111 , Open Court, 1991,159-168. 
"Rights to Health Care: Created, Not Discovered", in Rights to Health Care, eds. T. J. Bole and W. B. Bondeson, Dordrecht, Holland: Kluwer, $1991.103-111$.

"Virtue for Hire: Some Reflections on Free Choice and the Profit Motive in the Delivery of Health Care," in Rights to Health Care, eds. T. J. Bole and W. B. Bondeson, Dordrecht, Holland: Kluwer, 1991, 327-353.

"Is There a Universal System of Ethics or are Ethics Culturc-Specific?" in Organ Replacement Therapy: Ethics, Justice and Commerce, eds. W. Land, J. B. Dossetor, Berlin Heidelberg: Springer-Verlag, 1991, 147-153.

Engelhardt Jr., H. T. and Wm, K., Wildes, S.J. "The Artificial Donation of Human Gametesin", Bailliere's Clinical Obstetrics and Cynnecology 5 , September 1991, 637-658.

"Bioethics" (in Japanese), in Human Being, Science, Religion, ed. Committee for Academic Planning, Kyoto: Ryukoku University, 1991, 353-372.

Engelhardt Jr., H. T. and Bole, T. J. "Entwicklungen der medizinischen Ethik in den USA: Die Verführung durch die Technik und der Irrtum einer Lebenserhaltung um jeden Preis", Arzt und Christ, 36:2, 1990: 113-121.

"The Birth of the Medical Humanities and the Rebith of the Philosophy of Medicine", Journal of Medicine and Philosophy 15, June, 1990, 237-241.

"Some Reflections on the Definition of Death", translated into Japanese as "Shi no Teigi o Megulte," Igaku-Tetsugalu Igaku-Riari (Annais of the Japanese Association for Philosophical and Ethical Research in Medicine) $8,1990,117-128$.

"Taking Pluralism Seriously, or Is the Ethics Manual of the American College of Physicians Unsympathetic to Physicians with Religious Objections to Abortion?" Linacre Quarterly 57, August, 1990, 11 - 14.

"Medical Knowledge and Medical Vision", in The Growth of Medical Knowledge, ed. H. A. ten Have, G. K. Kimsma, and S. F. Spicker, Dordrecht: Kluwer, 1990, 63-71. 
Parmiey, W. W., Schlant, R. C., Crelinsten, G. L., Engelhardt Jr., H. T. et al., "Ethics in Cardiovascular Medicine: Background and General Principles", in Journal of American College of Cardiology 16, July 1990, 7-10.

"Human Nature Technologically Revisited", Social Philosophy \& Policy 8, 1990, 180-191.

"Developing Health Care Policy in Secular Pluralist Societies", in Bio-Ethiek, ed. Ch. Suzanne and J. Stuy, Brussels: VUB Press, 1990, 19-30.

"From Prenatal Scrcening to Foregoing Life-Prolonging Treatment: Justifying Health Care Policy in the 21 st Century", in Blocthics and Medical Economics in the 21st Century, eds. Kazumasa Hoshino and Takao Saito, Tokyo: Sokyusha, Co. Lłd., 1990, 1-23.

"Die Einfuerung von Zugangsbeschrankungen für kosten-intensive lebensrettende medizinische Behandlung," in Sicherhelt und Frelheit, eds. Christoph Sachl3e, H. T. Engelhardt Jr., Frankfurt/Main: Suhrkamp, 1990. 289-312.

"Texas: Messages, Morais, and Myths", Journal of the American Studies Association of Texas 21, October 1990, 33-49.

"Fashioning an Ethic for Life and Death in a Post-Modem Society". Hastings Center Report 19, January/February 1989, 7-9.

"The Use of Anencephalic Tissue for Transplantation", Robert Cefalo and H. T. Engelhardt, Jr., Journal of Medicine and Philosaphy 14, Feb. 1989, 25-43.

"Pain, Suffering, Addiction, and Cancer", in Drag Treatment of Cancer Pain in a Drug-Oriented Society, ed. C. S. Hill, Jr., and W. S. Fields, New York: Raven, 1989, 27-36.

"Taking the Family Seriously: Beyond Best Interest", in Children and Health Care, ed. Loretta Kopelman and John Moskop, Dordrecht: Kluwer, 1989. 231-237.

"Advocacy: Some Reflections on an Ambiguous Temn," in Children and Health Care, ed. Loretta Kopelman and John Moskop, Dordrecht: Kluwer, $1989,317-321$. 
"Foundations: Why They Provide so Littie", Journal of the British Society for Phenomenology 20, May 1989, 67-69.

"Freedom vs. Best Interest: A Conflict at the Roots of Health Care", in Daxis Case: Essays in Medical Ethics and Human Meanings, ed. Lonnie D. Kliever, Dallas, Texas: Southem Methodist University Press, 1989, 79-96.

"The Financial Enforcement of Living Wilis: Putting Teeth into Natural Death Statutes", Michael Rie and H. T. Engelhardt, Jr., Advance Directives in Medicine, eds. Chris Hackler, Ray Moseley, and Dorothy E. Vawter, New York: Praeger Publishers, 1989, 85-92.

"Advance Directives and The Right to Be Lefl Alone", Advance Directive in Medicine, eds. Chris Hackler, Ray Moseley, and Dorothy E. Vawter, New York: Praeger Publishers, 1989, 141 -154.

"Applied Philosophy in the Post-Modem Age: An Augury", Journal of Social Philosophy 20, June 2 1989, 42-48.

"Can Ethics Take Pluralism Seriously?" Hastings Center Report 19 September/October, 1989, 33-34.

"Comments of the Recommendation Regarding Section 504 of the Rehabilitation Act of 1973 and the Child Abuse Amendments of 1984", in A Report of the I./S. Commission of Civil Rights. Medical Discrimination Against Children with Disabilities, September 1989, 158165.

"Information and Authenticity", Journal of Ceneral Internal Medicine 3, January 1988, 91-93.

"Biological Nihilism and Modem Moral and Political Theory", Politics and the Life Sciences 6, February 1988, 202-205.

"The Authority of the Captain", in The Physician as Captain of the Ship, eds. Nancy M. P. King, Larry R. Churchill, and Alan W. Cross, Dordrecht, Holland: D. Reidel, 1988, 67-73.

"Reexamining the Definition of Death and Becoming Clearer about What it is to be Alive." in Death, Beyond Whole-Brain Criteria, ed. Richard $M$. Zaner, Dordrecht: Kluwer, 1988, 9198.

"Diagnosing Well and Treating Prudently", in The Use of Human Beings in Research, ed. S. F. Spicker, et al., Dordrecht: Kluwer, 1988, 123-141. 
"National Health Care Systems: Conflicting Visions," in Health Care Systems, ed. Hans-Martin Sass and Robert Massey, Dordrecht: Kluwer, $1988,3-13$.

Wray, N. et al. \& Engelhardt Jr. H.T. et al. "Withholding Medical Treatment from the Severely Demented Patient", in Archives of Internal Medicine, 148, September 1988, 19801984.

Engelhardt Jr., H. T. \& Rie, M. A. "Morality for the Medical-Industrial Complex", H. T. New England Journal of Medicine 319, October 20, 1988, 1086-1089.

"Foundations, Persons, and the Battie for the Millennium", Journal of Medicine and Philosophy 13, Nov. 1988, 387-391.

"Problems in the Availability of Health Care: Bioethics Reexamined", Unitas 60, June, 1987, 139-150.

Costello, S. \& Engelhardt Jr., H. T. "Licensing, Certification, and the Restraint of Trade: The Creation of Differences Among the Health Care Professions", , Jr., and Mary Ann Gardell in, Bioethics. Readings and Cases, Englewood Cliffs, New Jersey: Prentice-Hall, Inc., 1987, 89-95.

"Infanticide in a Post-Christian Age", in Euthanasia and the Newborn, eds. Richard C. McMillan, H. Tristram Engelhardt, Jr. and S. F. Spicker, Dordrecht, Holland: D. Reidel Publishing Company, 1987, 81 -86.

Gardell, M. A. and Engelhardt Jr., H. T. "The Baby Doe Controversy: An Outline of Some points in Its Development", , Jr., in Euthanasia and the Newborn, eds. Richard C. MCMillan, H. Tristram Engelhardt, Jr., and S. F. Spicker, Dordrecht, Holland: D. Reidel Publishing Company, 1987, 293-299.

"Health Care Institutions", in Health Care Ethics, eds. Donald Van De Veer and Tom Regan, Philadelphia: Temple University Press, 1987, 428-453.

"Having Sex and Making Love: The Search for Morality in Eros", in Sexuality in Medicine, Vol. 2, ed. Earl E. Shelp, Dordrecht, Holland: D. Reidel Publishing Company, 1987, $51-66$.

"Entscheidungsprobleme konkurrierender Interessen von Mutter und Foetus," in Ethische und rechtliche Fragen der Gentechnologie und der 
Reproduktionsmedizin, ed. V. Braun, D. Mieth, and K. Steigleder, Munich, Germany: J. Schweitzer Verlag, 1987, 150-159.

"Gentherapie an menschlichen Keimbahnzellen: Kann und soil die 'schone neve Welt' verhindert warden?" in Etlische und rechtliche Fragen der Gentechnologie und der Reproduktionsmedizin, ed. V. Braun. D. Mieth, and K. Steigleder, Munich, Germany: J. Schweitzer Verlag, 1987, 255-262. ,

"The Bad, the Ugly, and the Unfortunate", in Ethical Dimensions of Geriatric Care, eds. S. F. Spicker, S. R. Ingman, and 1. R. Lawson, Dordrecht: D. Reidel, 19.87, 263-270.

"Persons, Sex, and Contraceptives," in The Contraceptive Ethos, eds. S. F. Spicker, et al., Dordrecht: D. Reidel, 1987, 39-45.

"Human Reproductive Technologies", in Der Stand der bioethischen Discussion in den USA mit besonderer Beruecksichtiguag der Problemstellungen in der Bundesrepublik, ed. HansMartin Sass, Bonn, Westem Gemmany: Studie im Auftrage des Bundesministeriums fuer Forschung und Technologie, 1987, 363-403.

"The Foundations of Bioethics", Revue de Metaphysique et de Morale 92, $1987,387-399$.

"From Philosophy and Medicine to Philosophy of Medicine", The Journal of Medicine and Philosophy 11, February, 1986: 3-8.

"Suicide and the Cancer Patient", in Ca-A Cancer Journal for Clinicians 36. March/April, 1986, 105- 109.

"Intensive Care Units, Scarce Resources, and Conflicting Principles of Justice", H. Tristram Engelhardt, Jr. and Michael A. Rie, Journal of the American Medical Association 255, March 1986, $1159-1164$.

"Ensuring Against Tragedy: The Decision to Treat the Severely Head Injured", in Neurotrauma Treatment, Rehabilitation and Related Issues, eds. Michael E. Miner and Karen A. Wagner, Boston: Butterworths, 1986. 19-26.

"The Social Meanings of Illness", Second Opinion I, July, 1986, 27-39. 
"The Lessons of Finitude", The Western Journal of Medicine 145, August, $1986,187-188$.

"Clinical Complaints and the Ens Morbi", The Journal of Medicine and Philosophy 11, August, 1986, 207-214.

"Humanidades en la Educación Medica Americana", JANO: Medicina Y Humanidades 31, 5-10 November, 1986, 49-50, 53-54, 57-58, 61.

"Editorial Comment", Obstetrics and Gynecology 68, November, 1986, 724-725.

"Bioethik in der pluralistischen Geselischafl", Medizin Mensch Geselischaft 11. December, 1986, 236-241.

"Current Controversies in Obstetrics: Wrongful Life and Forced Fetal Surgical Procedures", American Journal of Obstetrics and Gynecology 151, February 1,1985, 313-318.

"Medical Decisions in a Context of Conflicts," Chest 88, September, 1985. Supplement, 172S174S.

"Moral Tensions in Critical Care Medicine: Absurdities as Indications of Finitude", in Ethics and Critical Care Medicine, eds. John C. Moskop and Loretta Kopelman, Dordrecht, Holland: D. Reidel Publishing Company, $1985,23-33$.

"Hartshorne, Theology, and the Nameless God," in Theology and Bloethics, ed. Earl E. Shelp, Dordrecht, Holland: D. Reidel Publishing Company, 1985, 45-48.

"Looking for God and Finding the Abyss: Bioethics and Natural Theology", in Theology and Bioethics, ed. Earl E. Shel, Dordrecht, Holland: D. Reidel Publishing Company,1985, 79-91.

"Typologies of Disease: Nosologies Revisited", in Logic of Discovery and Diagnosis in Medicine, ed. Kenneth F. Schaffner, Berkeley, California: University of California Press, 1985, 56-71.

"Etica Biomedia: Viejo y Nuevo Panorama", in Retardo Mental, Caracas: AVEPANE, 1985, 399-405. 
"Reason", in Powers That Make Us lluman, ed. Kenneth Vaux, Chicago, lilinois: University of lilinois Press, 1985, 75-91.

"Humanism and the Profession(al)", Journal of Dental Education 49, April $1985,202-206$.

"Physicians, Patients, Health Care Institutions-and the People in Between: Nurses", in Caring, Curing, Coping, eds. Anne H. Bishop and John R. Scudder Jr., Tuscaloosa, Alabama: The University of Alabama Press, 1985. 62-79.

"Persons and Humans: Refashioning Ourselves in a Better Image and Likeness," Zygon: Journal of Religion and Science 19 (September, 1984): 281-295.

"Joseph Margolis, John Rawls, and the Mentally Retarded", in Ethics and Mental Retardation, eds. Loretta Kopelman and John C. Moskop, Dordrecht, Holland: D. Reidel Publishing Company, 1984, 37-42.

"Clinical Problems and the Concept of Disease", in Health, Disease, and Causal Explanations in Medicine, eds. Lennart Nordenfelt and B. Ingemar Lindahl Dordrecht: D. Reidel Publishing Company, 1984, 27-41.

Engelhardt Jr., T. H. \& Erde, E. L. "Philosophy of Medicine", in: A Guide to the Culture of Science, Technology, and Medicine, ed. Paul T. Durbin, New York: Macmillan Free Press, $1980,364-461 ; 2^{\text {nd }}$ ed., 1984, 675-677.

"Comments on Wulff's 'The Causal Basis of the Current Disease Classification'", in Health, Disease, and Causal Explanations in Medicine, eds. Lennart Nordenfelt and B. Ingemar Lindahl, Dordrecht: D. Reidel Publishing Company, 1984, 179-182.

Engelhardt Jr., T.H. \& Spicker, S. F, "Causes, Effects, and Side Effects: Choosing Between the Better and the Best", in Health, Disease, and Causal Explanations in Medicine, eds. Lennart Nordenfelt and B. Ingemar Lindahl Dordrecht, Holland: D. Reidel Publishing Company, 1984, 225-233.

"Allocating Scarce Medical Resources", New England Journal of Medicine 311, July 5,1984, 66-71. 
Davis, B. and Engelhardt Jr., H. T. "Genetic Engineering: Prospects and Recommendations", , Jr., Zygon: Journal of Religion and Science, September, 1984, 277-280.

"Occupational Therapists As Technologists and Custodians of Meaning", in Health Through Occupation: Theory and Practice in Occupational Therapy, ed. Gary Keilhofner, Philadelphia: F. A. Davis Co., 1983, 139-145.

"Viability and the Use of the Fetus," in Abortion and the Status of the Fetus, eds. William B. Bondeson, H. Tristram Engelhardt, Jr., Stuart F. Spicker, and Daniel Winship, Dordrecht, Holland: D. Reidel Publishing Company, 1983, 183-208.

"The Physician-Patient Relationship in a Secular, Pluralist Society", in The Clinical Encounter, ed. Earl Shelp, Dordrecht, Holland: D. Reidel Publishing Company, 1983, 253-266.

"Medizinische Technik und ethische Probleme", in Wandlung con Verantwortungen und Werten in unserer Zeit, Bonn: Deutsche UNESCO Kommission, 1983, 93-105.

"Why New Technology is More Problematic Than Old Technology", in New Knowledge in the Biomedical Sciences, eds. William B. Bondeson, H. Tristram Engelhardt, Jr., Stuart F. Spicker, and Joseph M. White, Jr., Dordrecht, Holland: D. Reidel Publishing Company, 1982, 179-183.

"The Role of Values in the Discovery of Illness", in Contemporary Issues in Bioethics, 2nd edition, eds. Tom Beauchamp and Le Roy Walters, Belmont, California: Wadsworth, 1982, 73-75.

"Bioethics", in Health and Medical Horizons, 1982, eds. D. F. Klein, et. al. NewYork: MacMillan Educational Company, 1982, 186-188.

"Philosophy, Health Care, and Public Policy", Mobius 2, July, 1982, 17-22.

Engelhardt Jr., T. H. \& Malloy, M. "Suicide and Assisting Suicide: A Critique of Legal Sanctions", in Southwestern Law Review 36, November, 1982, 1003-1037.

"Goals of Medical Care, A Reappraisal", in Who Decides. Conflicts of Rights in Health Care, ed. Nora K. Bell, Clifton, NJ: Humana Press, 1982, 49-66. 
"Understanding Faith Traditions in the Context of Health Care: Philosophy as a Guide for the Perplexed", in Health/Medicine and the Faith Traditions, eds. Martin E. Marty and Kenneth L. Vaux, Philadelphia: Fortress Press, 1982, 163- 184.

"Old Problems, New Technologies, and the Changing Values: The Challenge of Biomedicine", in The Philosophical Society of Texas Proceedings, ed. D. H. Winffey, Austin, Texas: The Philosophical Society of Texas, 1982, 9- 8.

"Ethical Issues and Genetic Renal Disease"., in Controversies in Nephrology, eds. George E. Schreiner, James F. Winchester, and Betty F. Mendelson, Washington, D.C.: Georgetown University Press, 1982. 185-200.

"Bioethics in Pluralist Societies", Perspectives in Biology Medicine 26, Autumn, 1982, 64-78.

"Illnesses, Diseases, and Sicknesses", in The Humanity of the III m, ed. Victor Kestenbaum, Knoxville, Tenn: The University of Tennessee Press, 1982, 142-156.

"The Subordination of the Clinic", Value Conflicts in Health Care Delivery, eds. Bart Gruzaiski and Carl Nelson, Cambridge, Mass: Ballinger Publishing Company, 1982, 41-57.

"Physicians and the Community of Physicians: An Account of Collective Responsibilities", The University of Dayton Review 15. Winter, 1981 - 1982. $41-52$.

"Health Care Allocations: Responses to the Unjust, the Unfortunate, and the Undesirable", in Justice and Health Care, ed. Earl Shelp, Dordrecht, Holland: D. F. Reidel Publishing Company, 1981, 121-137.

Engelhardt Jr., T. H. \& McCullough, L. B. "Ethics in Psychiatry", in American Handbook of Psychiatry, Second Edition, Vol. 7, Editor in Chief - Silvan Arieti, with H. Keith and H. Brodie, New York: Basic Books, Inc., 1981, 795-818.

"Relevant Causes: Their Designation in Medicine and Law", in The Law-Medicine Relation. A Philosophical Exploration, Vol. 9, (Philosophy and Medicine Series), eds. Stuart F. Spicker, Joseph M. Mealy, Jr., and H. 
Tristram Engelhardt, Jr., Dordrecht, Holland: D. Reidel Publishing Company, 1981, 123- 127.

"Clinical Judgment", Metamedicine 2, October, 1981, 301 -317.

"Ethical Issues in Diagnosis", Metamedicine I, February, 1980, 39-50.

"Doctoring the Disease, Treating the Complaint, Helping the Patient: Some of the Works of Hygeia and Panacea," Knowing and Valuing, eds. $\mathrm{H}$. Tristram Engelhardt, Jr. and Daniel Callahan, Hastings-on-Hudson: Hastings Center, 1980, 225-249.

"Tractatus Artis Bene Moriendi Vivendique: Choosing Styles of Dying and Living", in Frontiers in Medical Ethics: Applications in a Medical Setting, ed. Virginia Abernethy, Cambridge, Massachusetts: Ballinger Publishing Company, 1980, 9-26.

"Bioethics in the People's Republic of China", Hastings Center Report 10, April, 1980, 7- 10.

"Ethical Issues in Pain Management", in Pain and Society, eds. H. W. Kosterlitz and L. Y. Terenius, Weinheim, West Germany: Chemie, 1980, 483-500.

Engelhardt Jr., H.T. \& H. Mersky. "The Principles of Pain Management Group Report",.. et al., in Pain and Society, eds. H. W. Kosterlitz and L. Y. Terenius, Weinheim, West Germany: Chemie, 1980, 483-500.

"Value Imperialism and Exploitation in Sex Therapy", in Ethical Issues in Sex Therapy and Research, Vol. 11, eds. William H. Masters, Virginia E. Johnson, and Robert C. Kolodny, Boston: Little, Brown, and Company, 1980, 109-137.

"Personal Health Care or Preventive Care: Distributing Scarce Medical Resources", Soundings 63, 3, Fall, 1980, 234-256.

"Philosophy and Medicine: Some Reflections on a Critical Assessment by Caroline Whitbeck", in Research in Philosophy and Technology, ed. P. Durbin, Greenwich, Connecticut: JAI Press, Inc., 1980, 127-130.

"Bioethics", Colliers Encyclopedia, Vol. 4, New York: Macmillan Educational Corporation, 1979, 163- 164. 
Engelhardt Jr., T. H. \& Moskop, J. C. "The Ethics of Suicide: A Secular View", in Sulcide: Theory and Clinical Aspects, ed. L. D. Hancoff, Littleton, Massachusetts: Publishing Sciences Group, 1979, 49-57.

"Is Aging a Disease?" in Life Span: Values and Life-Expanding Technologies, ed. Robert M. Veatch, San Francisco: Harper and Row, 1979, 184- 194.

Engelhardt Jr., T. H. \& McCullough, L. B. "Confidentiality in the Consultation-Liaison Process: Ethical Dimensions and Conflicts", Psychiatric Clinics of North America 2, August, 1979, 403-413.

"Rights to Health Care: A Critical Appraisal," The Journal of Medicine and Philosophy 4, June, 1979, 113-117.

"Mentally Retarded Hepatitis B Carriers in Public Schools", Hastings Center Report 9, December, 1979, 16- 17.

"Philosophical Problems in Biomedicine: Towards a Philosophy of Medicine", Current Research in Philosophy of Sclence, eds. P.D. Asquith and H. E. Kyburg, Jr., East Lansing: Philosophy of Science Association, 1979, 436-449.

"Causal Accounts in Medicine: A Commentary on Stephen Toulmin," reprinted in Changing Values in Medicine, eds. Mark Siegler and Eric Cassell, Frederick, Maryland: University Publications of America, Inc., 1979. 73-81.

"Rights and Responsibilities of Patients and Physicians", in Medical Treatment of the Dying. Moral Issues, eds. Michael D. Bayles and M. H. Dallas, Cambridge, Massachusetts: Schenkman Publishing Company, 1978, 9-28.

"The Doctor's Role in the Evolution of Human Society", in Limits of Medicine, eds. Stewart G. Wolf and Beatrice Bishop Berle, New York: Plenum Press, 1978, 1 -10, 17-21.

"Health and Disease: Philosophical Perspectives", in Encyclopedia of Bioethics, ed. Warren Reich, New York: Macmillan Free Press, 1978, 599-606. 
"Definitions of Death: Where to Draw the Line and Why", in Death and Decision, ed. Ernan McMullin, Boulder, Colorado: Westview Press for the American Association for the Advancement of Science, Selected Symposia Series, No. 18, 1978, 15-34.

Engelhardt Jr., T. H. et al. "To Treat or Not to Treat-The Dilemma", Heart and Lung 7, May/June, 1978, 499-504.

"La Experiencia de la Enfermedad y el Problema del Cuerpo", Quiron 9 Marzo/Junio, 1978, 57-66.

Engelhardt Jr., T. H. \& Erde, E. L. "Philosophy of Medicine" in Encyclopedia of Bloethics, ed. Warren Reich, New York: Macmillan Free Press, 1978, 1049-1054.

Engelhardt Jr., T .H. \& Callahan, D. (eds.), "Moral Autonomy and the Polis: Response to Gerald Dworkin and Gregory Vlastos", in Morals, Science, and Sociality, Hastings-on-Hudson, New York: Hastings Center, $1978,202-214$.

"Taking Risks: Some Background Issues in the Debate Concerning Recombinant DNA Research", Southern California Law Review 51 September, 1978, $1141-1151$.,

"Basic Ethical Principles in the Conduct of Biomedical and Behavioral Research Involving Human Subjects", The Belmont Report, Appendix, Vol. 1. Department of Health, Education, and Welfare, Publication Number 12 , 1978-0013, section 8, 1-45.

"Medicine and the Concept of Person," in Ethical Issues in Death and Dying, eds. Tom L. Beauchamp and Seymour Perlin, Englewood Cliffs, New Jersey: Prentice Hall, Inc., 1978, 271 -284.

"Husserl and the Mind-Brain Relation", in Selected Studies in Phenomenology and Existential Philosophy 6. Phenomenology and the Sciences, eds. D. Inde and R. Zaner, The Hague: Martinus Nijhoff. 1977. $51-70$.

"Ontology and Ontogeny," The Monist 60, January, 1977, 16-28. 
"Is There a Philosophy of Medicine?" Proceedings of the Philosophy of Science Association 1976, Vol. 2, eds. Frederick Suppe and Peter D. Asquith, Ann Arbor, Michigan: Edwards Brothers, 1977, 94- 108.

"Splicing the Brain, Dividing the Soul: Being of Two Minds", Journal of Medicine and Philosophy 2, June, 1977, 89-100.

"Issues and Attitudes in Research and Treatment of Variant Forms of Human Sexual Behavior", in Ethical Issues in Sex Therapy and Research, eds. William H. Masters, Virginia E. Johnson and Robert C. Kolodny, Boston: Little, Brown, 1977, 132-137.

"Errors in Medicine: Let Me Count the Ways", in Knowledge, Value and Bellef, eds. $H$. Tristram Engelhardt, Jr., and Daniel Callahan, Hastings-on-Hudson, New York: Hastings Center, 1977, 310-320.

Engelhardt Jr., T. H. \& Lebacqz, K. "Suicide", in Death, Dying, and Euthanasia, eds. Dennis J. Horan and David Mall, Washington, D.C.: University Publications of America, 1977, 669-705.

"A Study of the Federal Government's Ethical Obligations to Provide Compensation for Persons Injured in the Course of their Participation in Research Supported by Funds Administered by the Secretary of Health, Education, and Welfare", HEW Secretary's Task Force on the Compensation of Injured Research Subjects, Appendix A, Bethesda, Maryland: National Institutes of Health, 1977, 666-672.

Engelhardt Jr., T. H. \& Berger, M. "Observations of a Physician-Patient", Southern Medical Journal 70, August, 1977, 98.

"Defining Occupational Therapy: The Meaning of Therapy and the Virtues of Occupation", The A American Journal of Occupational Therapy November/December, 1977, 122- 125.

Engelhardt Jr., T. H. \& Spicker, S. F. (eds.), "Some Persons are Humans, Some Humans are Persons, and the World Is What We Humans Make of It", in Philosophical Medical Ethics - its Nature and Signifcance, Dordrecht, Holland: D. Reidel Publishing Company, 1977, 183-94.

"On the Bounds of Freedom: From the Treatment of Fetuses to Euthanasia", Connecticut Medicine 40, January, 1976, 51-54, 57. 
"Individuals and Communities, Present and Future: Towards a Morality in a Time of Famine", Soundings 59, Spring, 1976, 70-83.

"Fear of Flying - a commentary on a case history", Hastings Center Report 6, February, 1976, 20.

"Philosophy and Medicine," Journal of Medicine and Philosophy I, March, 1976, 93-100.

Engelhardt Jr., T. H. \& Spicker, S. F (eds.), "Reflections on our Condition: The Geography of Embodiment", in Philosophical Dimensions of the Neuro-Medical Sciences, Dordrecht, Holland: D. Reidel Publishing Company, 1976, 59-68.

Engelhardt Jr., T. H. \& Callahan, D. (eds.), "Human Well-Being and Medicine: Some Basic Value-Judgments in the Biomedical Sciences", in Science, Ethics, and Medicine, Hastings-on-Hudson, New York: Hastings Center, 1976, 120-139.

"The Roots of Science and Ethics", Hastings Center Report 6, June, 1976. 35-38.

"The Meaning of Extraordinary in Extraordinary Care", in Proceedings Conference on Emerging Medical, Moral, and Legal Concerns, eds. A. W. Seimsen and Ira Greifer, Honolulu. Hawaii: Institute of Renal Disease, 1976, 47-62.

"Ideology and Etiology", Journal of Medicine and Philosophy I, September, 1976 256-68.

"Concept of Health", Encyclopedia Britannica; 1977, Medical and Health Annual, Chicago: Encyclopedia Britannica, 1976, 100-08.

"The Dialectic as a Meta-Ontological Method," Hegel-Jabrtuch, 1975 , Koin: Pahl-Rugenstein Verlag, 1976, 424-29.

Engelhardt, T. H. et al. "Elective Abortion: Issues in a Moral Dilemma", in: Continuing Education 3, March, 1975, 20-25.

"The Counsels of Finitude". The Hastings Center Report 5, April, 1975, 29-36. 
Engelhardt Jr., T.H. \& Spicker, S. F., "The Concepts of Health and Disease", in: Evaluation and Explanation in the Biomedical Sclences, Dordrecht, Holland: D. Reidel Publishing Company, 1975, 125-41.

"A Demand to Die - a commentary on a case history". The Hastings Center Report 5, June, 1975, 10, 47.

"Ethical Issues in Aiding the Death of Small Children", in: Benef cent Euthanasia, ed. Marvin Kohl, Buffalo: Prometheus Books, 1975, 180- 192.

"John Hughlings Jackson and the Mind-Body Relation", Bulletin of the History of Medicine 49, Summer, 1975, 137-51.

"Bioethics and the Process of Embodiment", Perspectives in Biology and Medicine 18, Summer, 1975, 486-500.

"The History and Philosophy of Medicine: A Report on a Postgraduate Seminar on the Humanities in Medicine", Clio Medica 19, September, $1975,57-63$.

"The Patient as Person-An Empty Phrase?" Texas Medicine 71, September, 1975, 57-63.

"Defining Death: A Philosophical Problem for Medicine and Law", American Review of Respiratory Disease 112, November, 1975, 587-590.

"The Ontology of Abortion", Ethics 84, April, 1974, 217-34.

"Explanatory Models in Medicine: Facts, Theories, and Valves", Texas Reports on Biology and Medicine 32, Spring, 1974, 225-39.

"Solitude and Sociality", Humanities 10, November, 1974, 227-87.

"The Disease of Masturbation: Values and the Concept of Disease", Bulletin of the History of Medicine 48, Summer, 1974, 234-48.

"The Concept of Bereavement", Death and Ministry, ed. J. D. Bane, A. H. Kutscher, et al., New York: Seabury Press, 1974, 217-220.

"Kantian Knowledge of Other Persons-An Exploration", Akten des 4.Internationalen KantKongresses, Proceedings of the Fourth International Kant-Congress, ed. G. Funke and J. Kopper, Berlin: Walter De Gruyter, 1974, Vol.VII, 2, 576-81. 
"The Beginnings of Personhood: Philosophical Considerations", Perkins Journal 27, Fall, 1973, 20-27.

"Psychotherapy as Meta-ethics", Psychiatry 36, November, 1973, 440-45.

"Viability, Abortion, and the Difference Between a Fetus and an Infant", American Journal of Obstetrics and Gynecology 116, June, 1973, 429-34.

"The Philosophy of Medicine: A New Endeavor", Texas Reports on Biology and Medicine 31, Fall, 1973, 443-52.

\section{Livros editados:}

Hegel Reconsidered. Beyond Metaphysics and the Authoritarian State, eds. H. T. Engelhardt, Jr. and Terry Pinkard, with an introduction by $H$. Tristram Engelhardt Jr., Dordrecht: Kluwor. 1994.

Theological Developments in Bioethics: 1990-1992, eds. B. A. Lustig, B. A. Brody, H. T. Engelhardt, Jr., and L. B. McCullough, Dordrecht: Kluwer, 1993.

Philosophy and Medicine, eds. with a preface by S. F. Spicker and $\mathrm{H}$. Tristram Engelhardt Jr., Tokyo, Japan: Jiku, 1992; appeared in Japanese, ed. Ryuji Ishiwata.

Regional Developments in Bioethics: 1989-1991, eds. B. A. Brody, B. A. Lustig, H. T. Engelhardt, Jr. and L. B. McCullough, Dordrecht: Kluwer, 1992.

Theological Developments in Bioethics: 1988-1990, B. A. Brody, B. A. Lustig, H. T. Engelhardt Jr., and L.B. McCullough, Dordrecht: Kluwer, 1991.

Sicherheit und Freiheit: Zur Ethik des Wohlfabrtsstuates, eds. Christoph Sachl3e and H. Tristram Engelhardt Jr., Frankfurt/M: Suhrkamp, 1990.

She Use of Human Beings in Research, edited by Stuart Spicker, llai Alon, Andre de Vries, and H. Tristram Engelhardt, Jr., Dordrecht: Kluwer, 1988.

The Contraceptive Ethos, edited by Stuart F. Spicker, William B. Bondeson, and H. T. Engelhardt, Jr., Dordrecht, Holland: D. Reidel, 1987. 
Scientific Controversies: A Study in the Resolution and Closure of Disputes Concerning Science and Technology, edited and introduced by $\mathrm{H}$. Tristram Engelhardt, Jr., and Arthur Caplan, New York: Cambridge University Press, 1987.

Euthanasia and the Newborn, edited by Richard C. McMillan, H. Tristram Engelhardt, Jr., and Stuart F. Spicker, Dordrecht, Holland: D. Reidel Publishing Company, 1987.

Abortion and the Status of the Fetus, edited by William B. Bondeson, $H$. Tristram Engelhardt, Jr., Stuart F. Spicker, and Daniel Winship with an introduction by $\mathrm{H}$. Tristram Engelhardt, Jr., Dordrecht, Holland: D. Reidel Publishing Company, 1983. Second printing with updating, 1984.

New Knowledge in the Biomedical Sciences, edited by William $B$. Bondeson; H. Tristram Engelilardt, Jr., Stuart F. Spicker, and Joseph M. White, Jr., with an introduction by $\mathrm{H}$. Tristram Engelhardt, Jr., Dordrecht, Holland: D. Reidel Publishing Company, 1982.

The Roots of Ethics: Science, Religion, and Values, edited by Daniel Callahan and H. Tristram Engelhardt, Jr., New York: Plenum Press, 1981. (A selection of essays from "Volumes Edited" 4, 6, 8 and 11).

Concepts of Health and Disease, edited and introduced by Arthur Caplan, H. Tristram Engelhardt, Jr., and James McCartney, Massachusetts: Addison-Wesley Publishing Company, 1981.

The Law-Medicine Relation: A Philosophical Exploration, edited and introduced by $\mathrm{H}$. Tristram Engelhardt, Jr., Joseph M. Healey, and Stuart F. Spicker, Dordrecht, Holland: D. Reidel Publishing Company, 1981.

Mental Illness: Law and Public Policy, edited by Baruch A. Brody and $H$. Tristram Engelhardt Jr., with an introduction by $\mathrm{H}$. Tristram Engelhardt, Jr., Dordrecht, Holland D. Reidei Publishing Company, 1980.

Knowing and Valuing: The Searchfor Common Roots, edited by $\mathrm{H}$. Tristram Engelhardt, Jr., and Daniel Callahan, with an introduction by $\mathrm{H}$. Tristram Engelhardt, Jr., Hastings-on-Hudson, New York: Hastings Center, 1980.

Clinical Judgment, edited by $H$. Tristram Engelhardt, Jr., Stuart F.Spicker, and Bernard Towers, with an introduction by $\mathrm{H}$. Tristram Engelhardt, Jr., Dordrecht, Holland: D. Reidel Publishing Company, 1979. 
Mental Health: Philosophical Perspectives, edited by $\mathrm{H}$. Tristram Engelhardt, Jr., and Stuart F. Spicker, with an introduction by H. Tristram Engelhardt, Jr., Dordrecht, Holland: D. Reidel Publishing Company, 1978.

Morals, Science, and Sociality, edited by $\mathrm{H}$. Tristram Engelhardt, Jr. and Daniel Callahan, with an introduction by $\mathrm{H}$. Tristram Engelhardt, Jr., Hastings-on-Hudson, New York: Hastings Center, 1978.

Philosophical Medical Ethics: Its Nature and Significance, edited and introduced by Stuart F. Spicker and H. Tristram Engelhardt, Jr., Dordrecht, Holland: D. Reidel Publishing Company, 1977.

Knowledge, Value, and Belief, edited by $H$. Tristram Engelhardt, Jr., and Daniel Callahan, with an introduction by $\mathrm{H}$. Tristram Engelhardt, Jr., Hastings-on-Hudson, New York: Hastings Center, 1977.

Philosophical Dimensions of the Neuro-Medical Sciences, edited and introduced by Stuart F. Spicker and H. Tristram Engelhardt, Jr., Dordrecht, Holland: D. Reidel Publishing Company, 1976.

Science, Ethics, and Medicine, edited by $\mathrm{H}$. Tristram Engelhardt, Jr. and Daniel Callahan, with an introduction by $\mathrm{H}$. Tristram Engelhardt, Jr., Hastings-on-Hudson, New York: Hastings Center, 1976.

Evaluation and Explanation in the Biomedical Sciences, edited and introduced by $\mathrm{H}$. Tristram Engelhardt, Jr. and Stuart F. Spicker, Dordrecht, Holland: D. Reidel Publishing Company, 1975.

The Humanities and Medicine, edited and introduced by Chester R. Burns and H. Tristram Engelhardt, Jr., a special issue of Texas Reports on Biology and Medicine, Spring, 1974. 